SR 199

CRREL

Special Report 199

\title{
FIELD TEST OF A \\ STEAM CONDENSER HEAT SINK CONCEPT
}

W.F. Quinn, H.W.C. Aamot and M.M. Greenberg

January 1974

U.S. ARMY ENGINEER REACTORS GROUP, NUCLEAR POWER DIVISION

OFFICE, CHIEF OF ENGINEERS

BY

CORPS OF ENGINEERS, U.S. ARMY

COLD REGIONS RESEARCH AND ENGINEERING LABORATORY

HANOVER, NEW HAMPSHIRE 
The findings in this report are not to be construed as an official Department of the Army position unless so designated by other authorized documents. 


\title{
FIELD TEST OF A \\ STEAM CONDENSER HEAT SINK CONCEPT
}

\author{
W.F. Quinn, H.W.C. Aamot and M.M. Greenberg
}

\section{January 1974}

\author{
PREPARED FOR \\ U.S. ARMY ENGINEER REACTORS GROUP, NUCLEAR POWER DIVISION \\ OFFICE, CHIEF OF ENGINEERS \\ BY \\ CORPS OF ENGINEERS, U.S. ARMY \\ COLD REGIONS RESEARCH AND ENGINEERING LABORATORY \\ HANOVER, NEW HAMPSHIRE
}




\section{PREF ACE}

This report was prepared by William F. Quinn, Chief, Northern Engineering Research Branch, U.S. Army Cold Regions Research and Engineering Laboratory (USA CRREL); Haldor W.C. Aamot, Mechanical Engineer, Construction Engineering Research Branch, USA CRREL; and Marcus M. Greenberg, Mechanical Engineer, Research and Technology Division, U.S. Army Nuclear Power Group.

The study was performed at the request of the U.S. Army Engineer Reactors Group, Nuclear Power Division, Office, Chief of Engineers.

Investigations were conducted under the general supervision of Kenneth A. Linell, formerly Chief, Experimental Engineering Division, and the direct supervision of Edward F. Lobacz, Chief, Construction Engineering Research Branch, USA CRREL.

Many people participated in the experiment, The authors are especially grateful to Republic Steel Corporation and the staff at the Adirondack Ore Mines under William A. Blomstran, District Manager. Their support of this project was always timely, responsive and cooperative.

Richard Guyer, CRREL Electronics Technician, installed and checked out the temperature-monitoring systems. Four Scientific and Engineering enlisted men from CRREL provided valuable contributions to the project in general and to solving the many problems which are always encountered in putting such a field test together, making it work, and monitoring outputs. The contributions of SP David Karr and SP Joseph Wilhelm are particularly appreciated; they were involved in designing the experiment and assembling the components in the field. They were then most ably assisted by SP Brian Murray and SP Theodore Maffei in monitoring the test 24 hours a day, 7 days a week for 38 days.

The authors appreciate the constructive comments and criticisms of Dr. Richard L. Berg, Frederick E. Crory and Edward F. Lobacz of USA CRREL, and Frederick J. Sanger (formerly of USA CRREL) who reviewed the manuscript. 


\section{CONTENTS}

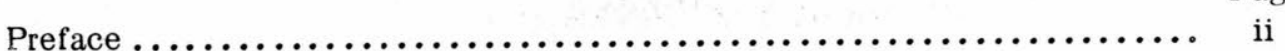

Nomenclature and conversion factors $. \ldots \ldots \ldots \ldots \ldots \ldots \ldots \ldots \ldots, \mathrm{v}$

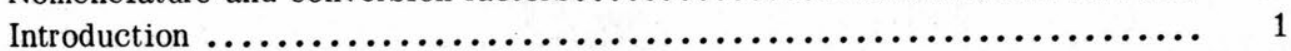

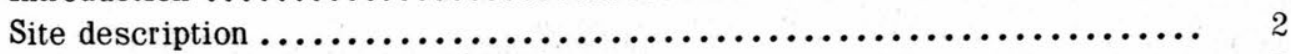

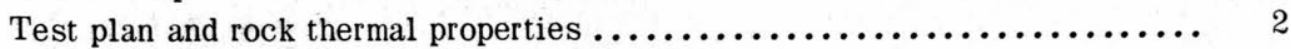

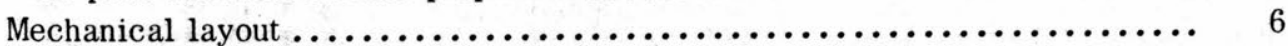

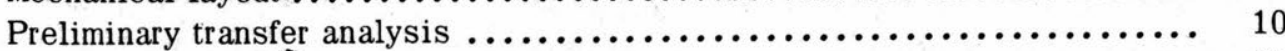

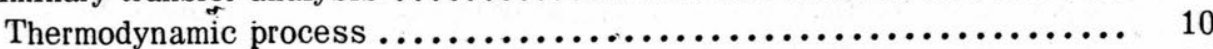

Prediction of air and rock surface temperatures $\ldots \ldots \ldots \ldots \ldots \ldots \ldots . \ldots 11$

Prediction of radial temperature gradients $\ldots \ldots \ldots \ldots \ldots \ldots \ldots \ldots . \ldots . \ldots . \ldots 14$

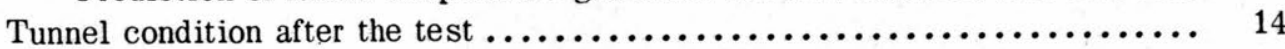

Test results .......................................... 19

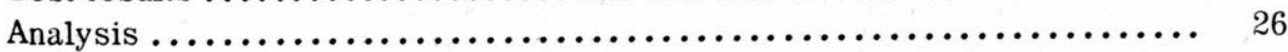

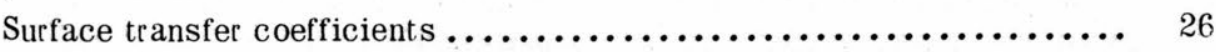

Measured vs predicted surface temperatures.................. 27

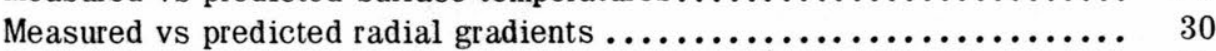

Water-filled vs vapor-filled tunnel $\ldots \ldots \ldots \ldots \ldots \ldots \ldots \ldots \ldots \ldots \ldots . \ldots \ldots$

Conclusions ........................................... 31

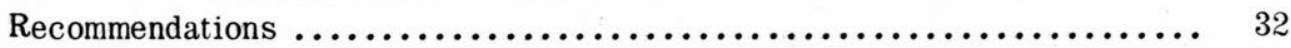

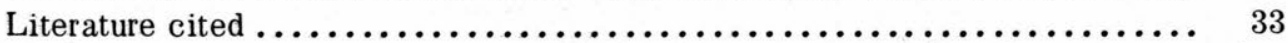

Appendix A: Tabulation of theoretical rock temperatures ............ 35

Figure

\section{ILLUSTRATIONS}

1. Plan view of tunnel used for heat sink test, Mineville, N.Y......... 2

2. Logs of holes cored for thermocouple assemblies ............... 3

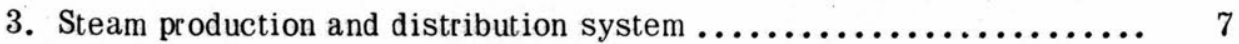

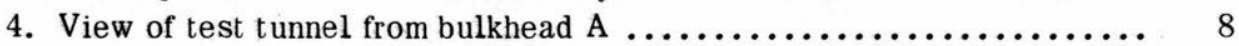

5. View of station 2 looking toward bulkhead B ................. 8

6. Thermocouple assembly ............................... 8

7. Bulkhead A.......................................... 8

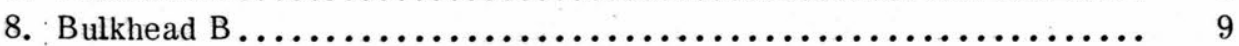

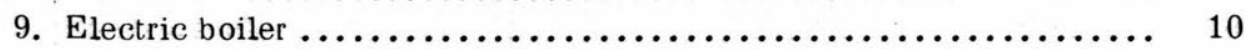

10. Theoretical effect of thermal properties on warmup time........ .12

11. Theoretical effect of tunnel diameter on warmup time............. 12

12. Theoretical relationship between heat flux and warmup time....... 13

13. Theoretical vapor-air and rock surface temperatures vs time........ 13

14. Theoretical radial temperatures at selected times ................ 14

15. View of rock rubble through access door in bulkhead B ........... 15

16. Rock debris adjacent to bulkhead B........................ 15

17. View of tunnel after it was cleared of rubble $\ldots \ldots \ldots \ldots \ldots \ldots \ldots \ldots . . \ldots$

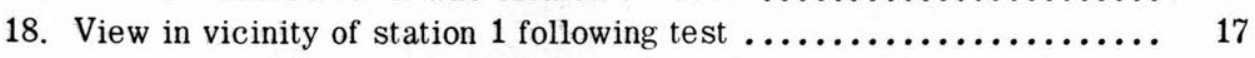

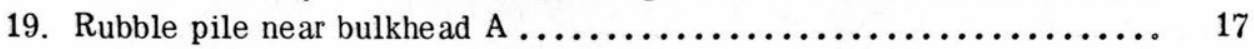

20. View of rock bolts after test ............................ 18

21. Cathedral-like roof developed at station $2 \ldots \ldots \ldots \ldots \ldots \ldots \ldots \ldots . \ldots \ldots$

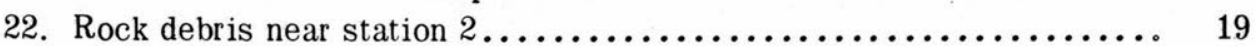


CONTENTS (Cont'd)

\section{Figure}

\section{ILLUSTRATIONS (Cont'd)}

23. Air temperatures vs time at various stations.................. 20

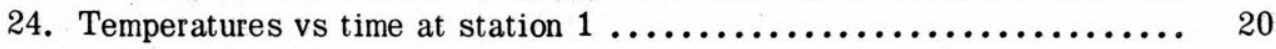

25. Radial distance vs temperature at station 1, 0600, 24 June $1968 \ldots \ldots \ldots 21$

26. Radial distance vs temperature in the west wall, 1200, 22 June 1968 ... 22

27. Temperature difference $\theta$ between air and rock surface........... 22

28. Vapor pressure vs time.............................. 23

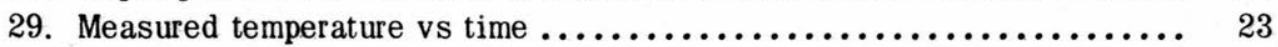

30. Daily fluctuations in feed-water and condensate quantities.......... 24

31. Floor surface and condensate temperatures vs time............... 28

32. Adjusted theoretical surface temperature - time relationship........ 28

33. Comparison of predicted and measured rock temperatures.......... 29

34. Heat flux vs warmup time for vapor-filled and water-filled tunnels..... 30

35. Effect of slight pressure on warmup time extension............. 31

\section{TABLES}

Table

I. Thermal conductivity test results: Mineville rock $\ldots \ldots \ldots \ldots \ldots \ldots, 4$

II. Summary of average thermal conductivities................... 4

III. Apparent specific gravity and density of Mineville rocks........... 5

IV. Chemical analysis of water, parts per million................ 25

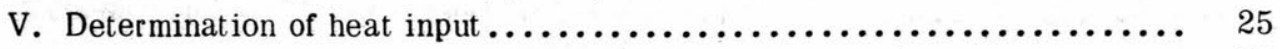

VI. Period of temperature record........................... 26 
NOMENCLATURE AND CONVERSION FACTORS

Symbol

a Radius of cylinder

C $\quad a t / a^{2}$

$h \quad$ Surface heat transfer coefficient

$k \quad$ Thermal conductivity

$r \quad$ Radius

r/a Radius ratio

$t \quad$ Time

$\Delta T \quad$ Temperature difference between initial and current rock surface temperature

$c_{p} \quad$ Specific heat

$\rho \quad$ Density

$\phi \quad$ Heat flux

a Thermal diffusivity

$\theta \quad$ Temperature difference between air vapor and rock surface

\section{Units}

$\mathrm{Ft}$

Dimensionless

$\mathrm{Btu} / \mathrm{ft}^{2} \mathrm{hr}{ }^{\circ} \mathrm{F}$

$\mathrm{Btu} / \mathrm{ft} \mathrm{hr}{ }^{\circ} \mathrm{F}$

Feet

Dimensionless

Hours

${ }^{\circ} \mathrm{F}$

${ }^{5} / 9\left({ }^{\circ} \mathrm{F}-32\right)$

${ }^{\circ} \mathrm{C}$

$\mathrm{Btu} / \mathrm{lb}{ }^{\circ} \mathrm{F}$

4.1868

$\mathrm{kJ} / \mathrm{kg} \mathrm{K}$

$\mathrm{Lb} / \mathrm{ft}^{3}$

16.0185

3.1546

25.806

$5 / 9\left({ }^{\circ} \mathrm{F}-32\right)$

To obtain

m

$\mathrm{W} / \mathrm{m}^{2}{ }^{\circ} \mathrm{C}$

$\mathrm{W} / \mathrm{m}{ }^{\circ} \mathrm{C}$

m

$\mathrm{Btu} / \mathrm{ft}^{2} \mathrm{hr}$

$\mathrm{Ft}^{2} / \mathrm{hr}$

${ }^{\circ} \mathrm{F}$ $\mathrm{kg} / \mathrm{m}^{3}$

$\mathrm{W} / \mathrm{m}^{2}$

$\mathrm{mm}^{2} / \mathrm{sec}$

${ }^{\circ} \mathrm{C}$ 


\title{
FIELD TEST OF A STEAM CONDENSER HEAT SINK CONCEPT
}

\author{
by
}

\author{
W. Quinn, H.W.C. Aamot and M. Greenberg
}

\section{INTRODUCTION}

Power plants may be located deep underground for security purposes; this requires that special consideration be given to the dissipation of waste heat associated with power generation. During most of the plant's operation, heat rejection would probably be accomplished at the surface as is typical for aboveground power plant operations. However, some means for temporary rejection of this waste heat below ground must be available to utilize the full security potential of the buried location. This imposes the requirement that all the waste heat produced by a buried power plant be contained and stored underground for a specified time. A functional and economical heat rejection system is an important design consideration for such installations.

The designer of a hardened underground power plant is presented with several alternatives in his choice of a waste heat sink. The alternatives include water (either at the in situ ground temperature or at some lower temperature provided by mechanical refrigeration), a chemical solution at a depressed temperature below the freezing point of water, an ice-water mixture utilizing the latent heat of fusion, the surrounding ground, or combinations of these materials.

Analytical and laboratory studies have been made of chilled water, chilled brine, and icewater systems..$^{12} 1617$ But in none of these studies has the use of the surrounding medium as the primary heat sink been considered in detail. At the request of the Nuclear Power Division, Office, Chief of Engineers, the U.S. Army Cold Regions Research and Engineering Laboratory conducted a study to determine the feasibility of such a concept. This concept, as developed by $\mathrm{OCE},{ }^{9}$ involved disposing of turbine exhaust steam from a nuclear power plant by discharging it into rock tunnels. The condensate was to be collected and reused in the power cycle after appropriate chemical treatment. The primary advantages of this concept are that it obviates the need to store and maintain large quantities of heat sink substances (water, ice, etc.) underground and also permits the use of tunnels for other than just heat sink purposes. If existing tunnels can be used, the concept becomes economically attractive.

Although the study seemed feasible theoretically, ${ }^{14}$ a field test was required to establish its practicability. (Although a field test of an ice-water heat sink concept was reported in the literature,$^{13}$ no information was available involving the use of rock as a steam condenser.) The field test was conducted to study saturation levels and heat transfer coefficients and to validate the analytical approach for predicting the amount and rate of heat storage by the rock. 


\section{SITE DESCRIPTION}

The site selected for this study was a magnetite mine owned and operated by Republic Steel Corporation in Mineville, New York, approximately 5 miles west of Port Henry. The test was conducted $2250 \mathrm{ft}$ below the gtound surface in a tunnel roughly $10 \mathrm{ft}$ high by $13 \mathrm{ft}$ wide (Fig. 1). The tunnel floor was sloped at a grade of $0.75 \%$ toward the northwest. The choice of a test area within the mine was limited by the general requirement for a tunnel section with a relatively stable roof, located where the test would not interfere with the production mining operation. It was also a test requirement that the face rock be as homogeneous as possible, that faulted zones be avoided, and that power, water and drainage facilities be available. The tunnel had been constructed by the drill, blast and muck method which had caused some fracturing of the face rock.

The drift for the entire length of the test area was in a granitic gneiss made up mainly of quartz and feldspar and sparsely disseminated magnetite; its compressive strength was from 30,000 to 43,000 psi. $^{8}$ The general dip in the location was approximately 25 degrees downward to the left (northeast) and the strike was approximately parallel to the drift. An almost vertical minor fault cut across the drift beyond the end of the test area. The ores and adjacent rock in this drift were possibly Grenville metasediments. ${ }^{2}$

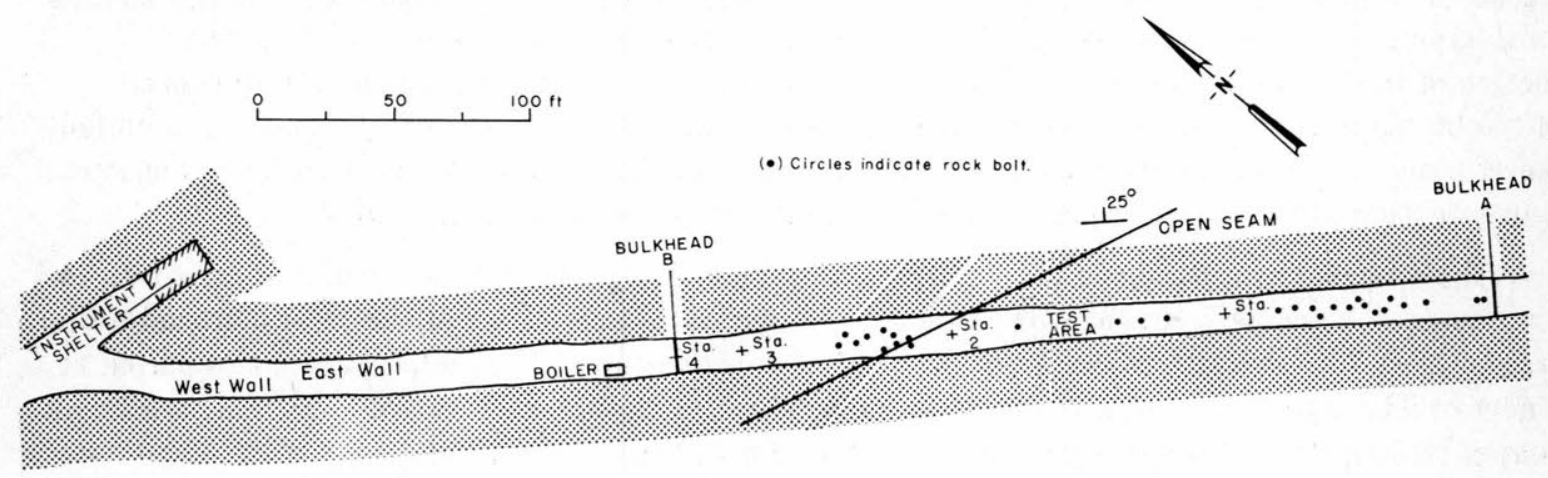

Figure 1. Plan view of tunnel used for heat sink test, Mineville, N.Y.

\section{TEST PLAN AND ROCK THERMAL PROPERTIES}

The overall plan involved the introduction of steam at a constant rate into a 300 -ft section of tunnel until the chamber temperature was within a few degrees of the saturated steam temperature. At that point, the rock can no longer accept heat at the same constant rate and the steam flow (or heat input) must be reduced to avoid an unacceptable increase in the total pressure in the tunnel section. It is essential, in this heat rejection application, that the designer satisfactorily predict the length of time required to reach this critical tunnel temperature condition. The study involved the initial theoretical prediction of this warmup time and a subsequent field test to validate or disprove the prediction.

Four stations within a $300-\mathrm{ft}$ length of tunnel were selected for temperature observations, and thermocouple assemblies were installed to depths of $40 \mathrm{ft}$ in the roof, floor and two side walls at each of the four stations. The position of each station within the test area and the locations of rock bolts are shown in Figure 1. Rock bolts (29 bolts altogether) were installed in the section of roof which were obviously loose. Holes were drilled to accommodate the thermocouple assemblies; a log of the core extracted from each hole is given in Figure 2. Thermal conductivity tests 

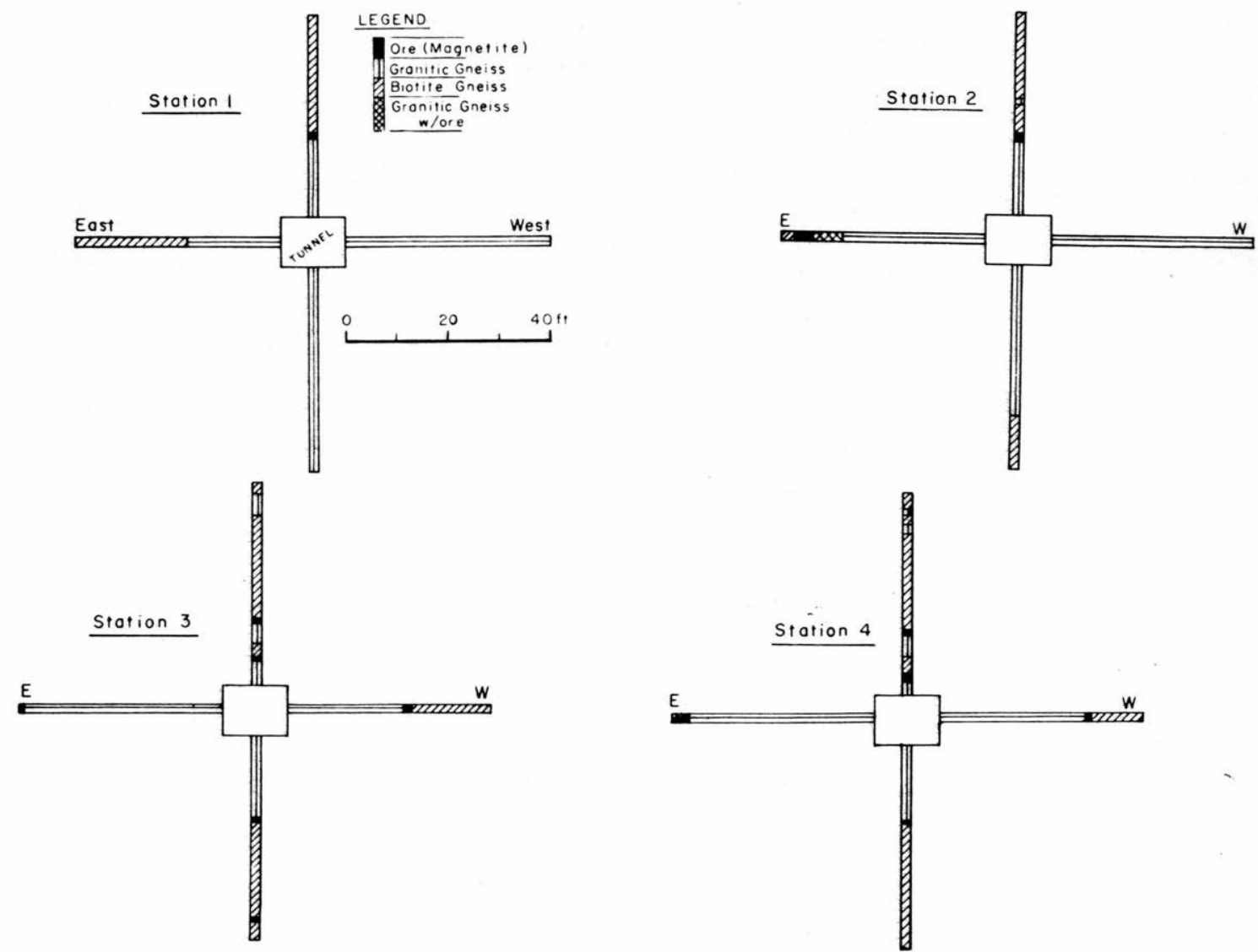

Figure 2. Logs of holes cored for thermocouple assemblies.

were performed on several core samples by Professor Francis Birch of Harvard University. Both vertical and horizontal cores were tested. Thermal conductivities were measured with divided bar systems similar to that described by Birch. ${ }^{1}$ The samples were 0.500 in. thick and either 1.420 or $1.180 \mathrm{in}$. in diameter. In order to determine the effect of moisture, conductivity tests were performed on both air-dry and saturated rock at $104^{\circ} \mathrm{F}$. To establish temperature effects, tests were run on saturated rock at $77^{\circ} \mathrm{F}$. The results of these tests are given in Tables I and II and indicate that (a) the effect of moisture on both the granitic and biotite gneiss was to increase the thermal conductivity by about $2 \%$ above the air-dry conditions, (b) the effect of increasing the temperature from $77^{\circ} \mathrm{F}$ to $104^{\circ} \mathrm{F}$ for the water-saturated condition of the granitic gneiss was to decrease the thermal conductivity by about $3 \%$ (a change in mean temperature had no apparent effect on the biotite gneiss), and (c) the thermal conductivity of granitic gneiss was about $12 \%$ greater in the horizontal direction than in the vertical direction. As previously noted the dip in the area of the test is $25^{\circ}$ from the horizontal. The apparent specific gravities of the Mineville rock are given in Table III.

The 300-ft section of tunnel was sealed off by welded steel bulkheads which were insulated with foamed-in-place polyurethane. Pipes, tracks and ballast were left in place within the test area; however, they were removed at the bulkhead locations. Ditches were excavated on both sides of the track so that the condensed water could return by gravity to the boiler area. The ballast beneath the track varied in thickness from 18 to 24 in. 
Table I. Thermal conductivity test results: Mineville rock.

\begin{tabular}{|c|c|c|c|c|c|c|}
\hline & & & & Thermal & luctivity ( & $\left.f t h r^{\circ} \mathrm{F}\right)$ \\
\hline Rock type & Station & Location & $\begin{array}{l}\text { Depth } \\
\text { (ft-in.) }\end{array}$ & $\begin{array}{c}\text { Dry } \\
\left(104^{\circ} F\right)\end{array}$ & $\begin{array}{r}\text { Water } \\
\left(104^{\circ} \mathrm{F}\right)\end{array}$ & $\begin{array}{l}\text { urated } \\
\left(77^{\circ} F\right)\end{array}$ \\
\hline Granitic gneiss & 1 & Roof & $1-0$ & 2.02 & 2.11 & -- \\
\hline & & & 1.2 & 1.99 & 2.06 & 2.12 \\
\hline & 1 & West wall & 0.10 & 2.30 & 2.41 & -- \\
\hline & & & 1.0 & 2.23 & 2.30 & 2.37 \\
\hline & & & 13.6 & 2.26 & 2.35 & -- \\
\hline & & & 13.8 & 2.13 & 2.22 & 2.31 \\
\hline & 1 & Floor & 2.11 & 1.99 & 2.02 & 2.07 \\
\hline & 2 & Floor & 2.11 & 1.87 & 1.98 & -- \\
\hline & 2 & East wall & 1.0 & 2.22 & 2.33 & -- \\
\hline & & & 1.2 & 2.16 & 2.25 & 2.31 \\
\hline & 3 & West wall & 1.1 & 2.37 & 2.38 & 2.48 \\
\hline & 4 & Roof & $1: 2$ & 1.97 & 2.04 & - \\
\hline & & & $1-4$ & 2.02 & 2.09 & 2.14 \\
\hline Biotite gneiss & 1 & Roof & 17.2 & 1.18 & 1.21 & 1.21 \\
\hline & & & $17-4$ & 1.20 & 1.23 & -- \\
\hline & & & 29.0 & 1.11 & 1.14 & -- \\
\hline & & & 29.2 & 1.04 & 1.05 & 1.05 \\
\hline & 2 & Roof & $18 \cdot 10$ & 1.04 & 1.06 & 1.06 \\
\hline & & & 19.0 & 1.03 & 1.04 & -- \\
\hline & 3 & Roof & 5.8 & 1.21 & 1.228 & -- \\
\hline & & & $6-0$ & 1.21 & 1.238 & 1.24 \\
\hline Ore & 2 & Roof & $15-7$ & 2.80 & 2.90 & 2.95 \\
\hline & & & $15-9$ & 2.73 & 2.83 & -- \\
\hline & 3 & West wall & $23-3$ & 3.19 & 3.24 & -- \\
\hline & & & $23-5$ & 2.97 & 3.02 & - \\
\hline
\end{tabular}

Table II. Summary of average thermal conductivities.

\begin{tabular}{|c|c|c|c|}
\hline \multirow{3}{*}{$\begin{array}{c}\text { Rock type } \\
\text { Granitic gneiss }\end{array}$} & \multirow[b]{2}{*}{ Environment } & \multicolumn{2}{|c|}{ Thermal conductivity $\left(\mathrm{Btu} / \mathrm{ft} \mathrm{hr}^{\circ} \mathrm{F}\right.$} \\
\hline & & Vertical core & Horizontal core \\
\hline & Dry, $104^{\circ} \mathrm{F}$ & $1.97(6)^{*}$ & $2.24(7)$ \\
\hline & Wet, $104^{\circ} \mathrm{F}$ & $2.02(6)$ & $2.32(7)$ \\
\hline & Wet, $77^{\circ} \mathrm{F}$ & $2.11(3)$ & $2.36(4)$ \\
\hline Biotite gneiss & Dry, $104^{\circ} \mathrm{F}$ & $1.12(8)$ & \\
\hline & Wet, $104^{\circ} \mathrm{F}$ & $1.15(8)$ & \\
\hline & Wet, $77^{\circ} \mathrm{F}$ & $1.14(4)$ & \\
\hline & Wet, $104^{\circ} \mathrm{F}$ & $1.14(4)$ & \\
\hline
\end{tabular}

* Number of samples tested. 
Table III. Apparent specific gravity and density of Mineville rocks.

\begin{tabular}{|c|c|c|c|c|c|}
\hline Rock type & Station & Location & $\begin{array}{c}\text { Depth } \\
\text { (ft-in.) }\end{array}$ & $\begin{array}{c}\text { Apparent } \\
\text { spec. grav. }\end{array}$ & $\begin{array}{l}\text { Density } \\
\left(\mathrm{lb} / \mathrm{ft}^{3}\right)\end{array}$ \\
\hline \multirow[t]{5}{*}{ Granitic gneiss } & $\begin{array}{l}1 \\
1\end{array}$ & $\begin{array}{l}\text { Roof } \\
\text { West wall }\end{array}$ & $\begin{array}{l}0-1 \\
0-2\end{array}$ & $\begin{array}{l}2.822 \\
2.871\end{array}$ & $\begin{array}{l}176 \\
179\end{array}$ \\
\hline & 2 & West wall & $1-0$ & 2.895 & 180 \\
\hline & 2 & Floor & $1-0$ & 2.767 & 173 \\
\hline & 3 & West wall & 0.1 & 2.886 & 180 \\
\hline & Avg. & & & 2.848 & 178 \\
\hline \multirow[t]{4}{*}{ Biotite gneiss } & 2 & Roof & $16-8$ & 3.140 & 196 \\
\hline & 3 & Roof & 5.7 & 3.036 & 189 \\
\hline & 4 & Roof & $4-2$ & 3.335 & 209 \\
\hline & Avg. & & & 3.170 & 198 \\
\hline \multirow[t]{6}{*}{ Ore } & 2 & Roof & $15-6$ & 4.933 & 308 \\
\hline & 2 & East wall & $36-3$ & 4.765 & 298 \\
\hline & 2 & Roof & $15 \cdot 8$ & 4.708 & 294 \\
\hline & 3 & Roof & 13.1 & 4.748 & 296 \\
\hline & 3 & Roof & 13.3 & 4.805 & 300 \\
\hline & Avg. & & & 4.791 & 298 \\
\hline
\end{tabular}

Sixteen copper-constantan thermocouple assemblies, each $40 \mathrm{ft}$ long, were installed as four assemblies at each of the four stations. Each assembly consisted of 10 separate thermocouples with spacings of $0,1,2,5,10,15,20,30$ and $40 \mathrm{ft}$ and one in the air $1 \mathrm{in}$. from the surface of the rock. The thermocouples were placed in $17 / 8$-in.-diam $(\mathrm{AX})$ cored holes and were grouted in place with a portland cement slurry. The surface thermocouple was covered with a $1 / 16$ to $1 / 8$ in. thickness of grout. In addition to these thermocouples, several were located in the vicinity of each bulkhead in order to monitor end losses. Thermocouples within $10 \mathrm{ft}$ of the tunnel wall were recorded continuously on multiple point strip chart recorders. The deeper thermocouples were read daily using a manually operated millivolt potentiometer.

Although the concept involved the recovery and reuse of the condensate, it was decided to waste the condensate in this experiment after recording its flow rate and temperature. Samples of feedwater and condensate were taken at various intervals throughout the test to permit the determination of the condensate chemical treatment which would have been necessary under this particular test environment.

Steam was developed by a 296-kw electric boiler operated continuously at approximately 460 volts. An electric boiler was chosen to avoid exhaust gas problems. A constant heat output by the boiler was selected as being a reasonable approximation to the waste heat generated at the essentially constant power level used in operating an underground facility. Steam was distributed within the test area through a two-pipe system. One pipe (pipe $\mathrm{X}$ ) conveyed the steam in a header running the full length of the test area; nineteen vertical riser pipes, spaced at 15-ft intervals, discharged steam in essentially equal quantities throughout the tunnel. The other pipe (pipe $\mathrm{Y}$ ) discharged steam at a single point, $22 \mathrm{ft}$ from bulkhead B.

The original plan was to inject steam through pipe $\mathrm{X}$ until the air temperature was within a few degrees of the saturated steam temperature. At that time the steam was to be injected through 
pipe $\mathrm{Y}$ in order to compare diffusion under the two distribution systems. When a saturated steam condition had been reached, in the test area, it was planned to reduce the constant heat input to approximately three-quarters of its initial rate. This would simulate a reduction in demand on an underground power generating facility and would thereby prolong the effective usefulness of the heat sink.

Consideration was given to providing an initial partial vacuum in the tunnel as usual con- denser practice involves the initial extraction of the non-condensables. Such extraction has a significant effect upon the surface transfer coefficients at the condenser walls. However, for this test, it was decided not to attempt development of an initial vacuum condition. This decision made it unnecessary to design the bulkheads to carry perhaps $8 \mathrm{psi}$ (depending on the vacuum level that could be produced) and to provide reliable seals both at the bulkhead/rock interface and within the rock mass. The test was thus performed at atmospheric pressure with provisions for continuously venting the non-condensables (air). The total atmospheric pressure, determined with an aneroid barometer, varied between 30.9 and 31.1 inches of mercury (15.2 to 15.3 psia) during the experiment.

The following quantities were monitored.

Input: water flow, steam flow, bulkhead pressure, boiler pressure, pipeline pressure and steam quality.

Output: condensate weight and temperature, rock and bulkhead temperatures.

Three photoelastic stress cells were placed at a depth of $2 \mathrm{ft}$ in the rock in the vicinity of Station 3; the intention was to obtain thermal stress readings upon completion of the test.

\section{MECHANICAL LAYOUT}

A complete description of the mechanical system and its performance has been given by Karr et al. ${ }^{10}$ A flow diagram depicting the steam supply, condensate return and vent systems is given in Figure 3a. The pipe $X$ distribution system is shown in Figure 3b. The spacing between the roof and the riser pipe was maintained constant to provide a uniform distribution of steam throughout the tunnel cross section.

An overall view of the test area is given in Figure 4; this photo was taken from bulkhead A looking toward bulkhead B. Note the condensate trap at the terminus of the pipe $\mathrm{X}$ header (lower right). The header was sized for a constant velocity of about $8000 \mathrm{ft} / \mathrm{min}$ which is reasonable for processed steam. The header consisted of three sections: $100 \mathrm{ft}$ of 2 -in. schedule $40,100 \mathrm{ft}$ of $1 \frac{1}{2}$-in. schedule 40 and $85 \mathrm{ft}$ of 1 -in. schedule 80 . The system was initially balanced volumetrically using compressed air available at the site. The use of air avoided upsetting the existing thermal regime in the test area and also provided a less hazardous environment in which to work. Figure 5 shows the condition of the tunnel before the test in the vicinity of station 2 , looking toward bulkhead B. Thermocouple assemblies may be seen on the roof, floor and two side walls. A closeup view of the thermocouple assembly in the west wall at station 3 is shown in Figure 6 . The hole at the lower left was drilled to hold a stress meter. A photograph of bulkhead A taken from outside the test area is shown in Figure 7; it shows the insulation and thermocouple wires.

Each bulkhead was fabricated from $3 / 8$ in. steel plate. The bulkhead frame consisted of $1 \frac{1}{2}$-in. steel angles welded to $1 \frac{1}{8}$ in. steel rods installed in the rock in the roof, floor and walls. To provide a tight seal between the rock surface and the steel plate, the plate was cut on the site to conform to within about $1 \mathrm{in}$. of the irregular rock surface. Wire mesh was fitted in the joints and welded in place on each side of the bulkhead and portland cement mortar was then placed in the joint. Foamed-in-place insulation acted as both a thermal barrier and a vapor seal. The access ports were closed by means of a bolted, insulated $3 / 8$ in. steel plate. 


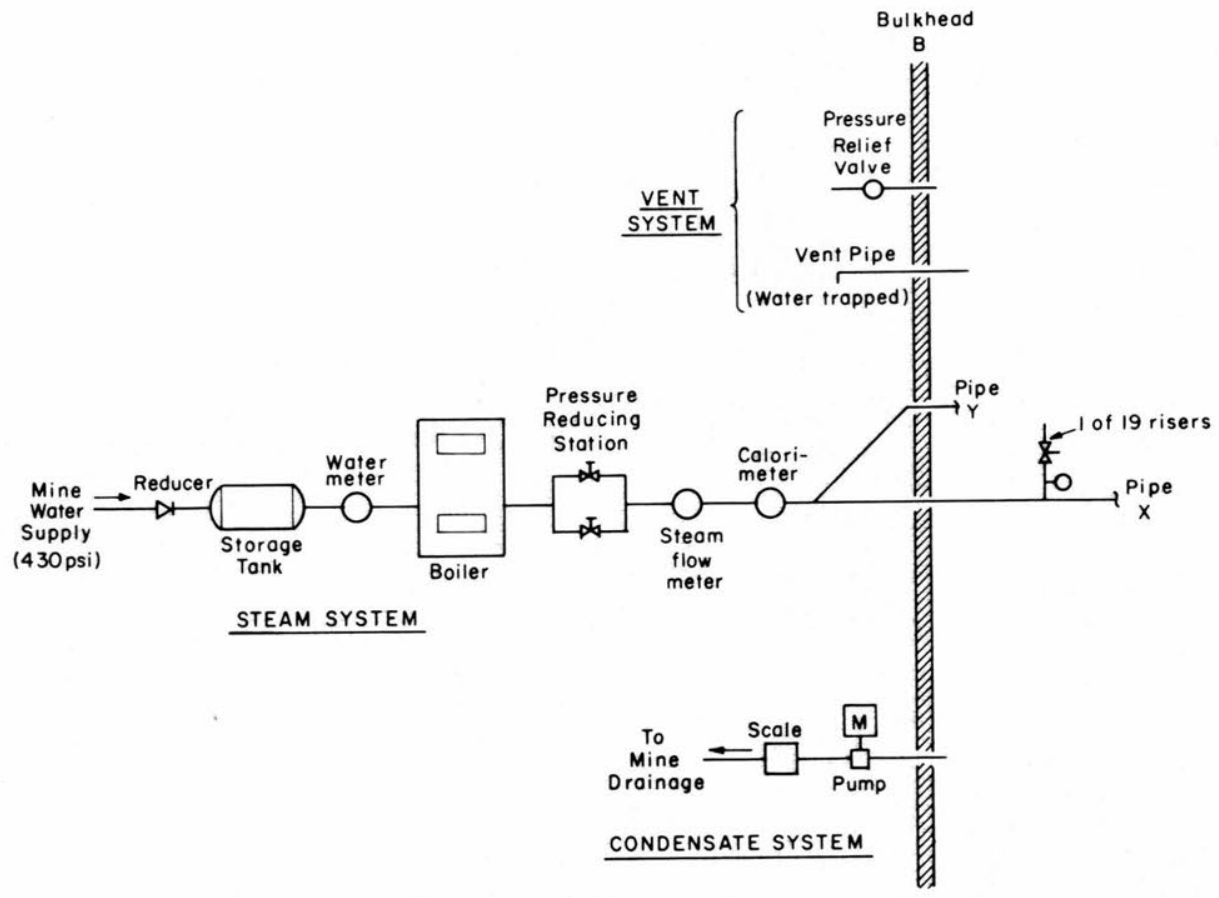

a. Steam, condensate and vent systems.

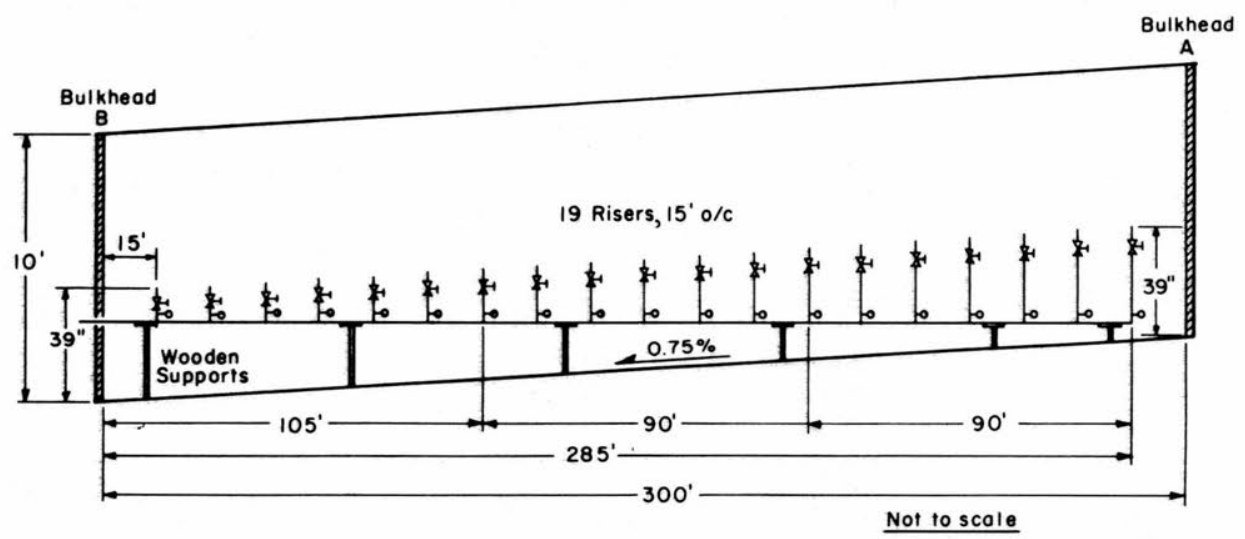

b. Internal pipe distribution system.

Figure 3. Steam production and distribution system.

Bulkhead B is shown in Figure 8. The recording system shown in the lower right of Figure $8 \mathrm{a}$ was used for audio-monitoring of rock movement that took place during cooling after the experiment was completed. An overall view of bulkhead B is shown in Figure 8b and a closeup view of the boiler in Figure 9 . 


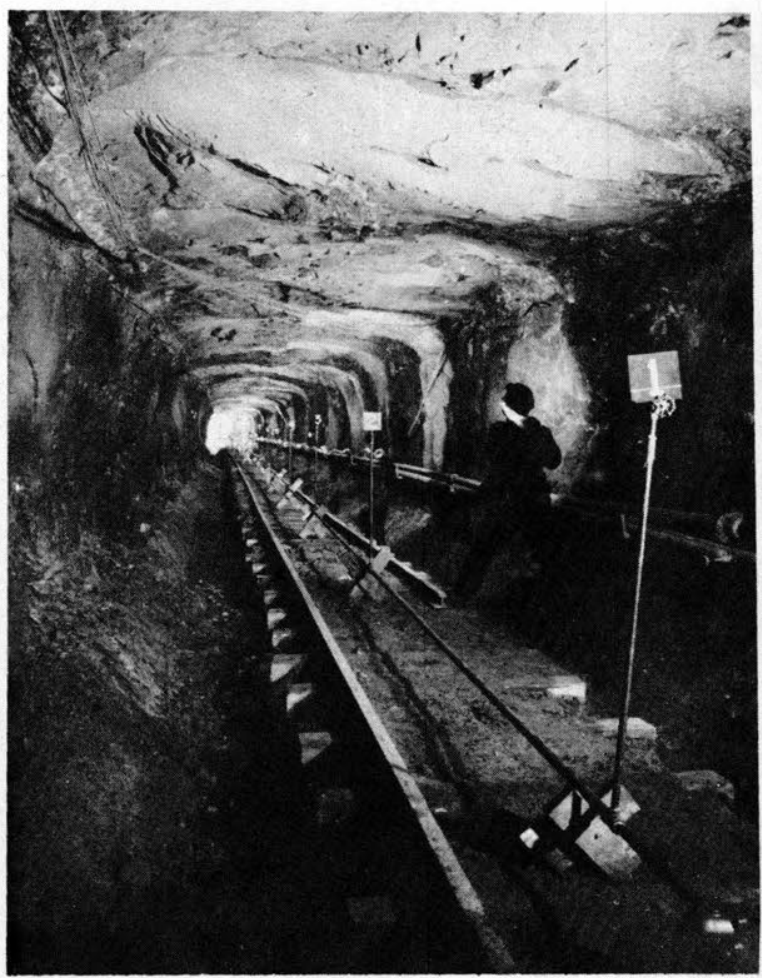

Figure 4. View of test tunnel from bulkhead $A$ (before test).

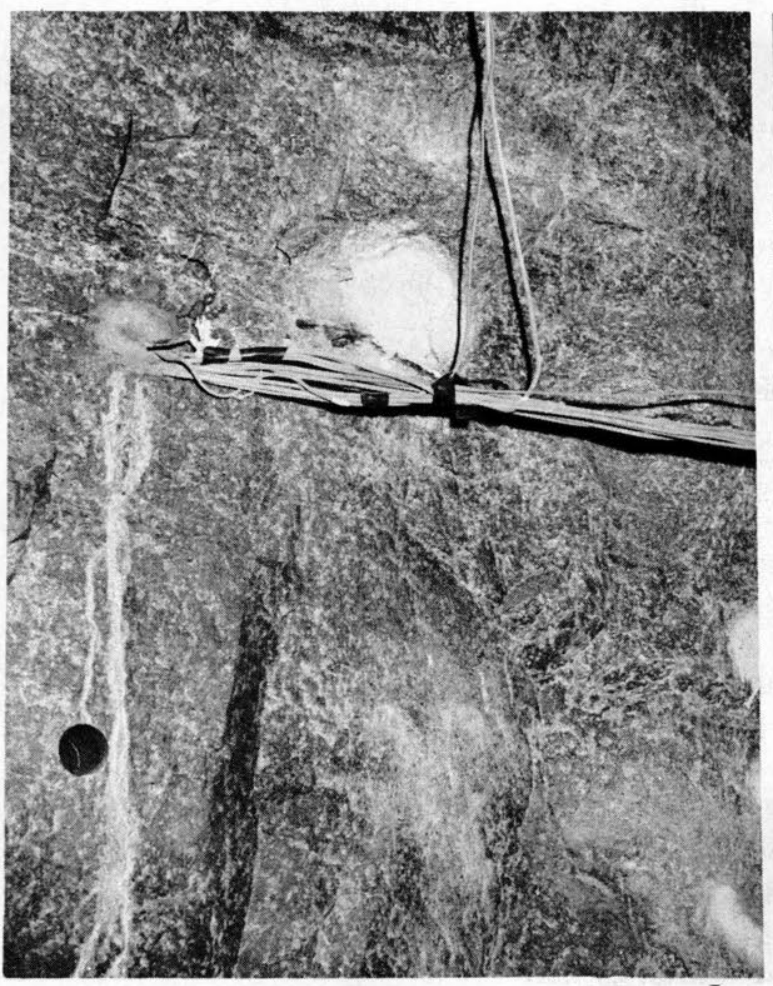

Figure 6. Thermocouple assembly (station 3, west wall).

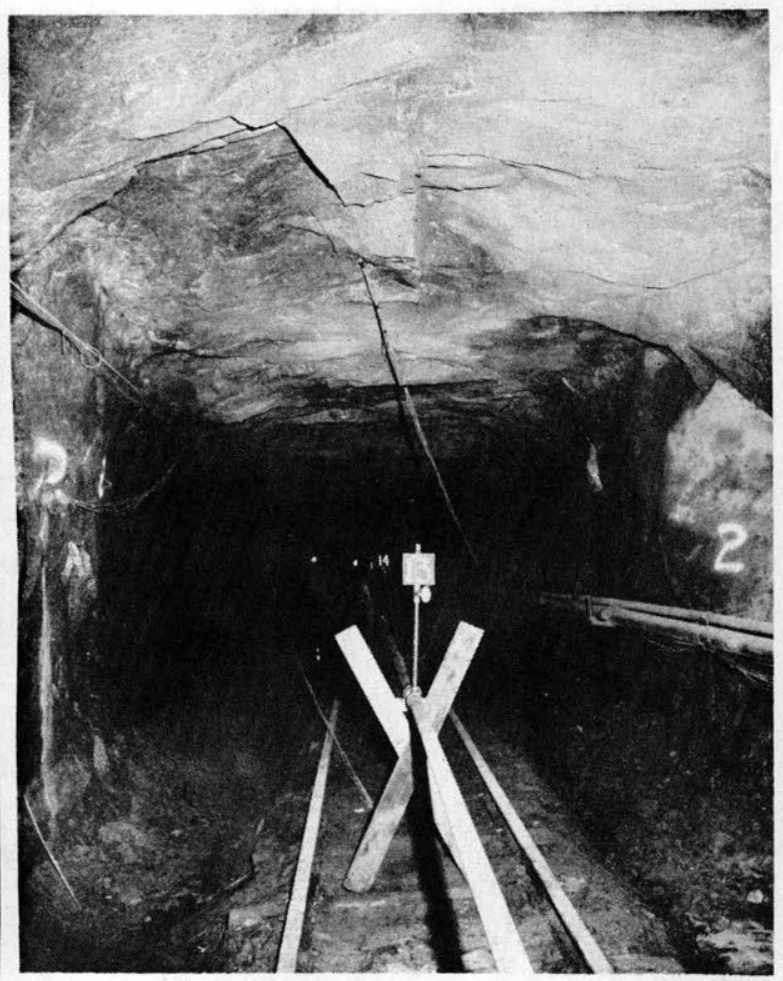

Figure 5. View of station 2 looking toward bulkhead $B$ (before test).

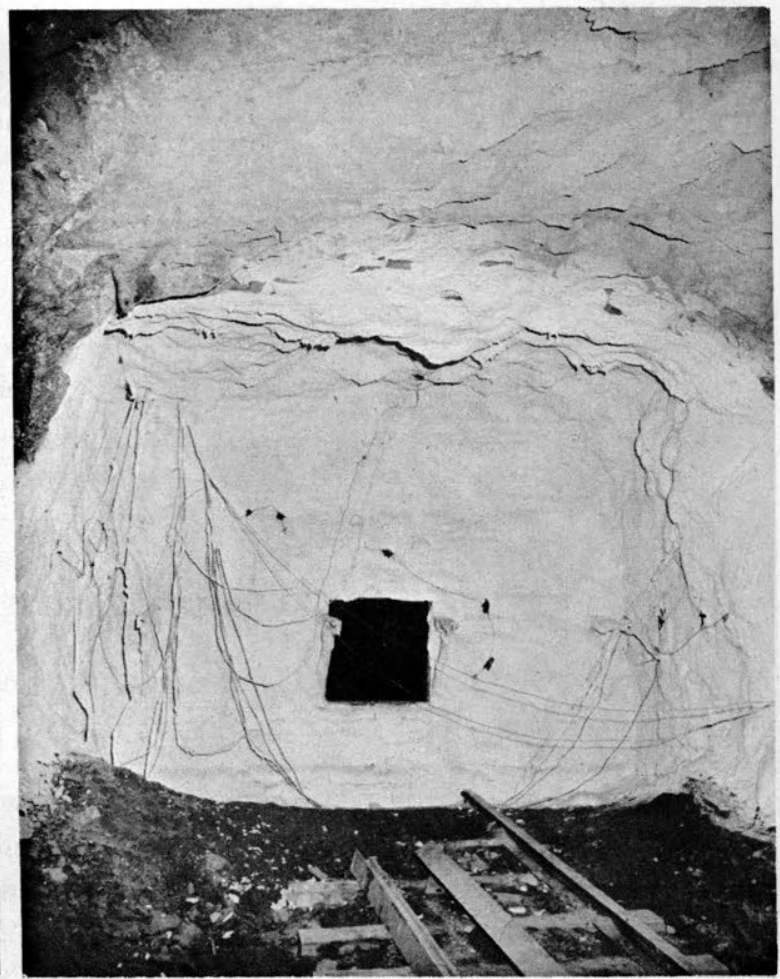

Figure 7. Bulkhead A. 


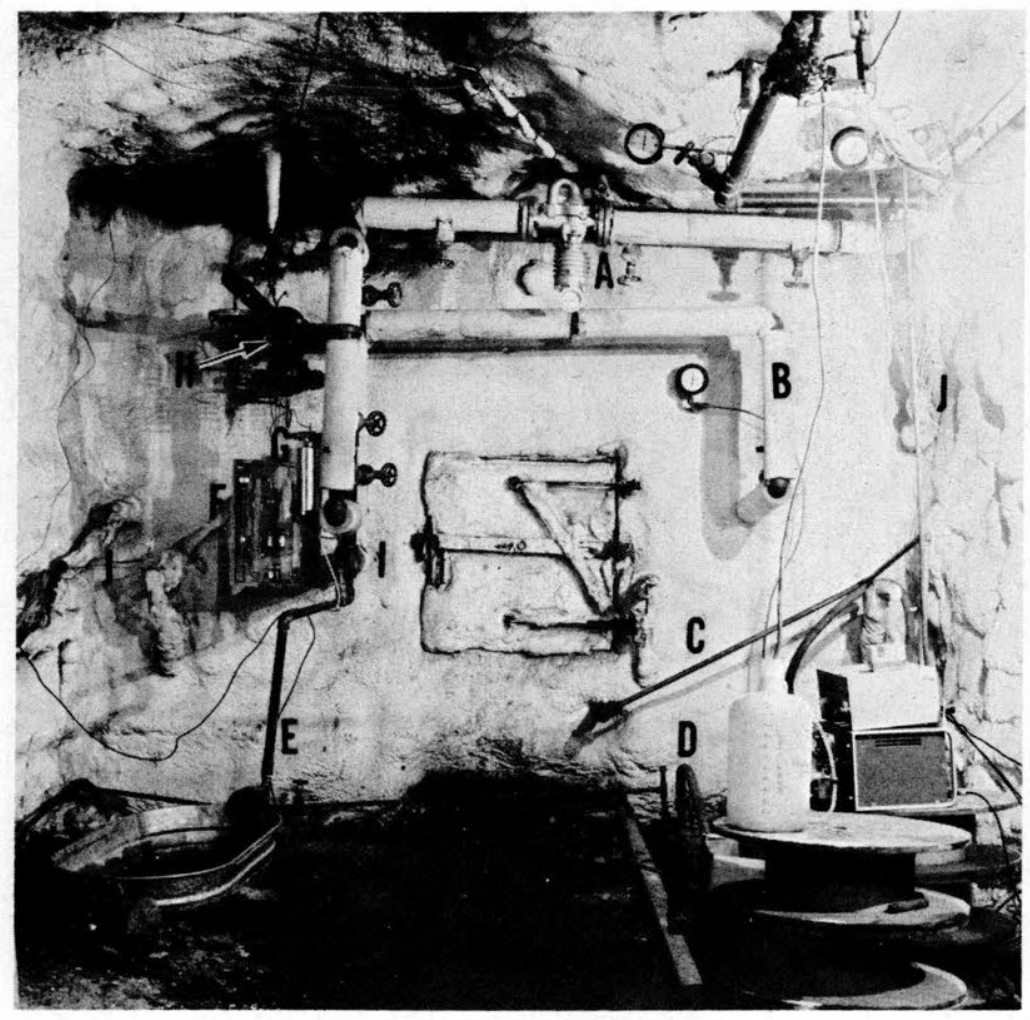

a. Closeup view.

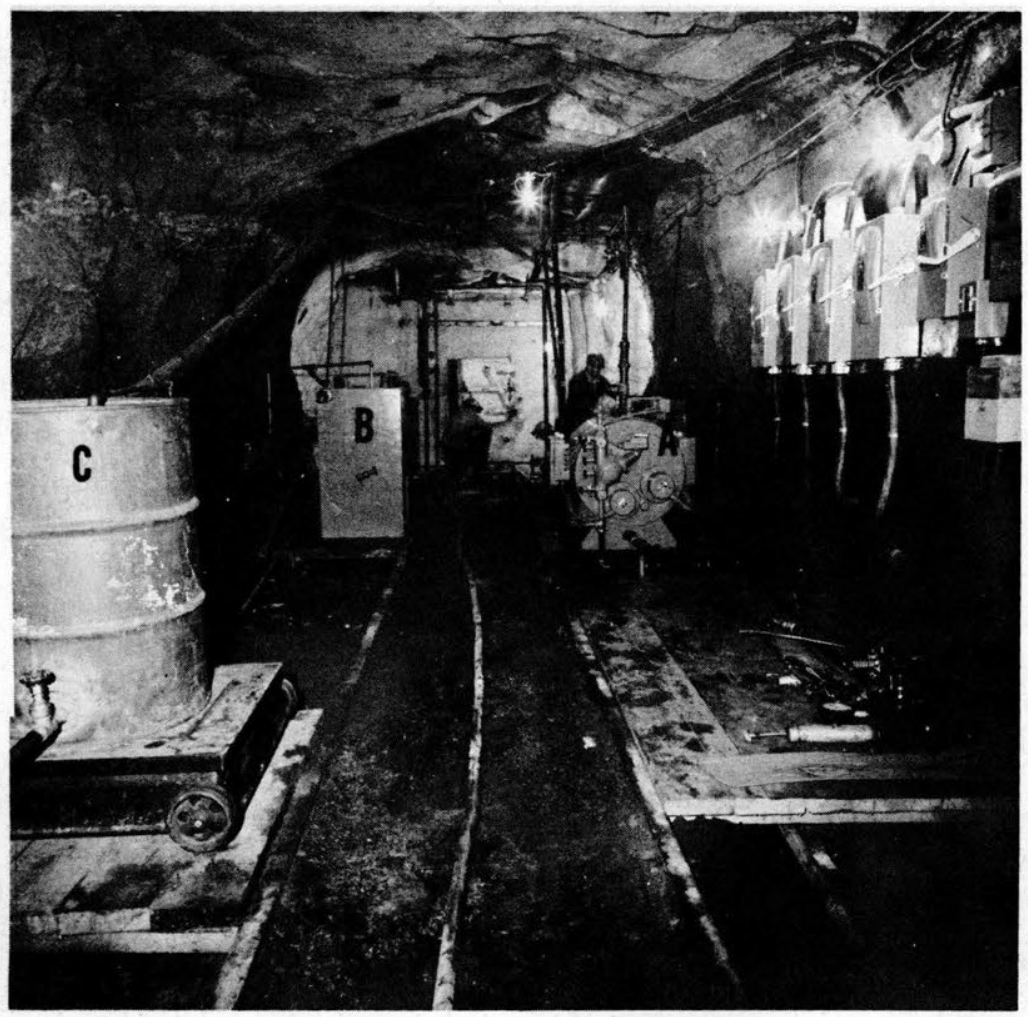

b. Overall view of steam delivery and condensate collection systems.
LEGEND:

A. STEAM FLOW METER

B. PIPE Y

C. VENT PIPE

D. CONDENSATE PUMP

E. STEAM TRAP

F. MANOMETER

G. CALORIMETER

H. RELIEF VALVE

I. PIPEX

J. THERMOCOUPLE WIRES
LEGEND:
A. BOILER
B. WATERSTORAGE TANK
C. CONDENSATE WEIGH STATION

Figure 8. Bulkhead B. 


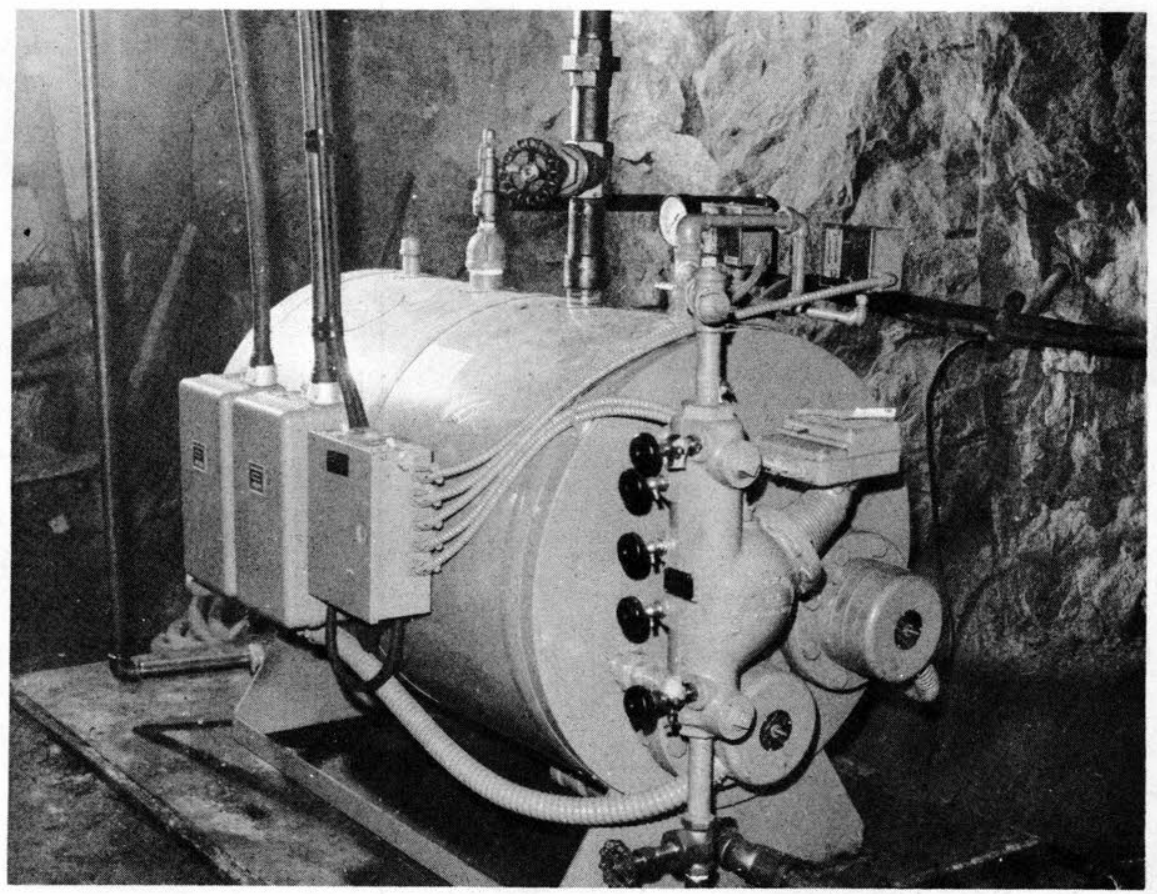

Figure 9. Electric boiler.

\section{PRELIMINARY HEAT TRANSFER ANALYSIS}

\section{Ther modynamic process}

The measured ambient rock and air temperatures in the test area were initially constant at $60^{\circ} \mathrm{F}$. The relative humidity as measured with a sling psychrometer was $100 \%$, which corresponds to a water vapor content of about $1 \%$ by weight. The partial pressure of the vapor (saturated vapor pressure) for this temperature condition is $0.25 \mathrm{psia}$. As previously noted, the average total atmospheric pressure was $15.25 \mathrm{psia}$. The partial pressure of the vapor is governed by its dewpoint, in this case the rock surface temperature (condenser temperature). When steam is introduced into the tunner, the rock surface temperature gradually rises, resulting in a corresponding increase in the dewpoint and associated vapor pressure.

The total pressure (air pressure plus vapor pressure) was maintained constant at atmospheric throughout the test by the continuous venting of air. Thus, the partial pressure of air (difference between total pressure and vapor pressure) continuously decreased. The vapor pressure can rise to a maximum of $15.25 \mathrm{psia}$, at which the dewpoint (rock surface temperature) is $213.8^{\circ} \mathrm{F}$. Variations in atmospheric pressure during the test resulted in a dewpoint ranging from $213.6^{\circ}$ to $214.9^{\circ} \mathrm{F}$.

The experiment is considered complete when the rock surface temperature reaches about $213.6^{\circ} \mathrm{F}$ at which time all of the air has been displaced and the tunnel is filled with pure steam. At this point the rock can no longer accept heat at the same constant rate. The steam flow rate must be reduced or the excess steam will either overflow through the vent or pressurize the tunnel.

Upon entering the test area the steam expands to ambient pressure and mixes with the air in the tunnel. Heat is transferred to the rock by both air convection and steam condensation on the rock surface. No information could be found in the literature regarding the heat transfer coefficient associated with the condensation of steam on rock. An objective of this test was to develop such 
information. A lower limiting transfer coefficient can be inferred from published data on heat transfer between air and rock surfaces which is on the order of $1.2 \mathrm{Btu} / \mathrm{ft}^{2} \mathrm{hr}{ }^{\circ} \mathrm{F}$ for free convection. ${ }^{\circ}$ An upper limiting transfer coefficient is obtained from experimentation with steam condensation in the absence of air on smooth metal surfaces which gives values on the order of $2000 \mathrm{Btu} / \mathrm{ft}^{2} \mathrm{hr}$ ${ }^{\circ} \mathrm{F} .{ }^{11}$. However, it is known that the presence of non-condensables has a significant effect on the coefficient of heat transfer.

It was estimated that the transfer coefficient between the tunnel atmosphere and the rock will increase during the course of the test as air is continuously vented from the test area. It was also estimated that initially, for an air-rich mixture, the transfer coefficient would probably be on the order of 1.2 .

\section{Prediction of air and rock surface temperatures}

Heat transfer to the rock may be approximated using an analytical model in which the test tunnel is represented by a hollow cylinder in an infinite medium, initially at a constant temperature, with heat flow at a constant rate by conduction in the radial direction. The problem has neen treated by Carslaw and Jaeger ${ }^{3}$ and the equation is given in the Appendix. The solution can be expressed as a dimensionless relationship between temperature rise at the surface $\Delta T$ and time $t$ :

$$
\frac{\Delta T k}{a \phi}=f\left(\frac{a t}{a^{2}}\right)
$$

An exact analytical solution of the basic equation is not possible. DA Technical Manual TM-855- $4^{6}$ provides a numerically computed graph of these dimensionless functions. A numerical solution of the equation was also developed by Stanley and Fellers, ${ }^{15}$ whose results are presented in the Appendix.

The underlying assumptions are: a homogeneous rock material with constant thermal conductivity $k$ and diffusivity $a$, a circular tunnel cross section of radius a, and a constant heat flux $\phi$. The actual situation involves a heterogeneous rock material with variable thermal properties, a rectangular tunnel cross section with rounded corners, and a slightly variable heat flux.

The theoretical relationship between heat flux and time to reach a rock surface temperature of $213.6^{\circ} \mathrm{F}$ for a temperature difference $\Delta T$ of $(213.6-60=) 153.6^{\circ} \mathrm{F}$ is given in Figure 10 for a tunnel diameter of $10 \mathrm{ft}$ and for both high and low values of the thermal conductivity for a rock of granitic composition. As indicated by the curves, the rock's thermal properties have a significant influence on warmup time. Figure 11 presents the influence of variation in the tunnel diameter on warmup time. For the same heat flux, the warmup time increases as the tunnel diameter decreases. Of course, a heat flux of $50 \mathrm{Btu} / \mathrm{ft}^{2} \mathrm{hr}$ in a 10 -ft-diam tunnel represents a smaller total heat load (on a lineal foot basis) than the same flux in a 15-ft tunnel. Lines of equal heat load per lineal foot are also shown in the figure. As would be expected, the smaller diameter tunnel attains saturation sooner.

For the Mineville experiment, a flux vs warmup time curve was prepared. As the tunnel was rectangular rather than circular, an equivalent radius was used on the basis of equal perimeters:

$$
a=2(10+13) / 2 \pi=7.33 \mathrm{ft} .
$$

The following rock properties, estimated from handbook values, ${ }^{4}$ were used (the experiment was designed prior to the measurement of thermal properties): 


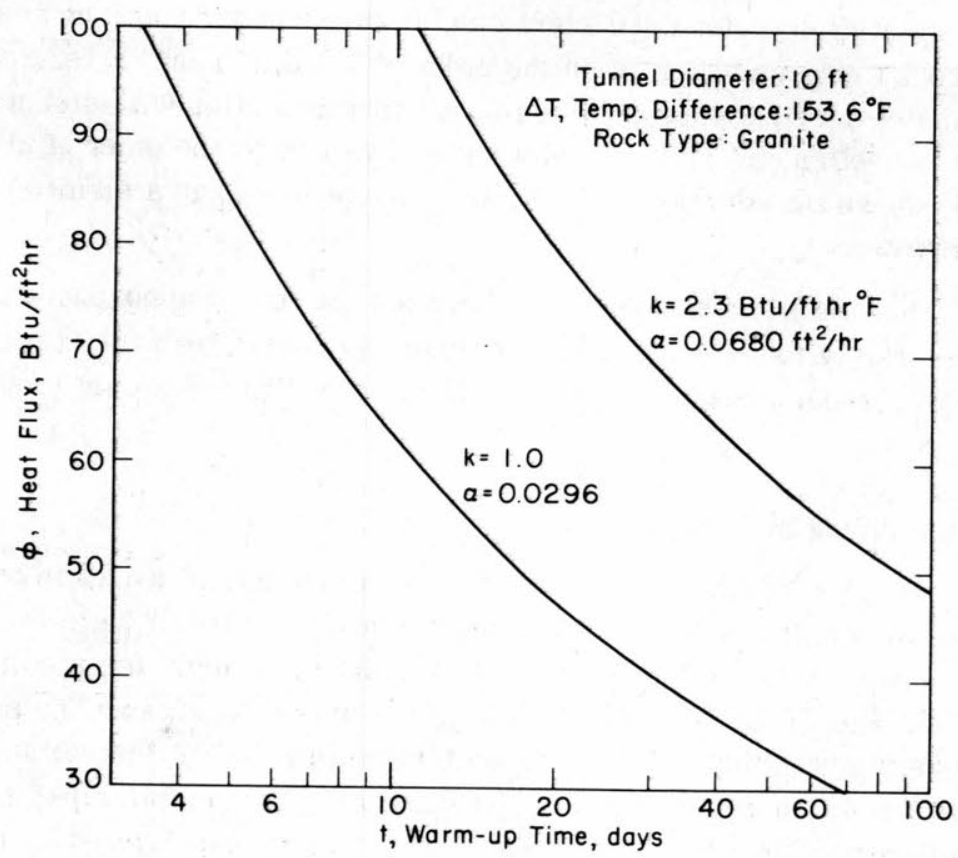

Figure 10. Theoretical effect of thermal properties on warmup time.

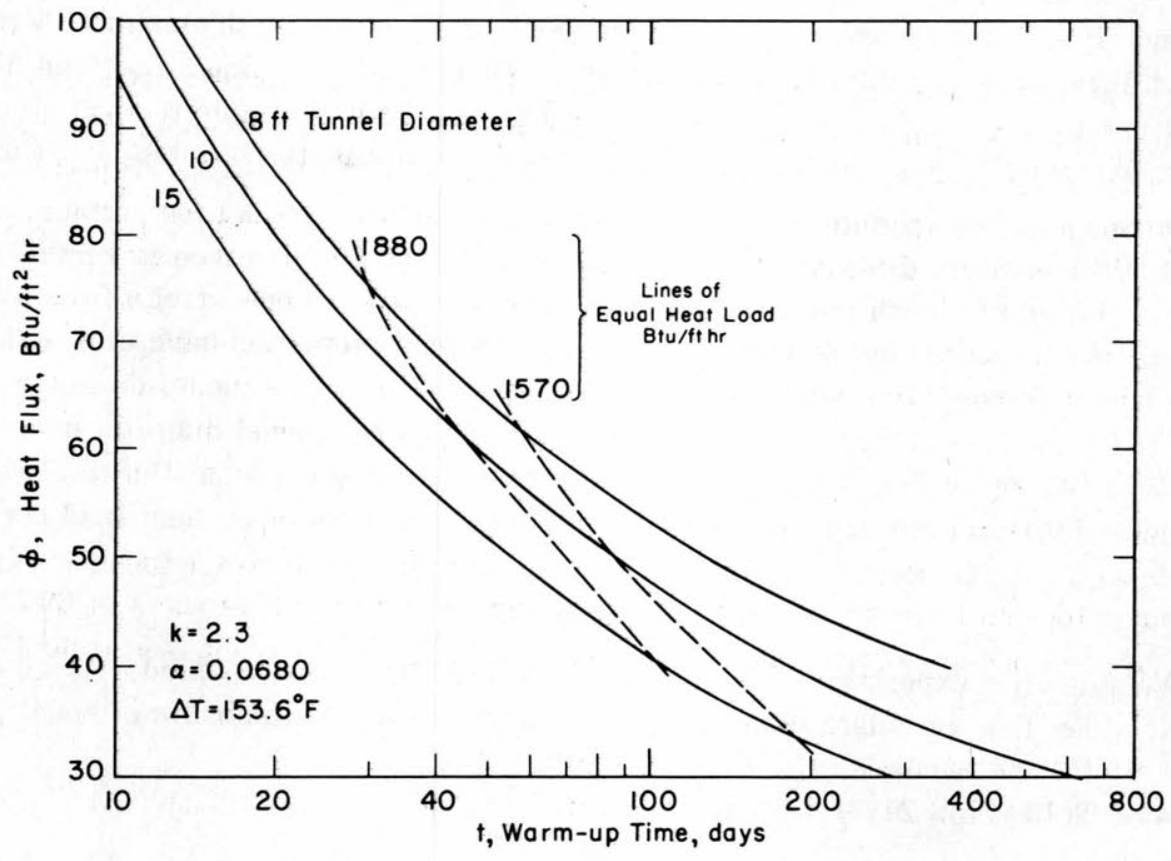

Figure 11. Theoretical effect of tunnel diameter on warmup time. 


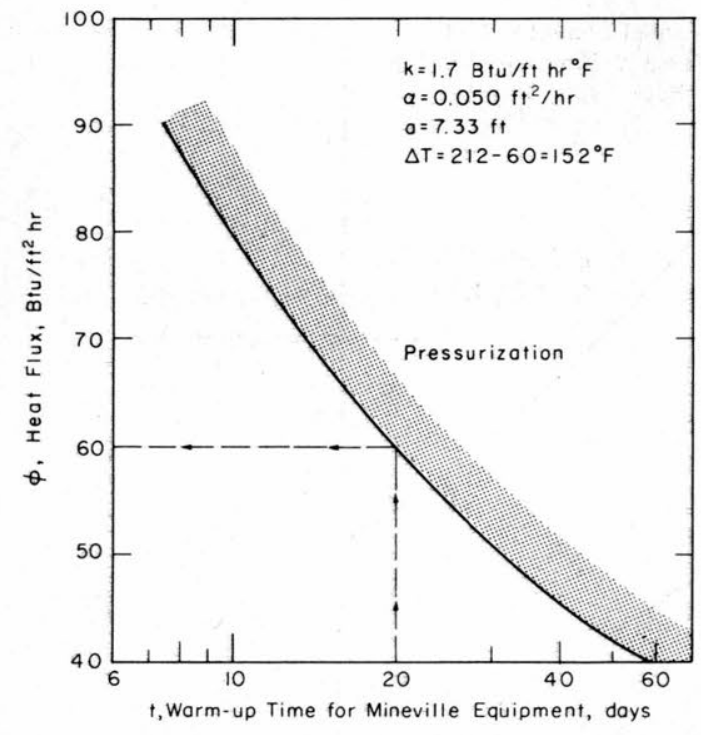

Figure 12. Theoretical relationship between heat flux and warmup time.

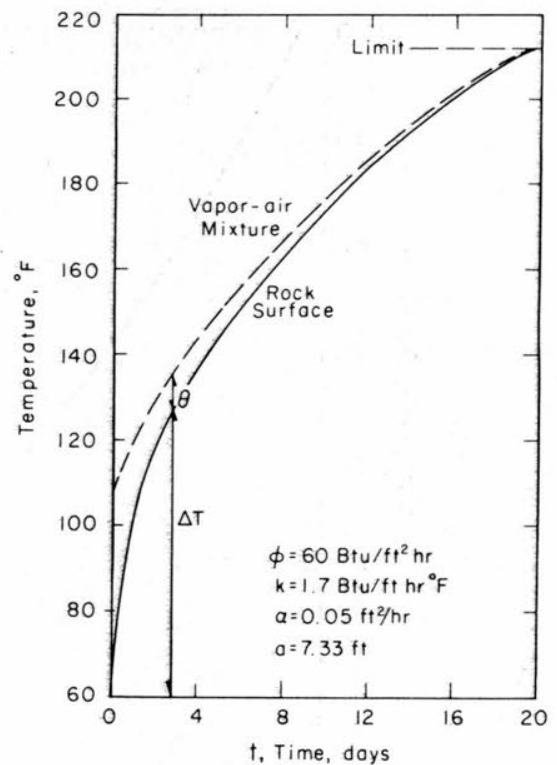

Figure 13. Theoretical vapor-air and rock surface temperatures vs time.

$$
\begin{aligned}
& k \quad 1.7 \mathrm{Btu} / \mathrm{ft} \mathrm{hr} F \\
& \rho=177 \mathrm{lb} / \mathrm{ft}^{3} \\
& c_{p}=0.19 \mathrm{Btu} / \mathrm{lb} / \mathrm{F} .
\end{aligned}
$$

The flux-warmup time relationship is given in Figure 12 and calculation details are given in Table AII in the Appendix. A temperature of $212 \mathrm{~F}$ was originally taken to represent the maximum dewpoint. A period of 20 days was considered to be a reasonable length of time to permit a comprehensive evaluation of both the thermal and physical processes. Entering the graph at 20 days a heat flux of $60 \mathrm{Btu} / \mathrm{ft}^{2}$ is found to be required. The tumnel surface area is on the order of l2(13, 10) $\times 300 \mathrm{l} \quad 13.800 \mathrm{ft}^{2}$ which represents a demand load of $60,13,800 \quad 828 \times 10^{4} \mathrm{Btu} / \mathrm{hr}$. Assuming that the heat from the saturated steam is solely its heat of condensation at $212 \mathrm{~F}(970$ $\mathrm{Btu} / \mathrm{lb})$, the steam production required is:

$$
\frac{828 \times 10^{3} \mathrm{Btu} / \mathrm{hr}}{0.97 \times 10^{3} \mathrm{Btu} / \mathrm{lb}} \quad 854 \mathrm{lb} / \mathrm{hr}
$$

A $5 \%$ allowance for end losses and steam quality results in a total requirement of $896 \mathrm{lb} / \mathrm{hr}$. Heat dissipation by the condensate was not considered. Assuming boiler feedwater at $60 \mathrm{~F}$, the boiler was sized as follows:

$\begin{array}{lc}\text { Heat of vaporization at } 212^{\circ} \mathrm{F} & 970 \mathrm{Btu} / \mathrm{lb} \\ \text { Water enthalpy at } 212^{\circ} \mathrm{F} & 180 \\ & 1150 \\ \text { Water enthalpy at } 60^{\circ} \mathrm{F} & 28 \\ \text { Energy required } & 1122 \mathrm{Btu} / \mathrm{lb} \\ \text { Boiler size } & (1122)(896) / 3412-295 \mathrm{kw}\end{array}$

The predicted change in surface temperature with time is given in Figure 13 and the details of the calculation are presented in Table AIII of the Appendix. 


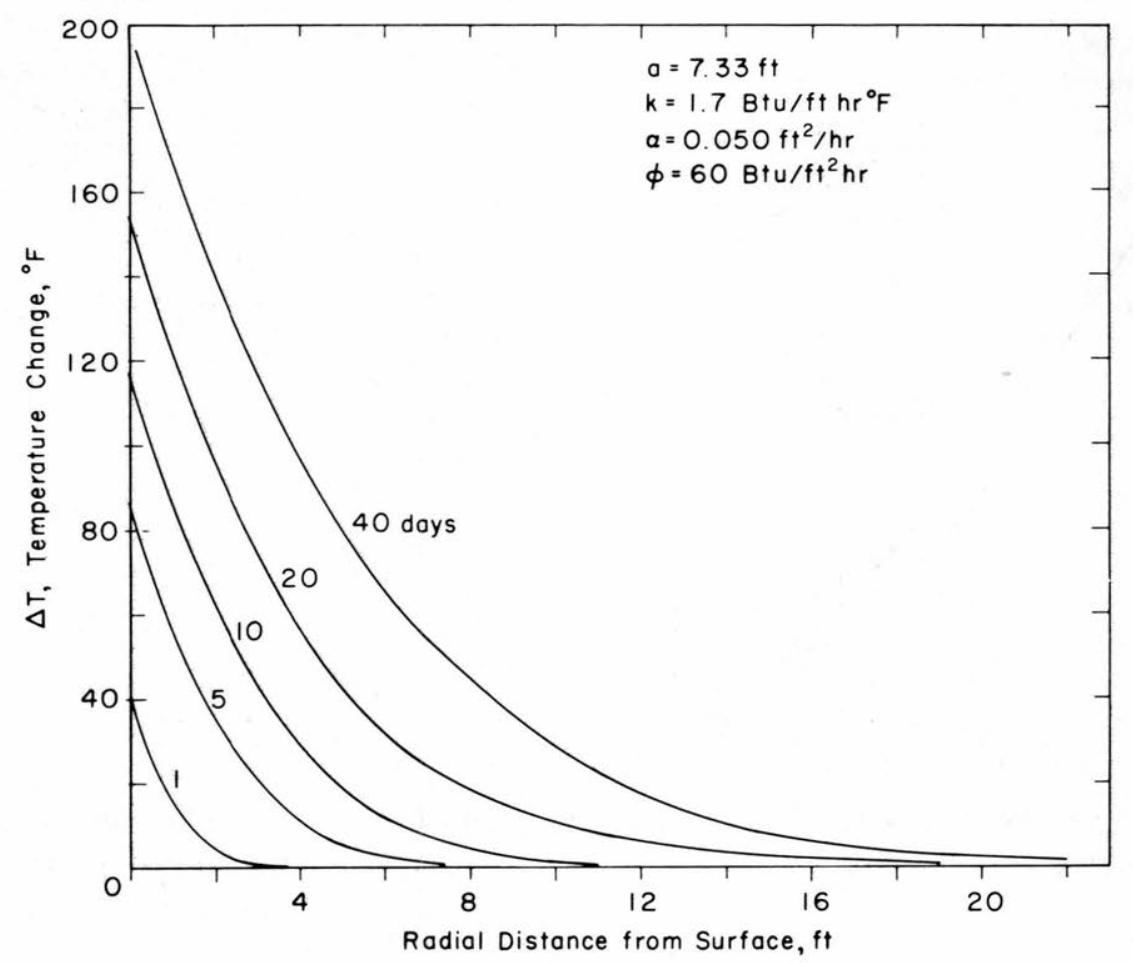

Figure 14. Theoretical radial temperatures at selected times.

The curve depicting the vapor-air mixture temperature with time is only an approximation. At the start of the test, the theoretical temperature differential between the air-rich tunnel atmosphere and rock is on the order of $48^{\circ} \mathrm{F}$, assuming a transfer coefficient of 1.2 . The tunnel temperature was expected to rise rapidly at first to about $108^{\circ} \mathrm{F}(60+48)$. The heat capacity of the tunnel air was about $740 \mathrm{Btu} /{ }^{\circ} \mathrm{F}$, and with $828 \times 10^{3} \mathrm{Btu} / \mathrm{hr}$ this temperature differential would occur in less than 3 minutes. Toward the end of the test the surface transfer coefficient might be on the order of 100 which would result in a differential $\theta$ of $0.6^{\circ} \mathrm{F}$. Between the beginning and end of the test, the temperature difference between the rock surface and tunnel atmosphere was expected to decrease exponentially.

\section{Prediction of radial temperature gradients}

The radius of temperature influence for times of $1,5,10,20$ and 40 days is given in Figure 14 for a flux of $60 \mathrm{Btu} / \mathrm{ft}^{2} \mathrm{hr}$, a conductivity of $1.7 \mathrm{Btu} / \mathrm{ft} \mathrm{hr}{ }^{\circ} \mathrm{F}$ and a radius of $7.33 \mathrm{ft}$. These curves were developed from the tabulated numerical solutions presented in the Appendix. A temperature change of about $1^{\circ} \mathrm{F}$ is predicted at a radial distance of $20 \mathrm{ft}$ in a 20 -day test. Note that the gradients of the curves at the wall surface are parallel, indicating the constant heat flux across the surface.

\section{TUNNEL CONDITION AFTER THE TEST}

Before discussing the experimental results, it is useful to have an appreciation of the rock distress caused by the introduction of live steam.

Upon termination of the test and after overnight cooling, the access door in bulkhead B was opened to reveal a pile of rock rubble about $5 \mathrm{ft}$ deep (Fig. 15). The fog in the tunnel at that time 


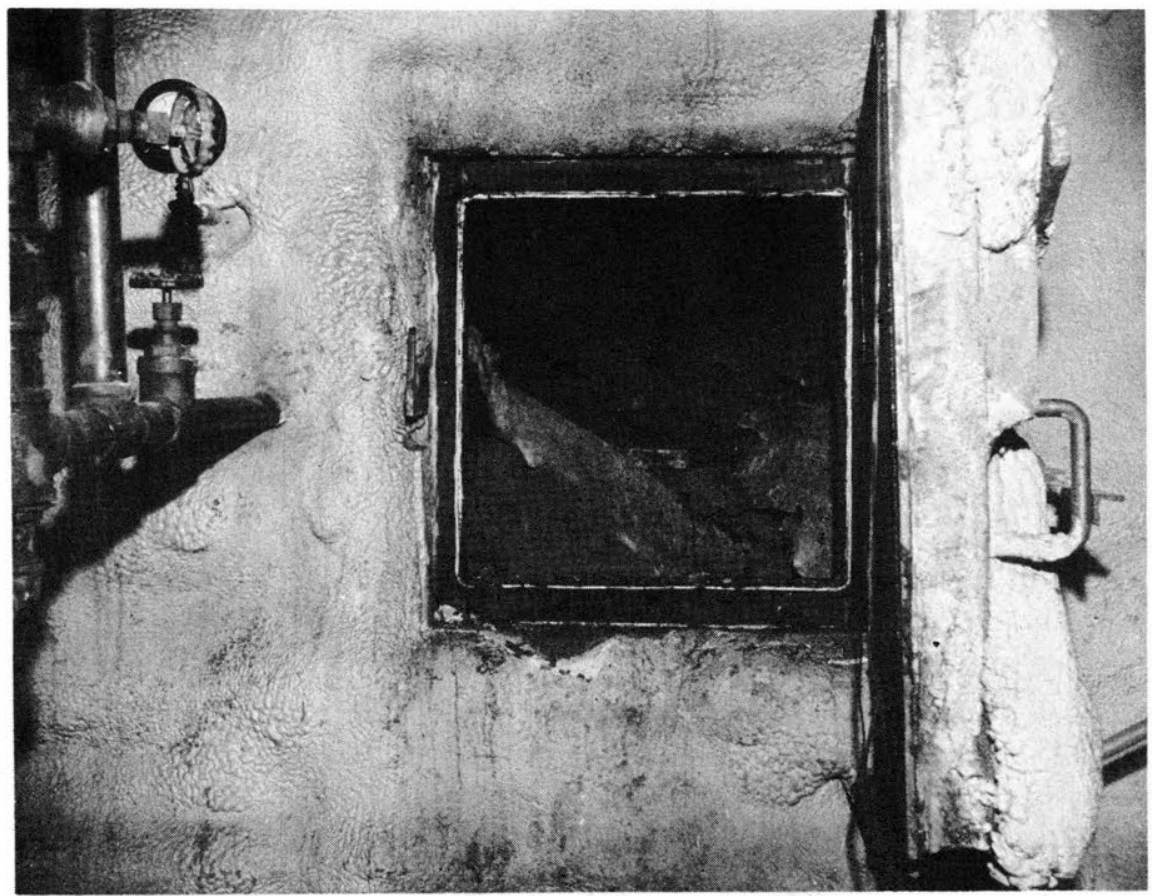

Figure 15. View of rock rubble through access door in bulkhead $B$.

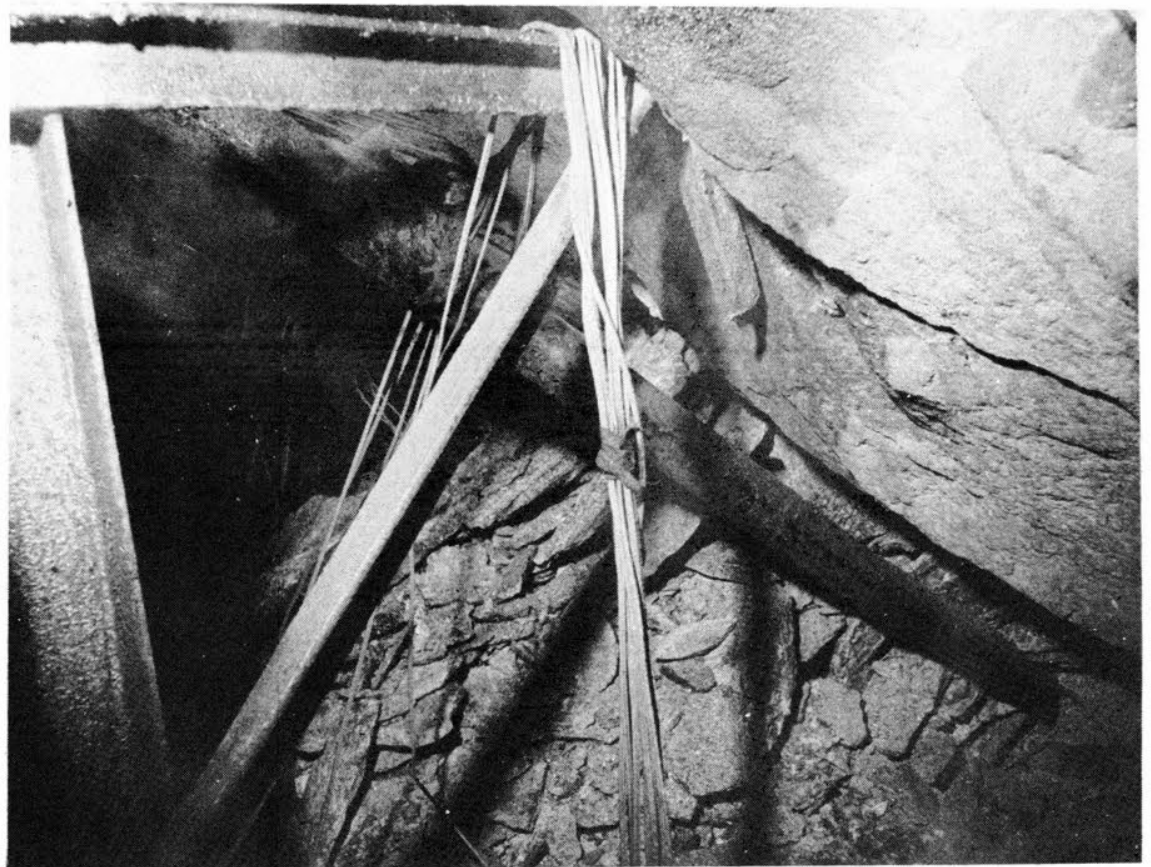

Figure 16. Rock debris adjacent to bulkhead $B$. 
obscured vision beyond about $50 \mathrm{ft}$. A view of the east side of the test area just within the access door is given in Figure 16. This photograph shows the damage to pipe $\mathrm{X}$ and to some of the thermocouple wires. The slabby nature of the rock debris is evident.

Prior to the cleanup operation a muck pile averaging $5 \mathrm{ft}$ in depth covered the floor from bulkhead $B$ for a distance of $70 \mathrm{ft}$ into the test area. From 70 to $115 \mathrm{ft}$ (vicinity of sta. 2) a heavy rock fall occurred which enlarged the drift from 13 to $17 \mathrm{ft}$ in width and from 10 to $35 \mathrm{ft}$ in height. The rubble pile in this region was about $30 \mathrm{ft}$ high. From 115 to $165 \mathrm{ft}$, the drift roof sloped downward to a height of $12 \mathrm{ft}$ at which location another, smaller dome developed about $14 \mathrm{ft}$ wide by $16 \mathrm{ft}$ high from 165 to $183 \mathrm{ft}$. The remainder of the tunnel was covered with a pile of rubble about $2.5 \mathrm{ft}$ deep. The mucking operation required the removal of 323 carloads or roughly 2585 tons of rock. Using an in-place density of $178 \mathrm{lb} / \mathrm{ft}^{3}$, this represents an average of about $3 \mathrm{ft}$ of rock-fall from the two walls and roof of the test area.

Figure 17 shows roof lagging installed after the test; but the most significant feature is the extremely smooth walls which developed as a result of the spalling. (Figure 5 shows the conditions in this region before the test.) Figure 18 shows the condition of the tunnel in the vicinity of station 1. Severed thermocouple wires can be seen hanging from the ceiling. Again note the smooth texture of the roof and walls and the tendency for the corners to round out. A view of the yet-to-becleared rubble pile in the vicinity of bulkhead A is shown in Figure 19; damaged header pipe $X$ is also evident. In some cases the rock bolts held sections of roof intact, in others the bolts remained in place and the rock spalled away (Fig. 20). As noted above, considerable distress developed in the vicinity of station 2 (Fig. 21). This catastrophic collapse is attributed to an open seam less than $1 / 32$ inch wide which diagonally intersected the tunnel as shown on Figure 1 . The seam can be observed in the roof above the lagging in Figure 21. Although several other seams were present in the test area, they were oriented normal to the tunnel axis and did not develop the distress pattern found at station 2. Figure 22 is a photo taken just prior to mucking in the vicinity of the large fall.

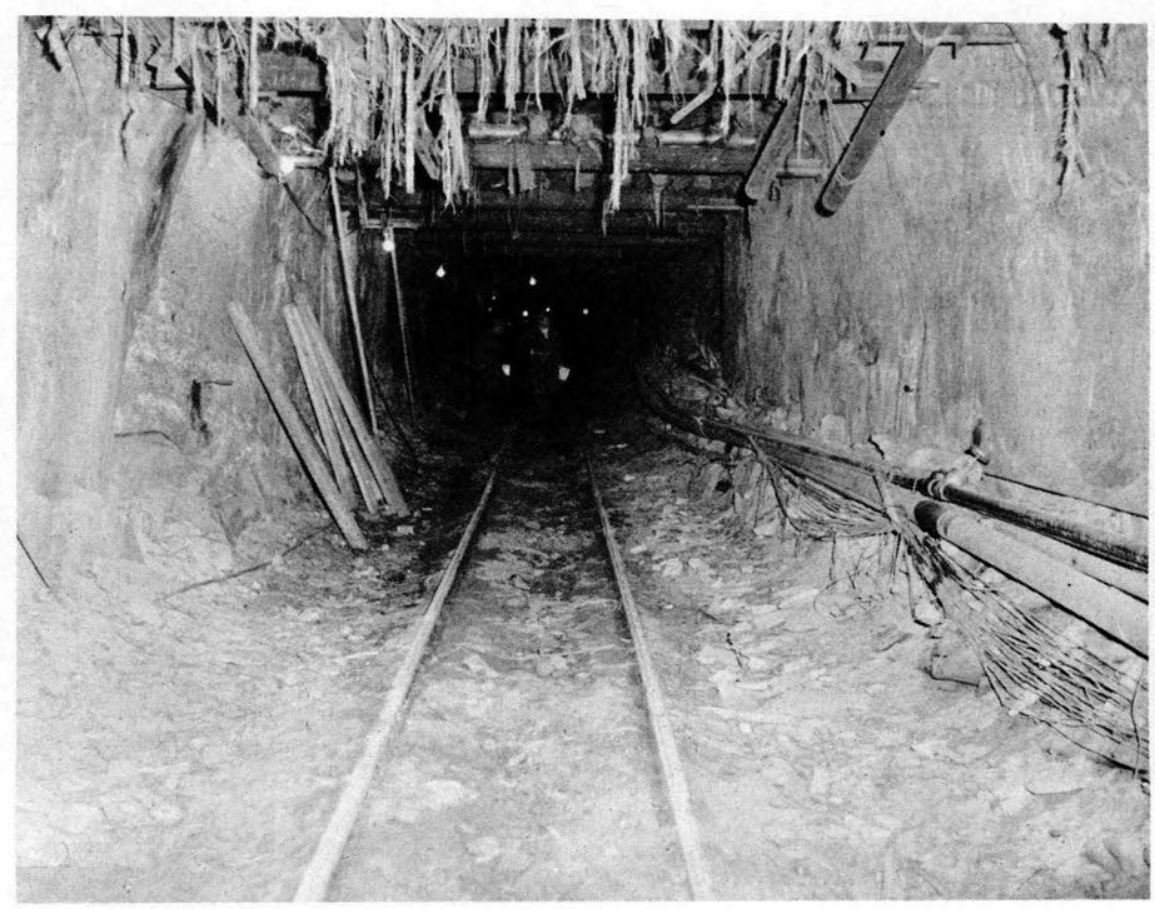

Figure 17. View of tunnel after it was cleared of rubble. (Camera at station 2, personnel at station 3.) 


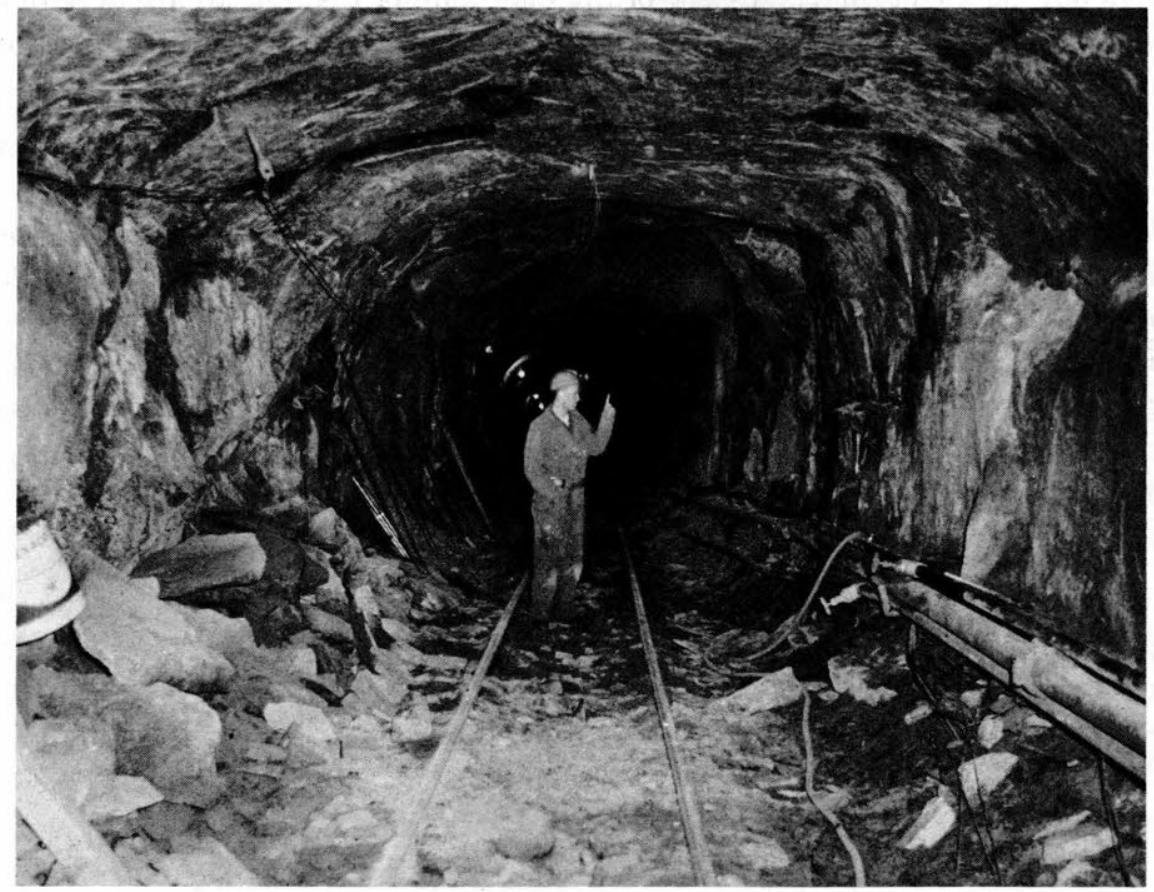

Figure 18. View in vicinity of station 1 following test.

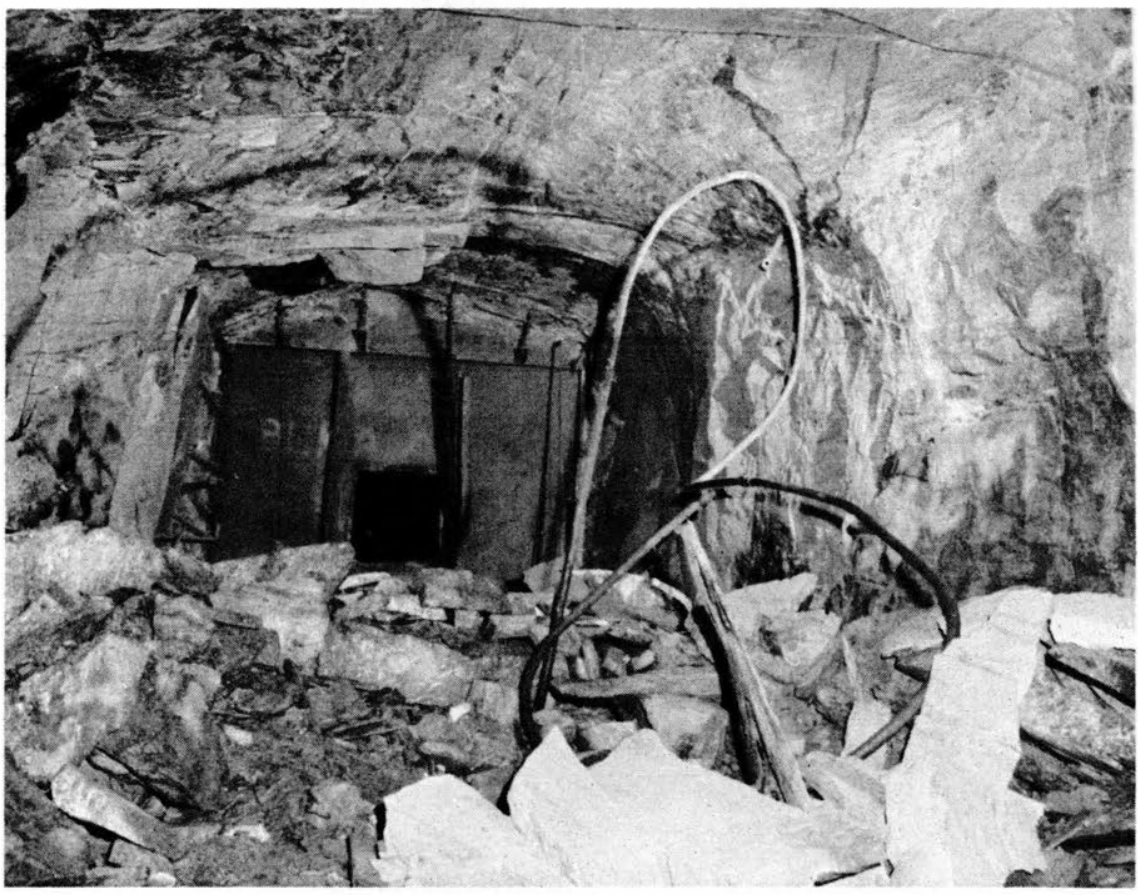

Figure 19. Rubble pile near bulkhead $A$. 


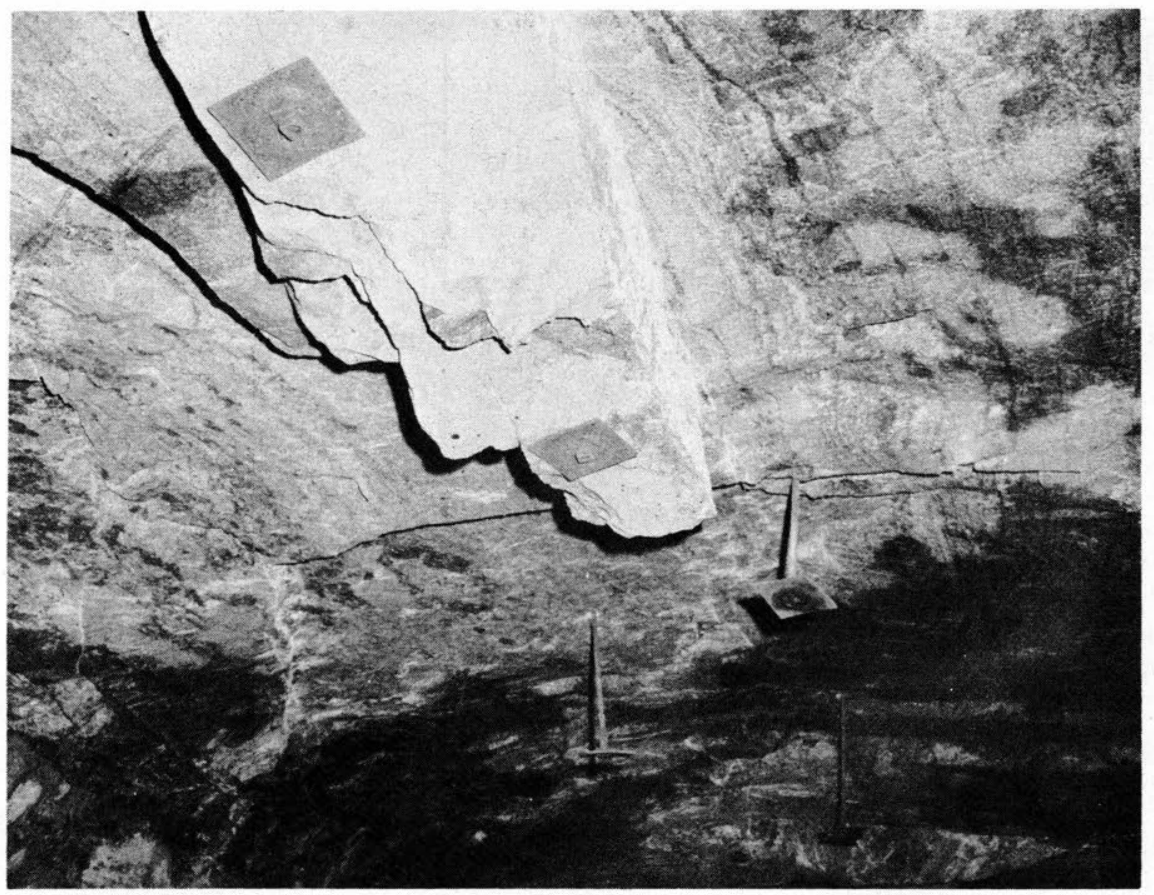

Figure 20. View of rock bolts after test.

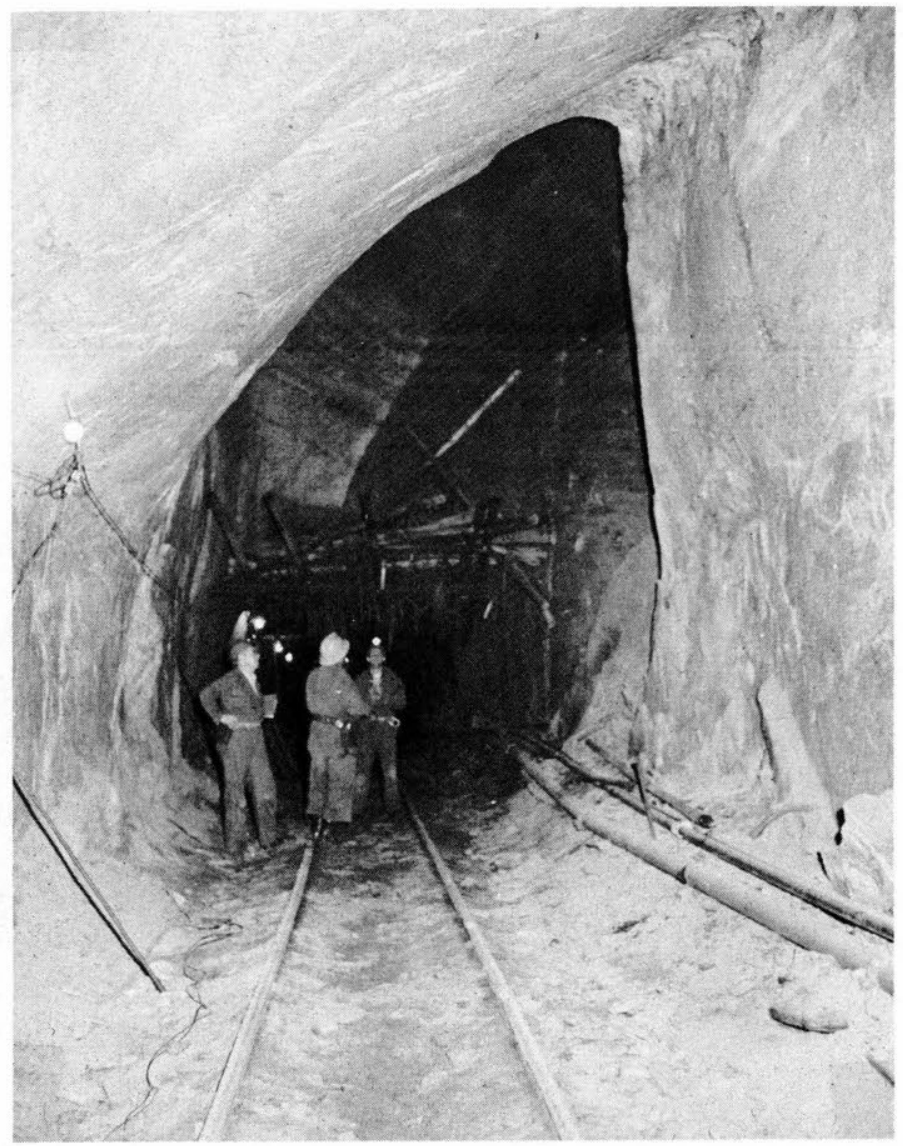

Figure 21. Cathedral-like roof developed at station 2 , 


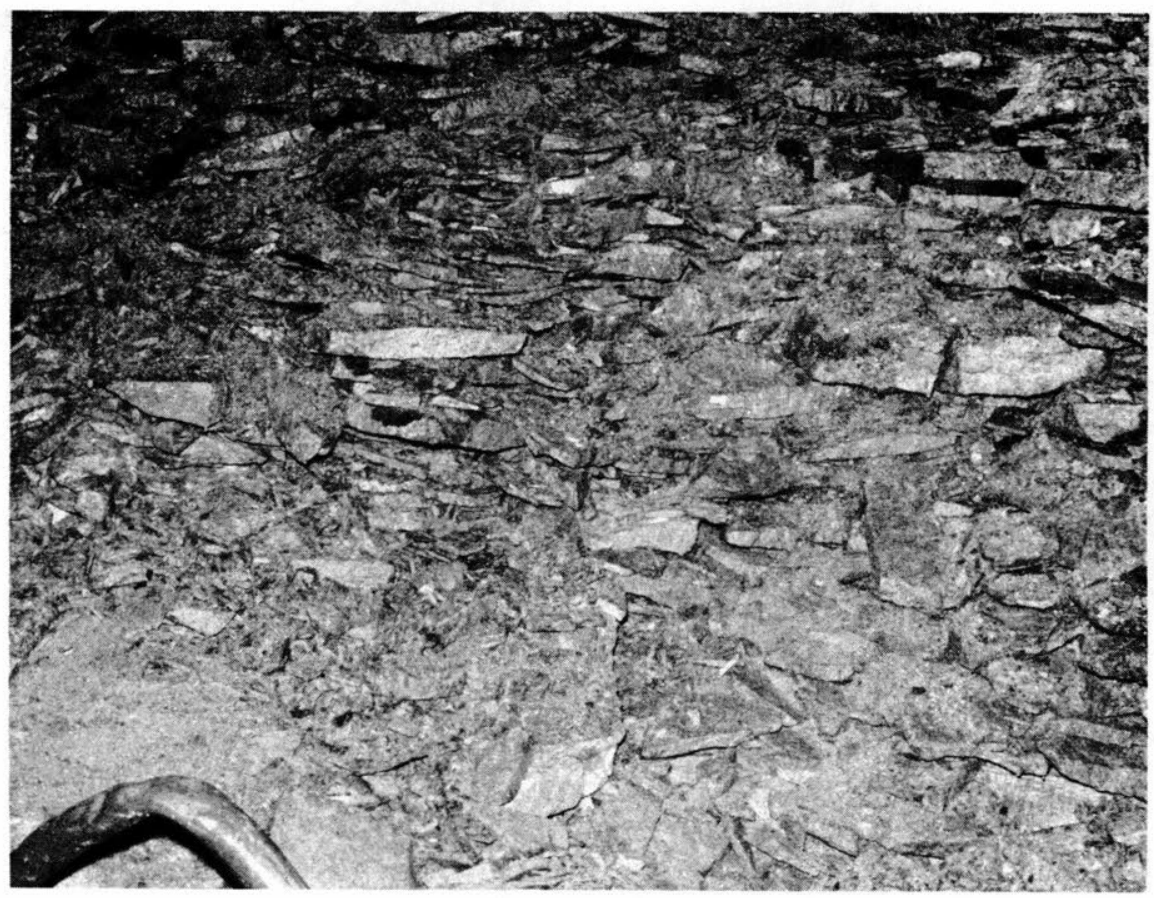

Figure 22. Rock debris near station 2.

The camera was held in a horizontal plane with the rubble pile essentially vertical. For size perspective, the twisted 2-in. header $\mathrm{X}$ is shown in the lower left corner. The pile resembled a very tight, dry stone wall. It is interesting to note the similarities between this rubble pile and those associated with failure attributed to erosion of gouge-filled seams in unlined hydraulic tunnels. ${ }^{5}$ Slabs developed during spall ranged from fines up to about $8 \mathrm{in}$. in thickness.

\section{TEST RESULTS}

The test was begun at 1030 hours on 18 June 1968 and was conducted for 37.2 days (892 hours), ending at 1415 hours on 25 July.

As previously mentioned, it was planned to use pipe $\mathrm{X}$ to distribute steam uniformly throughout the major portion of the experiment. This plan was aborted after $101 / 2$ hours of testing because a large slab fell and broke the pipe. Steam was then diverted to pipe $\mathrm{Y}$ for the remainder of the test, and the entire steam load was dumped between stations 3 and 4 . The air temperature measured $1 \mathrm{in}$. from the rock surface on the west side of the tunnel (Fig. 23a) indicates that the distribution of steam longitudinally throughout the test area was relatively uniform. The temperature on the surface of bulkhead $\mathrm{A}$ at the far end of the test area is also given for comparison. Air temperatures at stations 2 and 3 are in close agreement. The air temperature at station 1 is consistently about $3^{\circ}$ to $4^{\circ} \mathrm{F}$ less than at stations 2 and 3 , indicating a slight longitudinal variation ( $3^{\circ}$ to $4^{\circ} \mathrm{F} / 100 \mathrm{ft}$ ). A similar relationship is found in comparing air temperatures on the east side of the tunnel (Fig. 23b). The comparison also shows that the air temperatures on both sides of the tunnel were in good agreement at each station. It is noted that the air on the east side at station 3 apparently cooled on 27 June (10th day); cooling was not observed on the west side.

Figure 24a compares air temperatures at the roof and wall at station 1 and shows that roof temperatures are about $3^{\circ} \mathrm{F}$ higher. Figure $24 \mathrm{~b}$ gives the roof, wall, and floor surface temperatures at station 1 and indicates that a definite temperature stratification existed, with the floor being 


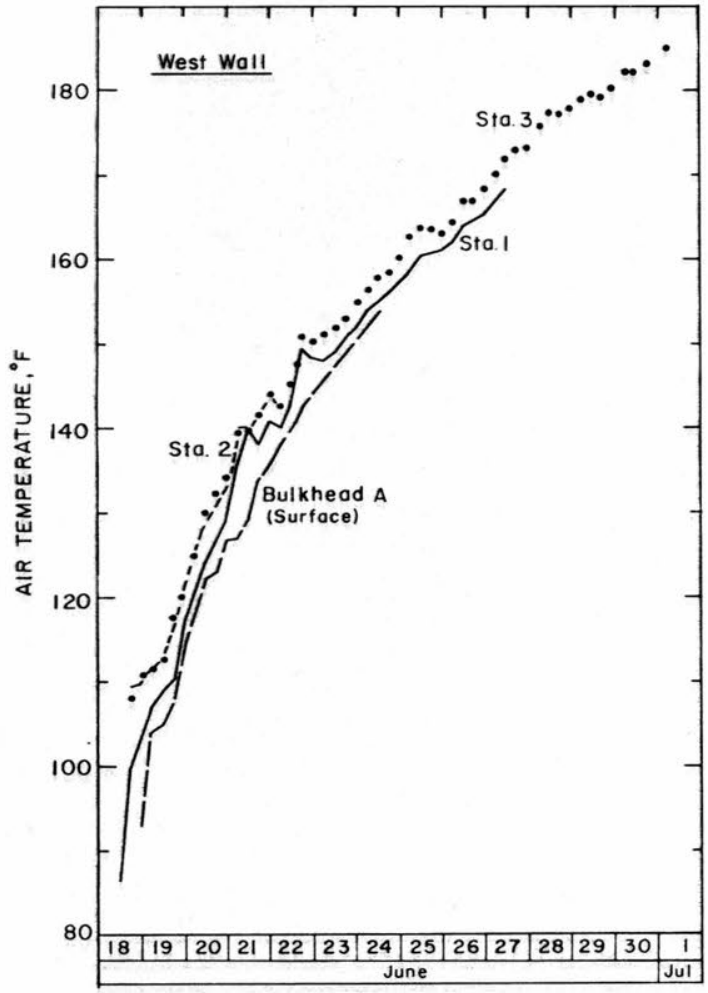

a. West wall.

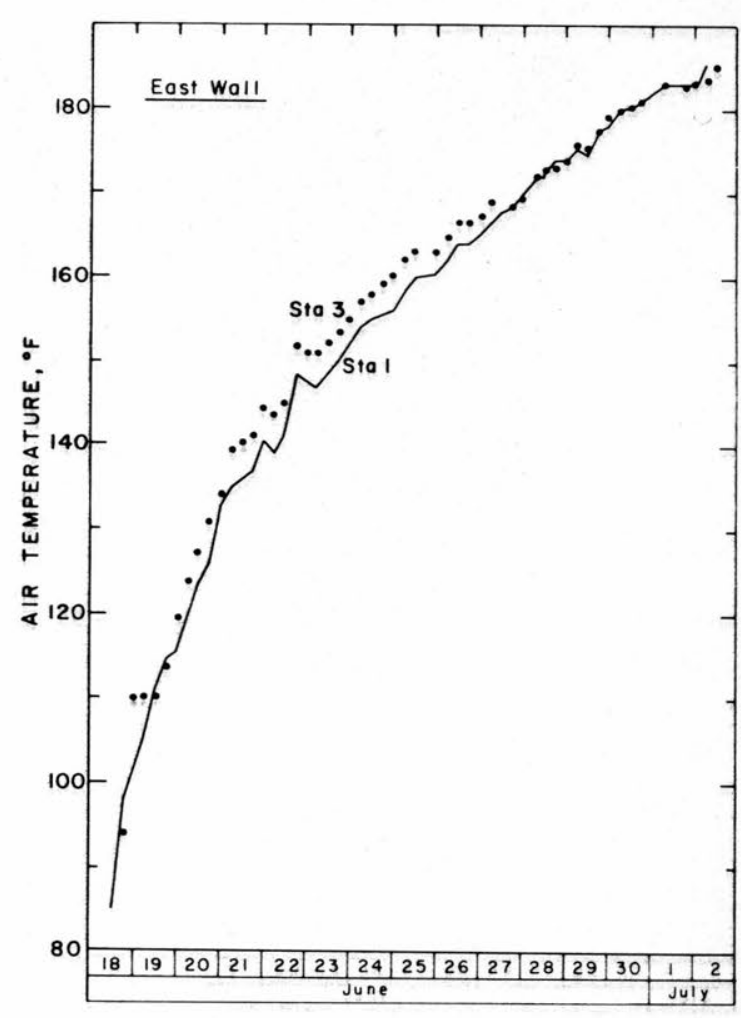

b. East wall.

Figure 23. Air temperatures vs time at various stations.

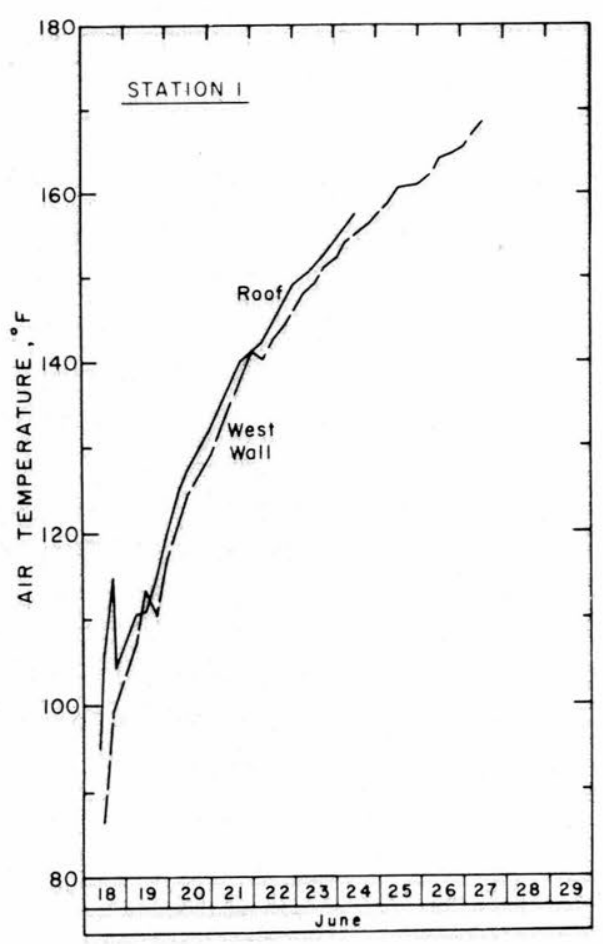

a. Air temperatures.

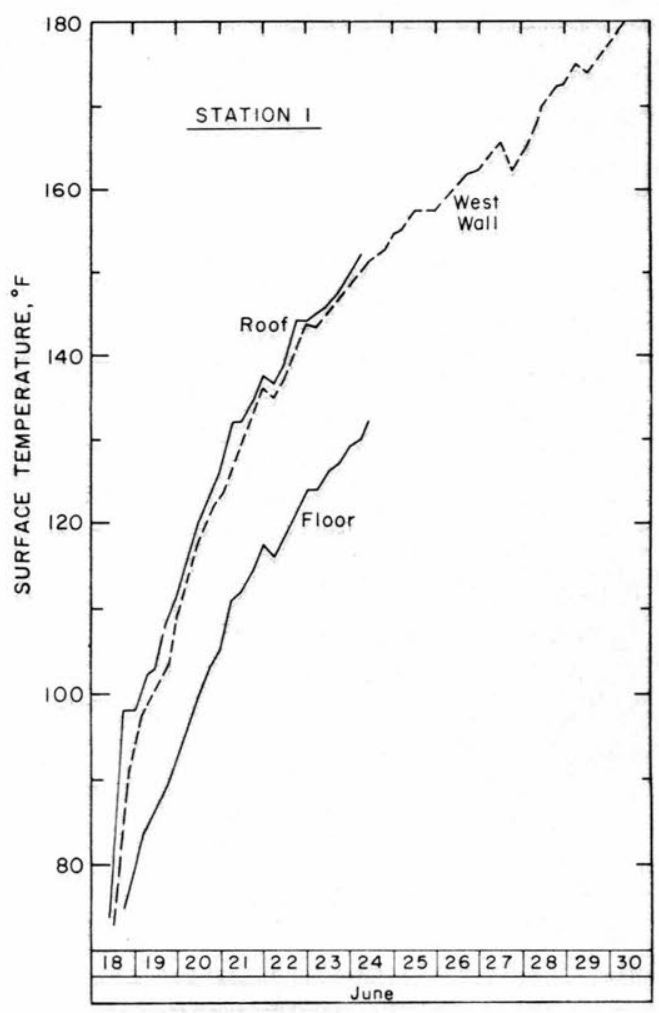

b. Surface temperatures.

Figure 24. Temperatures vs time at station 1. 


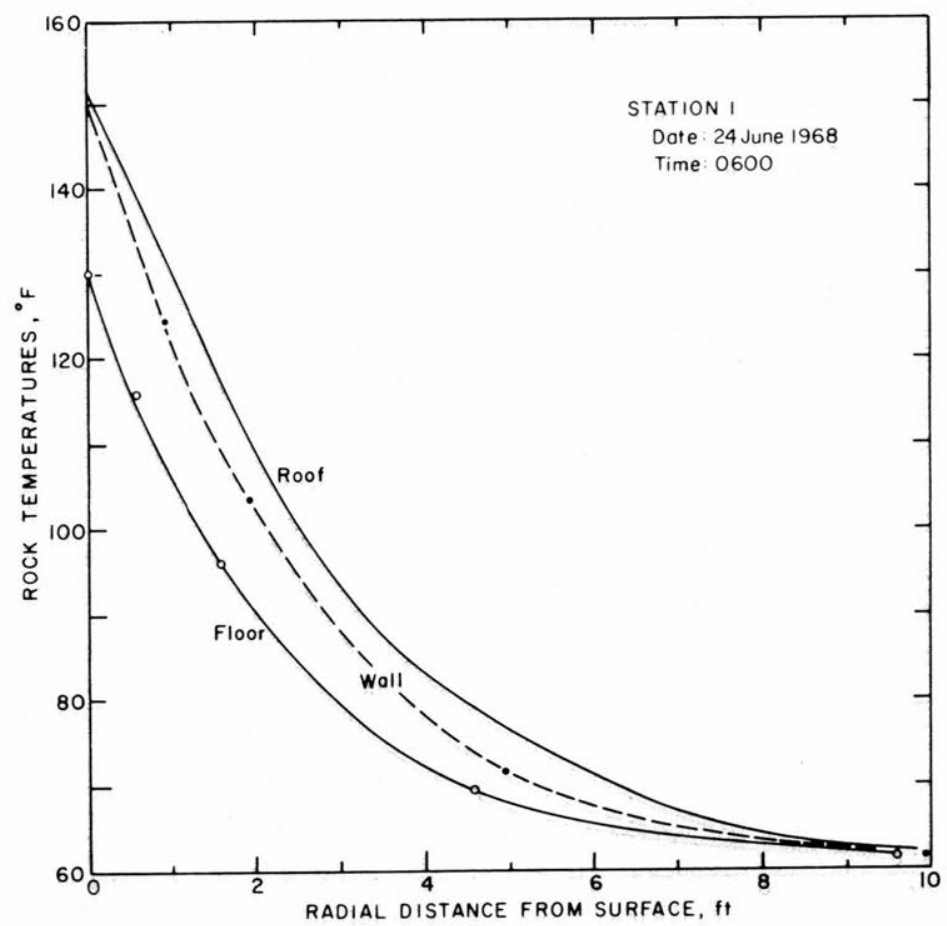

Figure 25. Radial distance vs temperature at station 1, 0600, 24 June 1.968

particularly cooler. The rapid rise and sudden lowering of roof air temperature on 18 June (Fig. 24a) resulted from the sudden change in distributing steam from pipe $X$ to pipe $Y$. The effect of height on temperature at station 1 is also depicted in Figure 25 which shows the measured temperatures in the floor, roof and wall at various radial distances from the surface. The variation in temperature at different stations is shown in Figure 26; radial gradients in the wall at stations 2 and 3 are in close agreement. The similarity in temperature gradients in the wall at stations 1 and 4 is believed to be due to end effects, because higher temperatures would be expected near the surface at station 4 which is within $22 \mathrm{ft}$ of the source of steam. An improvement in the heat transfer coefficient with time between the air and rock surface is indicated in Figure 27a which shows a continual decrease in the temperature difference with time between the air and rock surface at stations 1,2 and 3. An overall average temperature difference is given in Figure 27b. The primary reason for this decrease is attributed to the continuous reduction in the quantity of air in the test area. The relationship between the air and vapor pressure with time is shown in Figure 28 which was developed from measured air-vapor temperatures at station 3. Differences of only $2^{\circ}$ to $4^{\circ} \mathrm{F}$ were reached by 24 June after 6 days of steam injection (Fig. 27a), at which time the airvapor temperature had reached about $155^{\circ} \mathrm{F}$. The air pressure then amounted to $72 \%$ of the total chamber pressure.

The air temperature variation with time at station 3 is shown in Figure 29 together with the surface temperature of bulkhead B, $25 \mathrm{ft}$ from station 3 , and the temperature of the condensate leaving the tunnel. The air temperature increased from $60^{\circ} \mathrm{F}$ on 18 June to $200^{\circ} \mathrm{F}$ on 7 July (19 days). Starting on 8 July a distinct air cooling was recorded at station 3 and the same tendency was observed at the bulkhead. An explanation for this sudden drop in the heat ing carve was not obvious at that time. It was initially suspected that the steam rate had probably decreased; however, a comparison of feed-water rates indicates only a slight decrease in steam input between 7 and 18 July. The primary explanation for the cooling trend became evident after the test when the bulkhead door was opened and the rubble pile was observed. 


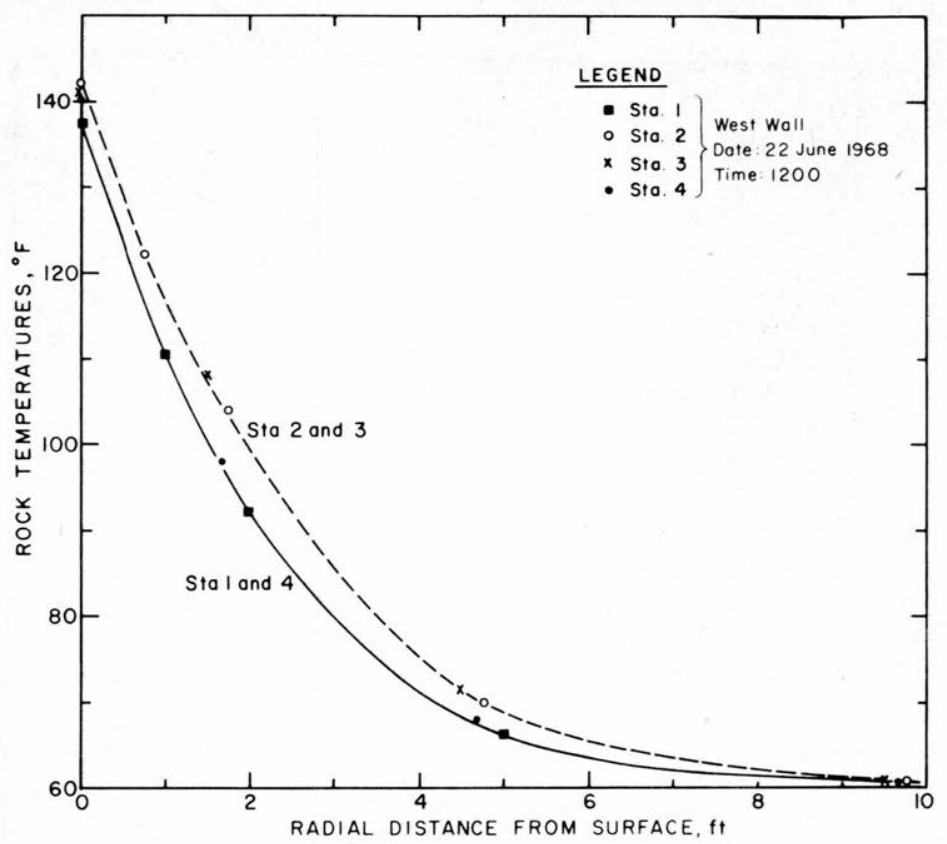

Figure 26. Radial distance vs temperature in the west wall, 1200, 22 June 1968.

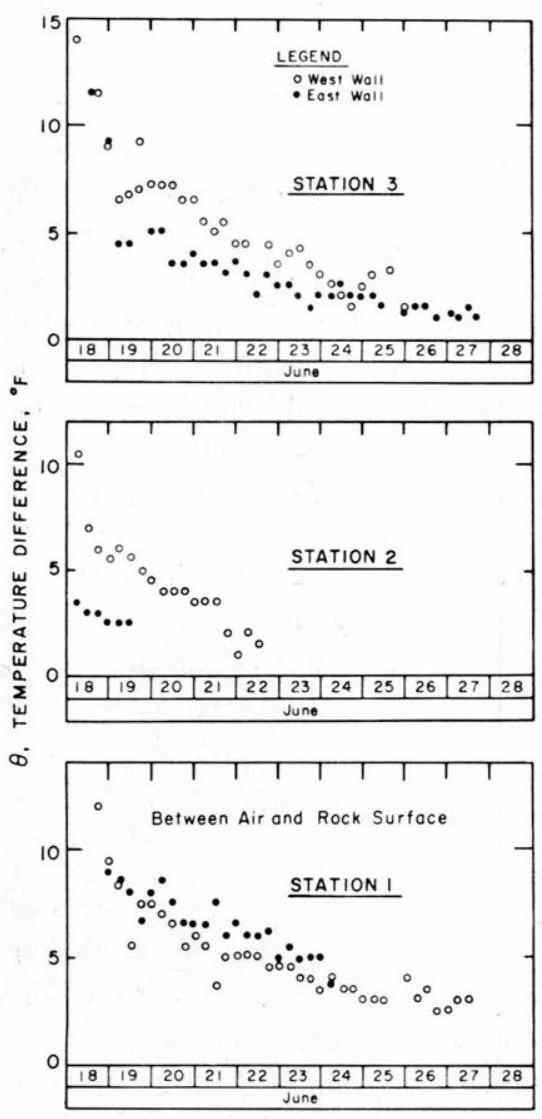

a. Stations 1,2 and 3 .

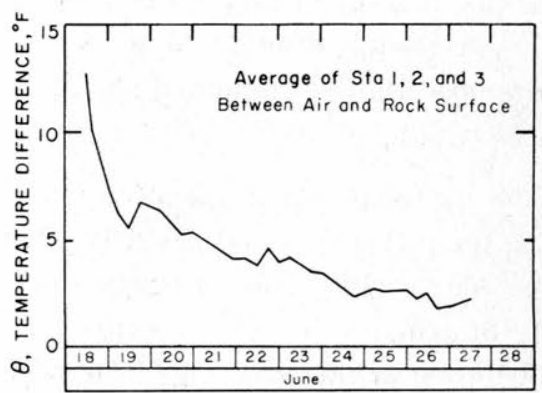

b. Average.

Figure 27. Temperature difference $\theta$ between air and rock surface. 


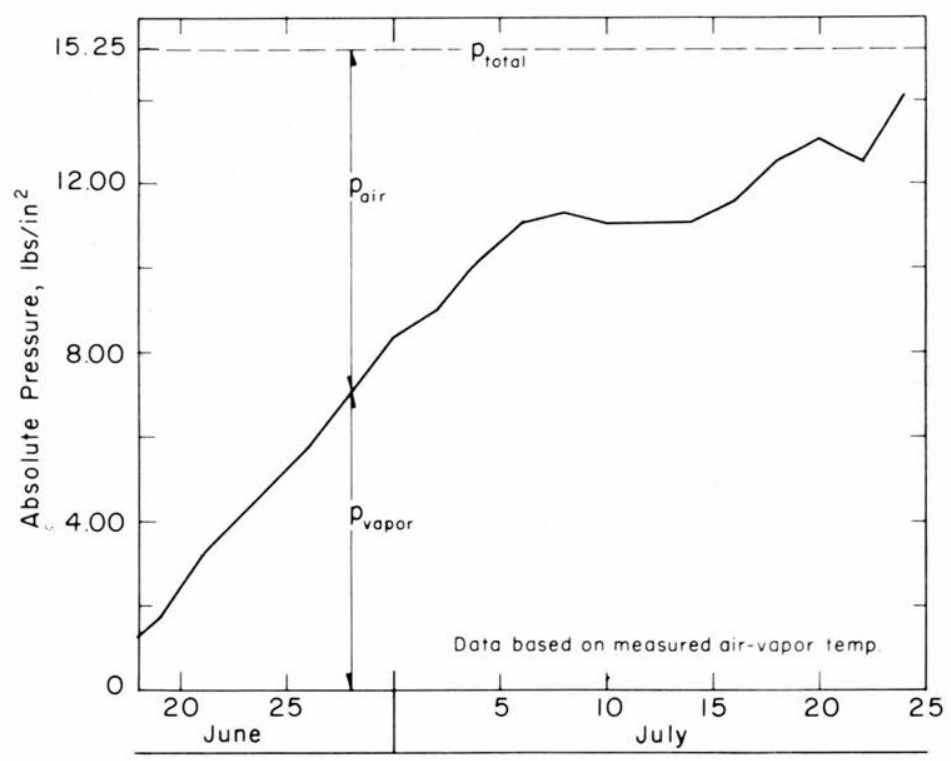

Figure 28. Vapor pressure vs time.

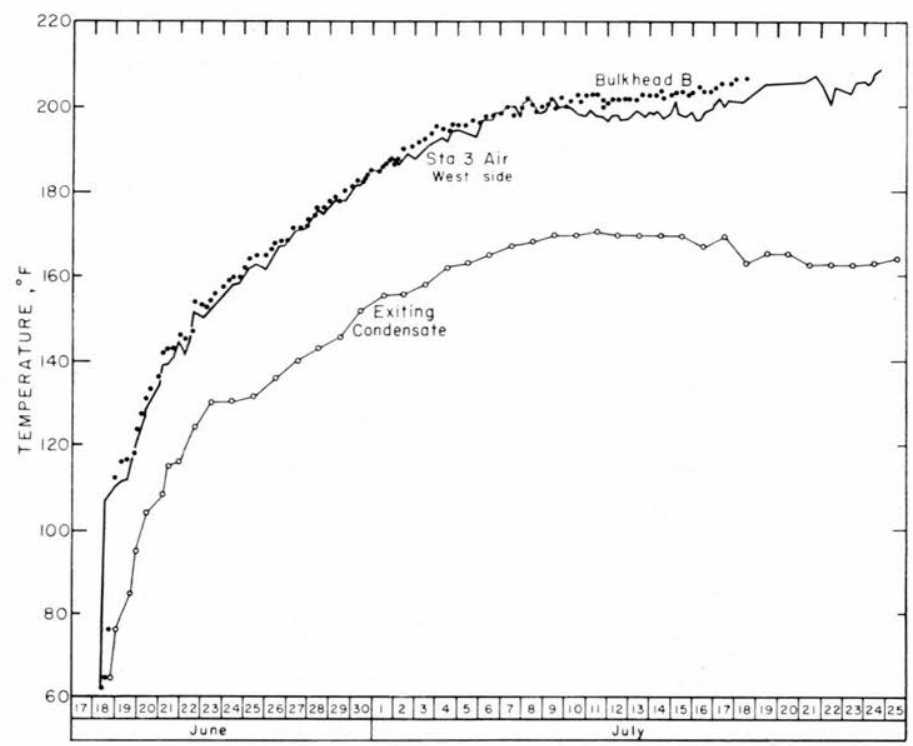

Figure 29. Measured temperature vs time (condensate, bulkhead $B$, station 3 air).

The event log maintained during the test cited numerous rock falls on 7 and 8 July and again on 17, 19, 20 and 21 July. This continual fall of roof rock exposed new, cooler surfaces for condensation and a larger mass for heating and thereby slowed the rate of heating of the tunnel atmosphere. Although it was evident that rock fall was taking place during the experiment, the magnitude of the fall was not fully appreciated until the test was completed.

Daily variations in weights of feed-water and condensate are given in Figure 30. Feed-water amounts were monitored with a standard house-totalizing water meter. Condensate was metered with a 55-gallon drum on a platform scale; the condensate was allowed to build up in the ditches which were then drained at approximately hourly intervals. The essentially constant difference 


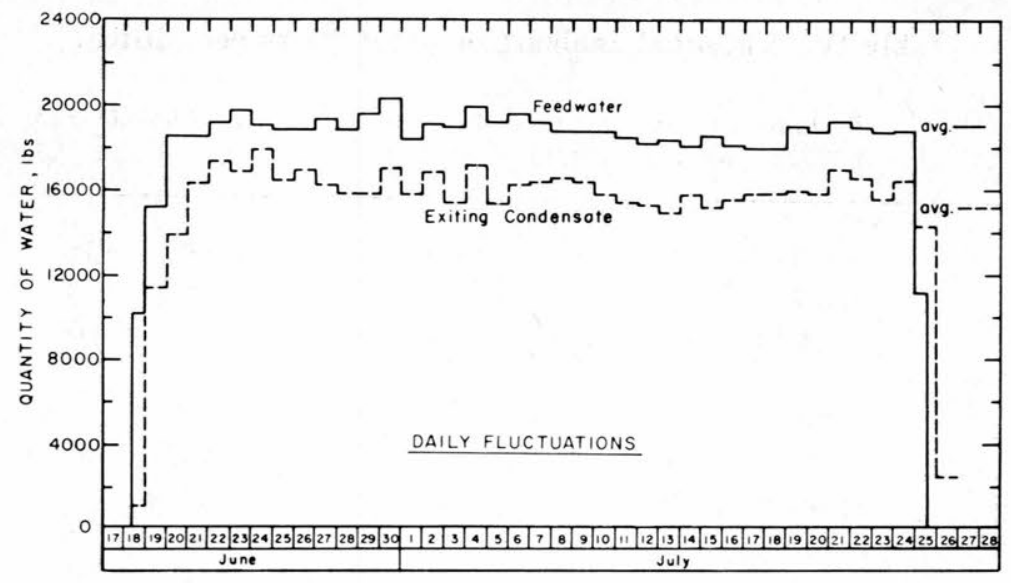

Figure 30. Daily fluctuations in feed-water and condensate quantities.

noted between the feed-water and condensate quantities (3000 lb/day) was initially believed due to calibration errors in either the platform scale or water meter. A calibration check on both devices indicated the platform scale underestimated condensate flow by only $0.7 \%$ and the water meter overestimated feed-water by only $0.5 \%$. These adjustments have been made in preparing Figure 30. Water losses between the water meter and the test area are due to boiler blow-down, and bleed-off at a pressure reducing valve. Boiler blow-down (twice a day) accounted for about $60 \mathrm{lb} /$ day and valve bleed-off for about $59 \mathrm{lb} /$ day. The heated air vented from the tunnel was water-trapped by a 1- to 2-in. column of water at room temperature. The air entered the water trap after passing through approximately $6 \mathrm{ft}$ of pipe which included a vertical rise of roughly $2 \mathrm{ft}$. Condensate which developed in the pipe flowed back into the test chamber; thus the venting process did not contribute to water loss. Condensate losses could have resulted from drainage of water through cracks in the rock beneath the bulkhead and subsequently into the mine drainage system. Roughly $500 \mathrm{lb}$ of condensate per day was collected on the boiler side of the bulkhead. Prior to initiating the test, an attempt was made to grout the joints in the rock beneath bulkhead B by placing a portland cement slurry on the tunnel floor and applying an air pressure of 2.5 psig to the tunnel atmosphere. The ballast was soaked with water prior to the start of the test to minimize the amount of condensate held in the ballast pores. Differences between the feed-water and condensate quantities were greatest during the early days of the test, indicating that some condensate was being held either in the ballast pores or in surface irregularities in the drainage ditches. It would appear that the water meter readings are a valid indication of the input and that condensate was lost by seepage through the rock and/or ballast into the mine drainage system.

Chemical analyses of the feed-water and condensate were performed by the Industrial Water Laboratory, Bureau of Mines; results of these tests are given in Table IV. The feed-water was slightly alkaline $(\mathrm{pH}=7.5)$ and became slightly more alkaline $(\mathrm{pH} 7.7$ to 8.3$)$ when returned as condensate. A comparis on between the chemical content of the feed-water and the condensate is difficult because the concentration of salts and minerals in the feed-water would tend to decrease during boiling and possibly increase during passage through pipes to the tunnel. Analyses of the condensate indicated a decreasing concentration of Calcium (Ca), Magnesium (Mg), Chloride (Cl), and Sulfate $\left(\mathrm{SO}_{4}\right)$ and an increasing concentration of Silica $\left(\mathrm{SiO}_{2}\right)$ with time. These observed variations were undoubtedly influenced by the continual exposure of new rock surface developed by spalling.

The quantity of heat introduced to the test area is itemized in Table V. The average daily boiler pressure was used to determine the enthalpy of steam in the boiler, and the temperature of 
Table IV. Chemical analysis of water, parts per million.

21 June 24 June 27 June $^{*} 27$ June 1 July 12 July 16 July 16 July $23 \mathrm{July}$

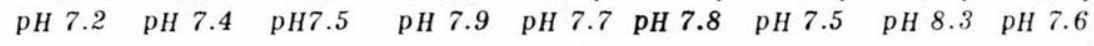

\begin{tabular}{|c|c|c|c|c|c|c|c|c|c|}
\hline $\mathrm{C}_{\text {alcium }}\left(\mathrm{C}_{\mathrm{a}}\right)$ & 119 & 66 & 79 & 51 & 39 & 30 & 78 & 30 & 34 \\
\hline Magnesium (Mg) & 7 & 2 & 5 & 4 & 3 & 4 & 7 & 2 & 2 \\
\hline Sulfate $\left(\mathrm{SO}_{4}\right)$ & 220 & 128 & 102 & 92 & 58 & 32 & 102 & 20 & 30 \\
\hline $\begin{array}{l}\text { Dissolved solids (DS) by } \\
\text { evaporation }\end{array}$ & & 720 & & & & 300 & & & \\
\hline Silica $\left(\mathrm{SiO}_{2}\right)$ & 27 & 34 & 13 & 34 & 37 & 43 & 13 & 44 & 50 \\
\hline Ratio of DS to conductivity & 71 & 0.78 & & & & 0.77 & & & \\
\hline Total alkalinity $\left(\mathrm{C}_{\mathrm{a}} \mathrm{CO}_{3}\right)$ & 150 & 140 & 133 & 150 & 150 & 153 & 133 & 150 & 163 \\
\hline Chloride $(\mathrm{Cl})$ & 61 & 43 & 22 & 50 & 32 & 14 & 21 & 6 & 26 \\
\hline $\begin{array}{l}\text { Specific conductance } \\
\quad\left(\text { micromhos } / \mathrm{cm} \text { at } 77^{\circ} \mathrm{F}\right)\end{array}$ & 1475 & 925 & 575 & 850 & 600 & 390 & 550 & 310 & 475 \\
\hline Soluble iron $(\mathrm{Fe})$ & & & & & & & & 0.3 & \\
\hline
\end{tabular}

* Feed-water - all others condensate

Table V. Determination of heat input.

Column (4) (3) $\times[(1)-(2)]:(13.800)(24):$ Heat added using feed-water quantities. Column $(6)=(5) \times[(1)-(2)]:(13.800)(24):$ Heat added using condensate quantities.

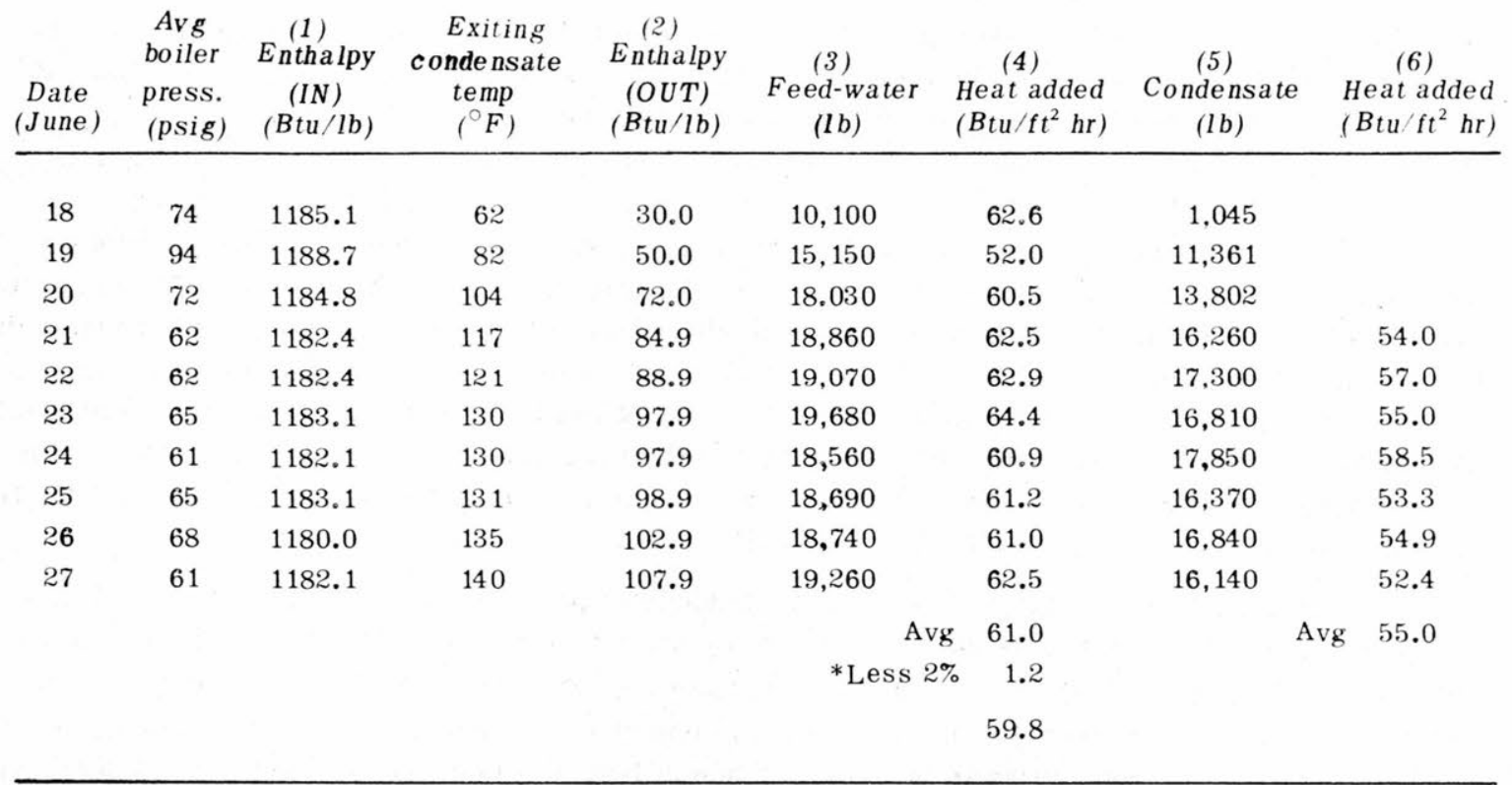

* Adjustment for end losses and steam quality. 
Table VI. Period of temperature record.

\begin{tabular}{|c|c|c|c|c|c|}
\hline \multirow[t]{2}{*}{ Location } & \multicolumn{2}{|c|}{$\begin{array}{l}\text { Period of record } \\
\text { (From 18 June) }\end{array}$} & \multirow[t]{2}{*}{ Location } & \multicolumn{2}{|c|}{$\begin{array}{l}\text { Period of record } \\
\text { (From } 18 \text { June) }\end{array}$} \\
\hline & & & & & \\
\hline$R_{\text {oof }}$ & 28 June & 10 days & $R_{\text {oof }}$ & 18 June & 0 days \\
\hline West wall & 29 June & 11 & West wall & 21 June & 33 \\
\hline East wall & 2s June & 11 & West wall (surface) & 27 June & 9 \\
\hline East wall (air and surface) & 8 July & 20 & East wall & & Full term \\
\hline Floor & 24 June & 6 & East wall (5 ft) & 8 July & 20 \\
\hline Station 2 & & & East wall $(10 \mathrm{ft})$ & 28 June & 10 \\
\hline$R_{\text {oof }}$ & 20 June & 2 days & Floor & 18 June & 0 \\
\hline West wall & 23 June & 5 & Station 4 & & \\
\hline East wall & & Full term & Roof & 19 June & 1 \\
\hline East wall (air and surface) & 20 June & 2 & West wall & & Full term \\
\hline Floor & 22 June & 4 & East wall & & Full term \\
\hline & & & Floor & 30 June & 12 \\
\hline
\end{tabular}

the returning condensate was used for computing the residual heat in the water leaving the test area. In order to establish maximum and minimum rates of heat transfer, both feed-water and condensate quantities are used to permit a comparative analysis. The resulting average heat input, assuming a $13,800-\mathrm{ft}^{2}$ surface area, varies between 55 and $60 \mathrm{Btu} / \mathrm{ft}^{2} \mathrm{hr}$. The total heat lost by venting air from the chamber amounted to $106 \times 10^{3} \mathrm{Btu}$ and the heat remaining in the vapor-filled tunnel atmosphere at the completion of the test was on the order of $1600 \times 10^{3} \mathrm{Btu}$. The combination of these heat quantities represents slightly over 2 hours of boiler production or $0.24 \%$ of the total heat added during the course of the test.

A comprehensive assessment of test results was complicated by the frequent loss of temperature sensors which occurred continuously throughout the test. The period of record for each of the 16 thermocouple assemblies installed in the rock is listed in Table VI.

The test was terminated on 25 July before the rock surface reached the saturation temperature of $213.8^{\circ} \mathrm{F}$. The decision to prematurely terminate the test was the result of two factors: 1) the mine was scheduled to shut down for a month on 26 July, and 2) the slow warming rate in the chamber influenced by rock fall made the estimation of a possible termination date unpredictable. As previously mentioned, stress meters were installed; however, because of rock fall, no readings were possible at the completion of the test.

\section{ANALYSIS}

\section{Surface transfer coefficients}

As shown in Figure 27a, temperature differences between the air-vapor and rock surface decreased with time, thereby indicating an increase in the combined surface transfer coefficient.

For a temperature difference of $4^{\circ} \mathrm{F}$ and heat input rates of 55 to $60 \mathrm{Btu} / \mathrm{ft}^{2} \mathrm{hr}$, a combined surface transfer coefficient on the order of 13 to 15 is indicated. During the early days of the test, temperature differences of $6^{\circ}$ to $8^{\circ} \mathrm{F}$ were observed, representing coefficients of 7 to $10 \mathrm{Btu} / \mathrm{ft}^{2} \mathrm{hr}{ }^{\circ} \mathrm{F}$.

In a design analysis for predicting warmup time to reach saturation, the governing factor is the rock surface temperature (dewpoint), which establishes the vapor pressure in the chamber. 
When this temperature equals the saturated vapor temperature, corresponding to atmospheric pressure, the heat acceptable by the rock is in balance with the heat introduced into the chamber. The continued introduction of heat at the same constant rate subsequent to this time will result in pressurization of the chamber or the overflow of steam into the vent system. By making several assumptions, the warmup time can be approximated by mathematically establishing the relationship between rock surface temperature and time. The magnitude of the combined surface transfer coefficient will not significantly affect the time for the rock surface to reach the saturated steam temperature; however, it will have a major effect upon the rate of temperature rise of the air-vapor mixture. Although the relationship between rock surface temperature and time is not affected by the surface transfer coefficient, the chamber temperature is absolutely dependent on this coefficient. Surface transfer coefficients are important in predicting the rate at which air will be ejected from the chamber in order to maintain a constant pressure or to predict the rate at which chamber pressure will develop in the event that air is not ejected.

\section{Measured vs predicted surface temperature}

Establishing a correlation between measured and predicted temperature was complicated by the problem of rock fall which retarded the rate of temperature rise. In comparing actual with theoretical values, the mathematical model must be kept in mind. The model assumes uniform radial heat flow over the entire surface area of a hollow cylinder and a constant inner radius. In this experiment, the heat flow was not strictly radial because the cooler condensate drained along the floor and the inner radius was not constant due to spalling of the roof and walls. Also the initial tunnel cross section was rectangular rather than circular. Had roof spall not occurred, the air temperatures would have increased more rapidly than observed.

An indication of the significance of rock fall, both in terms of magnitude and time, may be obtained from Figure 29. Two discontinuities are evident in the relationship between condensate temperature and time. Between 23 and 25 June the condensate temperature remained relatively constant while the tunnel air temperature continued to increase. From about 9 to 17 July the condensate temperature remained nearly constant, after which it tended to decrease (except for 16 July). A possible explanation for this behavior is that the condensate, in flowing past the rock rubble on the tunnel floor, was giving up some of its heat to the numerous rock slabs (with their associated high surface areas). The decrease in air temperature on the west wall at station 3 and the leveling out of the bulkhead B temperature probably indicate a substantial rock fall within the test area subsequent to about 9 July. The exposure of a significant amount of cooler rock surface could explain the cooling trend in the condensate observed during the final two weeks of the experiment. The slope of the condensate temperature vs time curve up to about 23 June indicates that substantial rock fall probably did not develop prior to that time.

As previously discussed, the temperature gradient in the floor differed from those observed in the wall and/or roof (Fig. 24b). The heat stored in the rock surrounding station 1 was estimated using the radial distance-temperature curves given in Figure 25 for 0600 on 24 June. This amounted to an average heat flux of $77 \mathrm{Btu} / \mathrm{ft}^{2}$ hr to the roof, $69 \mathrm{Btu} / \mathrm{ft}^{2} \mathrm{hr}$ in each wall and $44 \mathrm{Btu} / \mathrm{ft}^{2}$ in the floor. Although these values are only approximations of the heat budget, they do indicate that heat storage in the floor was considerably less than in the walls or roof during the early stages of the experiment and prior to the rock fall.

The heat flux to the floor, in addition to condensation, also includes some sensible heat as the condensate temperature was always less than that of the vapor-air mixture (Fig. 29). The temperature difference between the vapor-air mixture at station 1 and the exiting condensate is on the order of $20^{\circ} \mathrm{F}$ and for an average stream flow rate up to 24 June of $750 \mathrm{lb} / \mathrm{hr}$ (see Table V), this represents a relatively small average heat flux to the floor of about $4 \mathrm{Btu} / \mathrm{ft}^{2} \mathrm{hr}$ due to extraction of sensible heat from the condensate water. Subtracting this amount from 44 results in about 


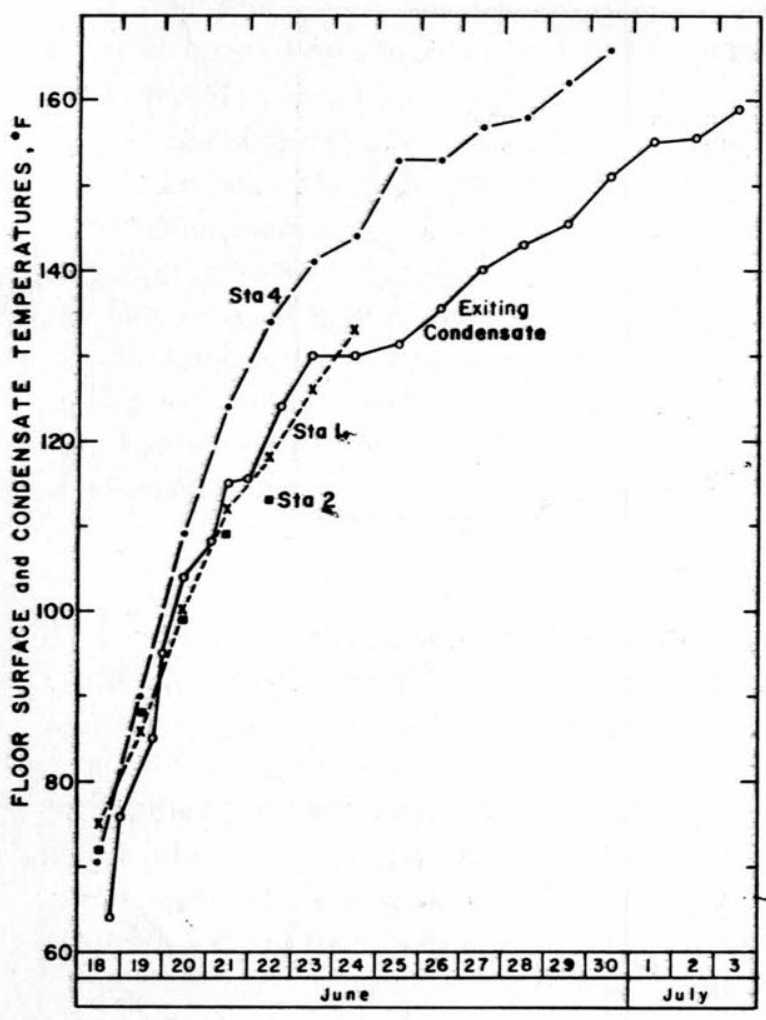

Figure 31. Floor surface and condensate temperatures vs time.

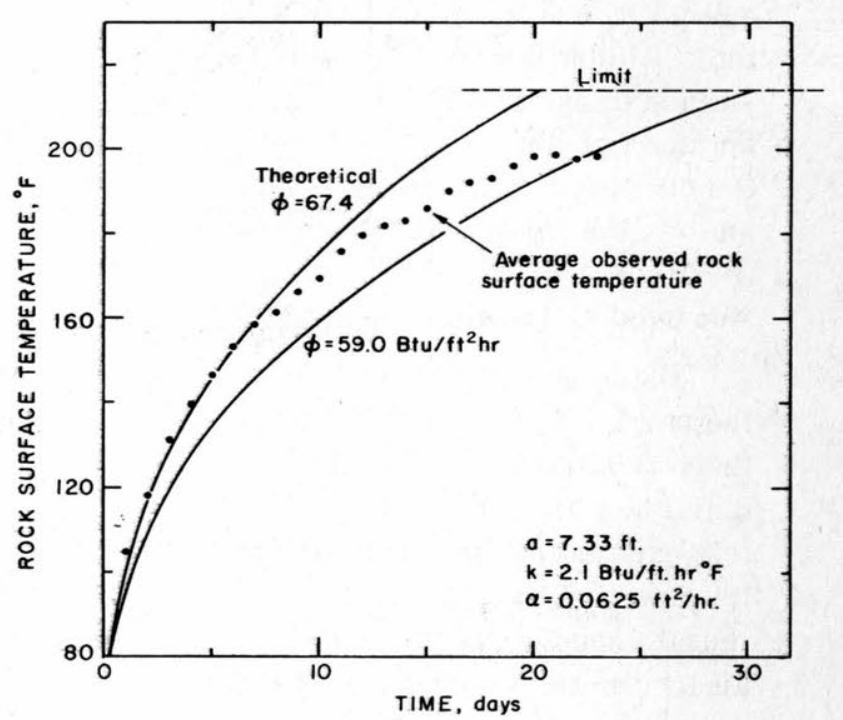

Figure 32. Adjusted theoretical surface temperaturetime relation ship.

a $40 \mathrm{Btu} / \mathrm{ft}^{2} \mathrm{hr}$ heat flux to the floor attributable to change of state. This lower heat transfer to the floor was due to a combination of factors: 1) the temperature "stratification" existing in the tunnel, which represented an air-rich mixture of air and vapor near floor level and consequently a poorer transfer condition, 2) the insulating effect of the water layer flowing along the floor, and 3) the gradual buildup of fallen rock. A comparison of the floor surface temperatures at stations 1,2 and 4 with the exiting condensate temperature is given in Figure 31. There is reasonably good agreement between the condensate temperature and floor surface temperatures at stations 1 and 2 during the early stages of the test. This indicates that the loss of heat by the condensate to rock rubble was probably not significant during the early stages of the test. The higher floor surface temperature at station 4 was probably the result of its proximity to the region of steam discharge.

Figure 32 compares the average measured rock surface temperature vs time with the theoretical curve, assuming a flux of $59 \mathrm{Btu} / \mathrm{ft}^{2} \mathrm{hr}$. The measured temperatures are greater than predicted during the early portion of the test although they do intersect after about 22 days. As previously mentioned, the exposure of cool rock surface due to spalling resulted in prolonging the warmup period over what it would have been had no spalling developed. It would therefore appear that the mathematical model tends to overpredict warmup times, a situation that is undesirable for the purposes of this application. Analytical predictions of the time required for the rock surface to reach the limiting temperature must be modified to account for the relatively slow heat transfer to the floor. Such adjustment can be most easily applied theoretically by reducing the amount of surface area exposed for heat transfer or in effect increasing the heat flux. The deletion of $40 \%$ of the floor area results in a revised heat flux of $67.4 \mathrm{Btu} / \mathrm{ft}^{2} \mathrm{hr}$ which is $12.7 \%$ greater than the heat flux determined using feed-water quantities and the entire surface area (Table V). A theoretical curve 


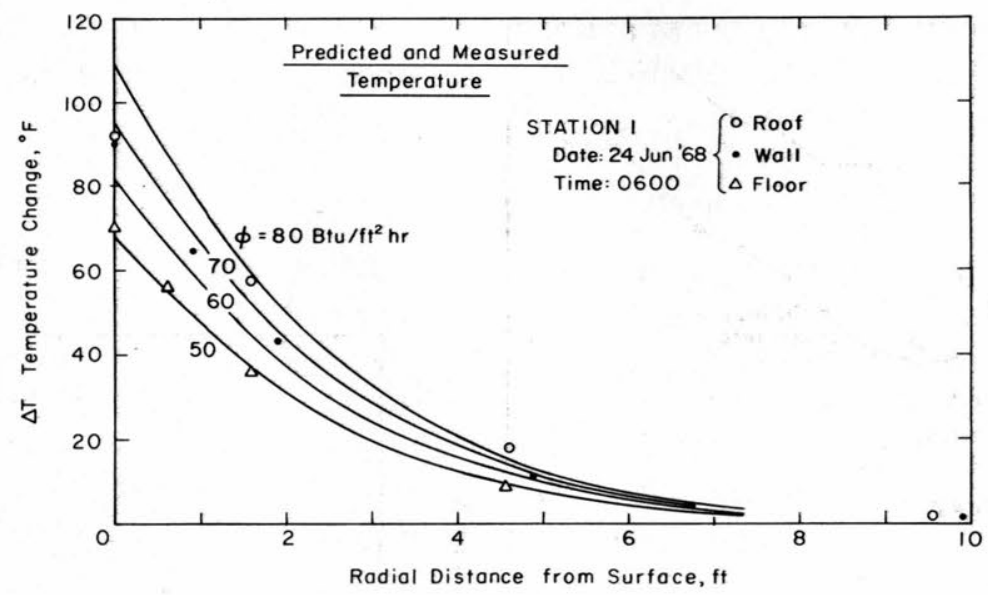

a. Temperatures at various radial distances, station 1 , 0600, 24 June 1968.

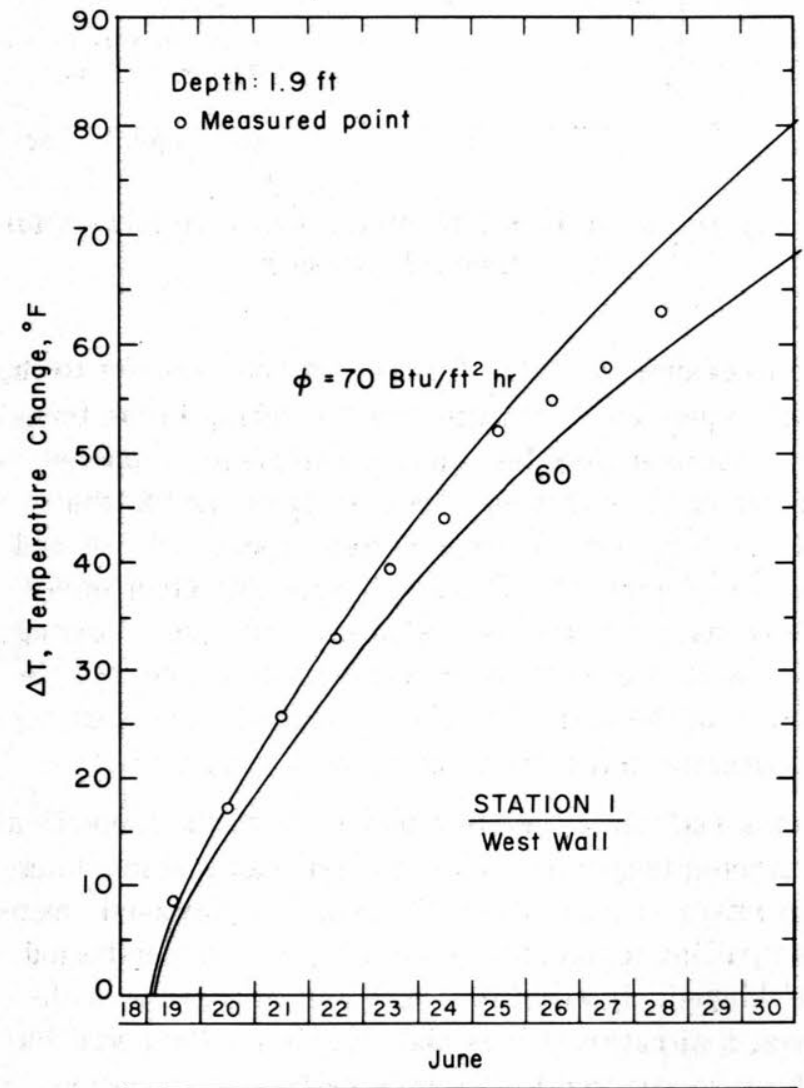

b. Temperature vs time, station 1 , west wall.

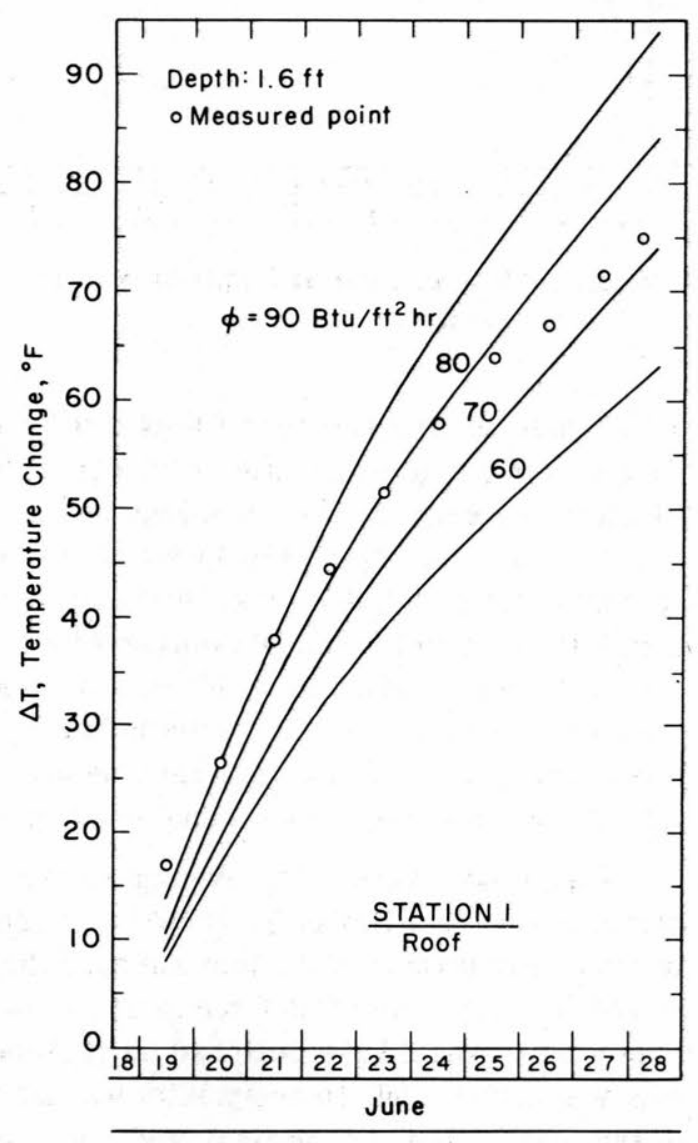

c. Temperature vs time, station 1 , roof.

Figure 33. Comparison of predicted and measured rock temperatures. 
(Fig. 32), so adjusted, is compared with average surface temperatures measured in the walls and roof at stations 1,2 and 3. The departure from the theoretical curve on the 8 th day undoubtedly represents the influence of rock fall.

\section{Measured vs predicted radial gradients}

A comparison of measured and predicted radial gradients is shown in Figure 33a for station 1 using data from Figure 25. The measured wall gradient parallels the predicted gradients for heat fluxes of 60 and $70 \mathrm{Btu} / \mathrm{ft}^{2} \mathrm{hr}$. Figure 33b compares predicted and measured temperature change vs time for a depth of $1.9 \mathrm{ft}$ in the wall at station 1 (this depth corresponds to the location of a thermocouple). Again the radial flow model appears to be a realistic representation for this location. The higher measured temperatures during the early stages of the test undoubtedly reflect the departure from a radial heat flow pattern due to the rectangular shape of the tunnel. The radial gradient in the roof does not parallel the predicted gradients, indicating the possibility of a time variation in heat flux to the roof. Comparisons between predicted and measured temperature change with time for a depth of $1.6 \mathrm{ft}$ in the roof are given in Figure 33c. Indications of a high initial flux to the roof may be inferred from this chart. The high heat load to the roof during the early stage of the experiment was also indicated in Figure 24a. Although rock fall had a substantial effect on heat flow patterns, the writers consider that the successful application of radial flow theory to the wall at station 1 should also apply (for the same time interval) to the roof at that station.

\section{Water-filled vs vapor-filled tunnel}

The inherent advantage of the concept tested in this experiment is that it permits tunnel space to be used for access as well as for heat storage. Thus the major expense of constructing such tunnels is not incurred as a heat sink expense. Tunnel use for access subsequent to use as a heat sink may be complicated by the high temperatures that will exist. Should it be determined that heat sinks must be developed separately and that access tunnels may not be used, it would then be desirable to consider filling the heat sink tunnels with water and thereby take advantage of heat storage by both the water and the surrounding rock. A theoretical comparison of heat flux versus warmup time for both vapor-filled and water-filled tunnels is given in Figure 34 . The tunnel used for this comparison is identical to that used to develop the relationship for the Mineville experiment (Fig. 12). For the same warmup period of 20 days, a flux of roughly $110 \mathrm{Btu} / \mathrm{ft}^{2} \mathrm{hr}$ could have been used, which is 1.8 times greater than the heat flux selected for this experiment.

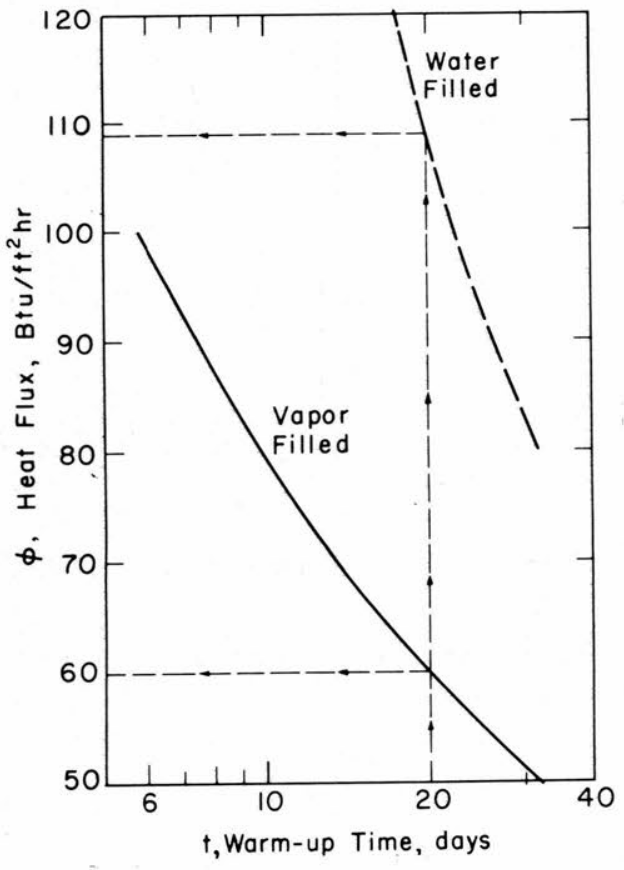

$\mathrm{k}=1.7 \mathrm{Btu} / \mathrm{fthr}{ }^{\circ} \mathrm{F}$

$a=0.050 \mathrm{ft}^{2} / \mathrm{hr}$

$a=7.33 \mathrm{ft}$

$\Delta T=212-60=152^{\circ} \mathrm{F}$

Figure 34. Heat flux vs warmup time for vapor-filled and water-filled tunnels. 


\section{CONCLUSIONS}

A comparison between the theoretical and measured results is particularly difficult because of the rock fall which occurred throughout the test, but the following conclusions can be drawn from the results of this experiment.

1. An unlined tunnel constructed by drilling and blasting was the primary cause of slabbing in the roof. The following expedients would reduce, or possibly eliminate, this effect: lining the tunnel, using rock bolts or roof screening, or machine-boring the tunnel. The test did show that using steam in an unstable cross section like the rectangular, drilled and blasted tunnel used in this experiment could result in serious rock fall problems. Some of the rock fall occurred early in the test at a time when air temperatures had reached only about $100^{\circ} \mathrm{F}$. A machine-bored tunnel would have had a much more stable geometric shape and the boring operation would probably not cause the extensive fracturing that results from typical blasting procedures.

2. As indicated in the figures, the longitudinal distribution of steam within the $300-\mathrm{ft}$ test area was remarkably uniform. Although most thermocouples at the far end of the tunnel were eventually lost, the uniform mixing during the early stages of the test was readily demonstrated by measurement. An air temperature observation was available at station 1 up until 8 July (20 days). The average longitudinal temperature variation amounted to $6^{\circ}$ to $8^{\circ} \mathrm{F}$ in $300 \mathrm{ft}$. The total pressure in the tunnel was maintained at atmospheric by continuously venting heated air; thus the drop in steam supply line pressure remained constant at about $10 \mathrm{psi}$. Rock falling on the discharge pipe caused an unknown decrease in this differential.

3. The heat transfer coefficient between rock and air mixed with steam is at least ten times as great as that between rock and air alone. The continued improvement in heat transfer was primarily due to the venting of air throughout the test. Had a vacuum been established at the start of the test, heat transfer would have been more rapid initially but this would have had no effect on the total warmup time. One consideration in extending the warmup time period would be to allow a slight pressure (above atmospheric) to develop in the chamber. The effect of this modification would be to increase the maximum condensing temperature. A theoretical relationship between warmup time and pressure (above atmospheric) is given in Figure 35.

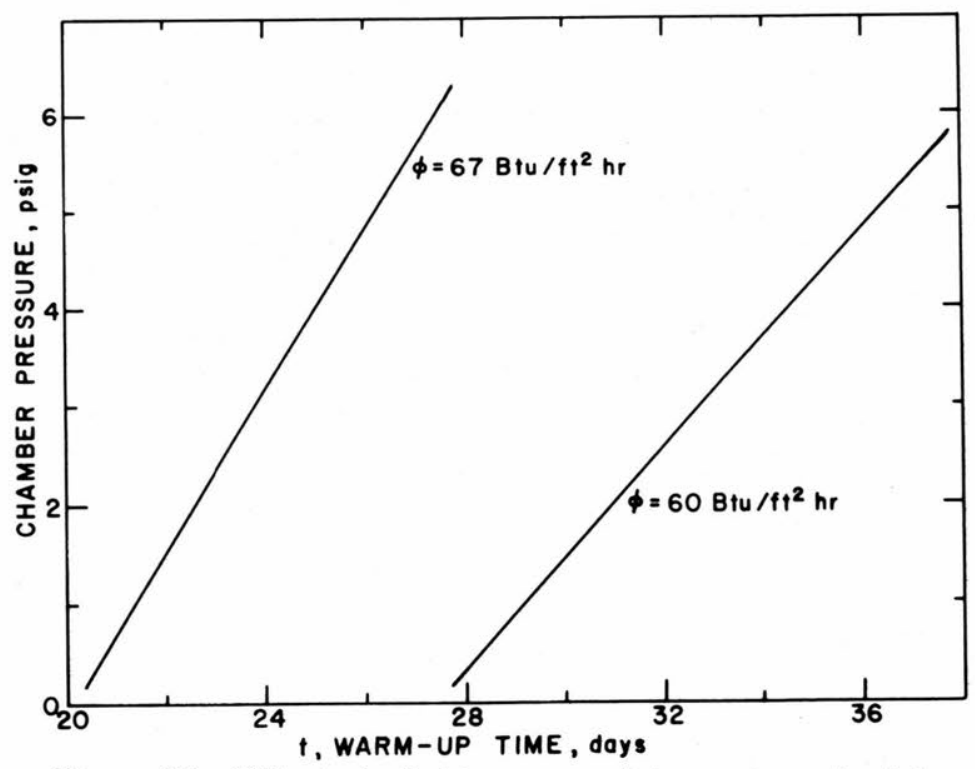

Figure 35. Effect of slight pressure (above atmospheric) on warmup time extension. 
4. Heat transfer to the floor was less than that to either the walls or roof. This resulted in two unfavorable conditions: 1) a departure from radial flow, causing a decrease in warmup time, and 2) the greater extraction of heat from returning condensate. A desirable goal would be to extract only the heat of condensation and no sensible heat from the steam-condensate as the condensate would be reused as feed-water in the power cycle.

5. Analytical predictions of the time required for the rock surface to reach the condensing temperature must be modified to account for the relatively low heat transfer coefficient at the floor. Such an adjustment can be most easily made by reducing the amount of surface area exposed for heat transfer, i.e. increasing the heat flux. For this particular test, an increase in flux of 13 to $15 \%$ would have been an appropriate adjustment. Although such an adjustment is considered to be conservative, full-term validation was not possible in this field experiment.

6. In the event that rock debris can be tolerated in either all or a portion of the tunnel space, the advantageous use of spalled rock for additional heat sink capacity was made obvious by this experiment.

7. Water-filled tunnels provide an attractive alternative to vapor-filled tunnels in the event that personnel access is not a requirement.

\section{RECOMMENDATIONS}

1. This experiment was conducted primarily to compare theoretical with actual warmup time for a steam-air mixture to reach the saturated steam temperature associated with atmospheric pressure. It was not the intent of the test to evaluate a steam distribution system. From the standpoint of economy and structural integrity (least amount of hardware), a strong reliance on free convection is desirable. However, in the design of such a distribution system the spacing and sizing of steam discharge points must be established, as well as the pressure differentials required to move steam long distances within a tunnel complex. The disposition of tunnel air must be considered. In this test, the evacuated air was dumped into the atmosphere. Under the button-up mode as formulated for this experiment, such dumping would not be possible in the prototype and thus a provision must be made to store evacuated air under pressure below ground. It is recommended that the problem of steam distribution and condensate collection be studied analytically and that a scale model experiment be conducted to simulate the "button-up" condition.

2. The prime difficulty involved in analyzing the results of this test was the consideration of the effects of rock fall. Due to this continuous fall, the tunnel never reached saturated steam temperature; also, thermocouple data (including differences between the air and rock at various locations) were lost during the test. At the conclusion of the test only $25 \%$ of the installed thermocouples were still functioning. Following the completion of the study recommended above, the writers consider that a final determination on this concept would greatly benefit from an additional field test that would be conducted in a machine-bored and lined, or well-reinforced (bolted) unlined, tunnel. Such a test would involve a longer tunnel and would permit evaluation of the steam distribution - condensate collection system in addition to providing more comprehensive heat transfer information. 


\section{LITERATURE CITED}

1. Birch, F. (1950) Flow of heat in the Front Range, Colorado. Bulletin of the Geological Society of America, vol. 61, p. 567-630.

2. Blomstran, W. (1968) Personal communication. District Manager, Republic Steel Adirondack Ore Mines, September 1968.

3. Carslaw, H.S. and J.C. Jaeger (1959) Conduction of Heat in Solids. London: Oxford University Press, p. 338.

4. Clarke, S.P. Jr. (1966) Handbook of Physical Constants. The Geological Society of America, Inc.

5. Cook, J.B., J.W. Libby and J.T. Madill (1962) Kemano Tunnel operation and maintenance. The Engineering Journal of the Engineering Institute of Canada, vol. 45, no. 8 , p. $39-47$.

6. Department of the Army (1965) Heating and Air Conditioning of Underground Installation. Technical Manual TM 5-855-4.

7. Dill, R.S. and B.A. Peavy (1956) Some observations on the use of underground reservoirs as heat sinks. National Bureau of Standards Report 4795.

8. Farrell, P.F. (1968) Mine development. Mining Congress Journal, vol. 54, no. 3, p. 54-56.

9. Hubbard, F.R. III (1967) Tunnel condenser concept (U). Nuclear Power Field Office, Ft. Belvoir, Virginia (CONFIDENTIAL).

10. Karr, D., J. Wilhelm and M. Greenberg (1969) Mechanical design of the heat sink field test. U.S. Army Cold Regions Research and Engineering Laboratory (USA CRREL) Technical Note (unpublished).

11. Kent (1950) Kent's Mechanical Engineer's Handbook. New York: Wiley and Sons, 12 th edition.

12. Parsons, Brinckenhoff, Hall and MacDonald (1958) Feasibility study - Ic ing of underground reservoirs (U). Project DOD-55-VAR for the U.S. Army Corps of Engineers (SECRET).

13. Peavy, B.A. and R.S. Dill (1956) Heat absorbing capacity of an underground reservoir used as a heat sink. National Bureau of Standards Progress Report 4740.

14. Quinn, W.F. and M. Greenberg (1967) A study of the steam heat sink concept (U). USA CRREL Report (SECRET).

15. Stanley, L.E. and G.E. Fellers (1969) Temperatures in an infinite medium surrounding a cylindrical constant heat flux. USA CRREL Technical Note (unpublished).

16. Tien, C. (1960) Analysis of a sub-ice heat sink for cooling power plants. U.S. Army Snow, Ice and Permafrost Research Establishment (USA SIPRE) Research Report 60 . AD 696399 .

17. USA CRREL (1966) Studies of underground heat sink concept (U). USA CRREL Draft Report (unpublished) (SECRET). 


\section{APPENDIX: TABULATION OF THEORETICAL ROCK TEMPERATURES}

\section{Conditions}

A hollow cylinder in an infinite medium, both at the same temperature.

Constant thermal properties in the medium.

Constant heat flow through the cylinder surface.

\section{Solution ${ }^{15}$}

Temperature change in the medium:

$$
\Delta T=-\frac{2 \phi}{\pi k} \int_{0}^{\infty} \frac{\left(1-\mathrm{e}^{-a u^{2} t}\right) J_{0}^{(u r) Y_{1}(u a)-Y_{0}(u r) J_{1}(u a)}}{u^{2}\left[J_{1}^{2}(u a)+Y_{1}^{2}(u a)\right]} d u .
$$

Transformation by setting $V=a u$ and $n=r / a$ :

$$
\Delta T=-\frac{2 \phi \mathrm{a}}{\pi k} \int_{0}^{\infty} \frac{\left(1-\mathrm{e}^{\left.-\left(\alpha t / \mathrm{a}^{2}\right) V^{2}\right)}\right.}{V^{2}} \cdot \frac{J_{0}(n V) Y_{1}(V)-Y_{0}(n V) J_{1}(V)}{J_{1}^{2}(V)+Y_{1}^{2}(V)} d V
$$

Dimensionless form:

$$
\Delta T \cdot \frac{k}{a \phi}=f\left(\frac{a t}{a^{2}}\right) .
$$

\begin{tabular}{|c|c|c|c|}
\hline a & $=$ & Cvlinder radius & $\mathrm{Ft}$ \\
\hline$C$ & $=$ & $a t / a^{2}$ & Dimensionless \\
\hline$c_{p}$ & $=$ & Specific heat of rock & $\mathrm{Btu} / \mathrm{lb}{ }^{\circ} \mathrm{F}$ \\
\hline$J, Y$ & $=$ & Bessel functions & \\
\hline$k$ & $=$ & Coefficient of thermal conductivity of rock & $\mathrm{Btu} / \mathrm{ft} \mathrm{hr}{ }^{\circ} \mathrm{F}$ \\
\hline$n$ & $=$ & $r / a$, radius ratio & Dimensionless \\
\hline$r$ & $=$ & Radial distance & $\mathrm{Ft}$ \\
\hline$t$ & $=$ & Time & $\mathrm{Hr}$ \\
\hline$a$ & $=$ & Coefficient of thermal diffusivity $=k / \rho c_{p}$ & $\mathrm{Ft}^{2} / \mathrm{hr}$ \\
\hline$\Delta T$ & $=$ & Temperature change & ${ }^{\circ} \mathrm{F}$ \\
\hline$\phi$ & $=$ & Heat flux density & $\mathrm{Btu} / \mathrm{ft}^{2} \mathrm{hr}$ \\
\hline$\rho$ & & Density of rock & $\mathrm{Lb} / \mathrm{ft}^{3}$ \\
\hline
\end{tabular}

Nomenclature: 
Table I. Computer printout of $f(c)$ for radius ratios of $1,1.25,1.50,1.75,2,4,6,8,10$ (from Stanley and Fellers ${ }^{15}$ ).

While the ranges of $C$ and $n$ were originally selected on the basis of need, as the tables were developed the numerical values indicated that the initial and terminal values of $C$ should be altered for various values of $n$. For small $n$ the $C$ scale was expanded, and as $n$ increased the $C$ scale was compressed. Thus there are five tables for $n=1$ and only two for $n=10$.

$\begin{array}{ll}C & .0000 \\ .000 & .0000 \\ .001 & .035 \\ .002 & .0495 \\ .003 & .060 \\ .004 & .0695 \\ .005 & .077 \\ .006 & .0846 \\ .007 & .091 \\ .008 & .0972 \\ .009 & .1028\end{array}$

$\begin{array}{lll}.0001 & .0002 & .0003 \\ .0115 & .0159 & .0194 \\ .0369 & .0385 & .0401 \\ .0507 & .0519 & .0530 \\ .0613 & .0623 & .0633 \\ .0703 & .0711 & .0720 \\ .0782 & .0789 & .0796 \\ .0853 & .0859 & .0866 \\ .0917 & .0924 & .0930 \\ .0978 & .0983 & .0989 \\ .1034 & .0039 & .1045\end{array}$

.0004
.0224
.0415
.0541
.0642
.0728
.0804
.0873
.0936
.0995
.1050

.0005
.0250
.0430
.0552
.0651
.0730
.0811
.0879
.0942
.1001
.1055

.0006
.0274
.0444
.0563
.0660
.0744
.0818
.0886
.0948
.1006
.1061

.0007
.0295
.0457
.0573
.0669
.0751
.0825
.0892
.0954
.1012
.1066

.0008

. vouy

.0312

. USग4 $.04 / 4.0405$ .0584 .ujya $.06 / 8$. $.075 y \quad .0101$ .0832 . .u8sa .08ga .ugus $.0 y 00$.uy0o .1011 .023 $.1071 \quad .1011$

$\begin{array}{ll}C & .0000 \\ .000 & .0000 \\ .010 & .1082 \\ .070 & .1504 \\ .070 & .1819 \\ .040 & .2079 \\ .050 & .2303 \\ .060 & .2502 \\ .070 & .2683 \\ .000 & .284 \\ .000 & .3002\end{array}$

$\begin{array}{lll}.0010 & .0020 & .0030 \\ & & \\ .0352 & .0495 & .0604 \\ .1132 & .1180 & .1226 \\ .1539 & .1573 & .1607 \\ .1847 & .1875 & .1902 \\ .2102 & .2126 & .2149 \\ .2324 & .2345 & .2365 \\ .2521 & .2540 & .2558 \\ .2700 & .2717 & .2734 \\ .2864 & .2880 & .2896 \\ .3017 & .3032 & .3046\end{array}$

.0040
.0695
.1270
.1639
.1928
.2172
.2385
.2576
.2751
.2911
.3061

.0050
.0774
.1313
.1671
.1954
.2194
.2405
.2595
.2767
.2927
.3075

.0060
.0846
.1354
.1702
.1980
.2217
.2425
.2613
.2784
.2942
.3089

.0070

.0000

.0911

.1393

.1732

.2005

.2239

.2445

.2030

.2800

.2957

$.0 y /$

$.14 J 1$

.1102

.2050

.2200

.2404

.2040

.2810

$.2 y /<$

.3104

.3110

. voyio

$.10<0$

.1408

$.1 / y 1$

. $\angle 050$

. 2202

. $\angle 480$

- $\angle 000$

- $<005$

. Lyol

. Jise

$\begin{array}{ccc}c & .0000 & .0100 \\ .000 & .0000 & .1082 \\ .100 & .3146 & .328 \\ .700 & .4248 & .4336 \\ .700 & .5030 & .5098 \\ .400 & .5653 & .5700 \\ .500 & .0176 & .6224 \\ .500 & .6630 & .6572 \\ .700 & .7032 & .7070 \\ .700 & .7305 & .7429 \\ .000 & .7775 & .7757\end{array}$

$\begin{array}{ll}.0200 & .0300 \\ .1504 & .1819 \\ .3409 & .3530 \\ .4422 & .4505 \\ .5165 & .5230 \\ .5764 & .5819 \\ .0272 & .0318 \\ .6714 & .6755 \\ .7108 & .7145 \\ .7463 & .7497 \\ .7788 & .7819\end{array}$

.0400
.2079
.3645
.4586
.5294
.5872
.0365
.6796
.7182
.7531
.7850
.0500
$.230 s$
.3756
.4665
.5357
.5925
.6410
.0837
.7218
.7564
.7881

.0600

.2502
.3862
.4742
.5418
.5970
.6455
.6877
.7254
.7597
.7911

.0700
.2683
.3964
.4817
.5479
.0027
.0500
.0916
.7290
.7629
.7941

.0800
$.284 y$
.4002
.4804
.5050
.0018
.0544
.6900
.7580
.7002
.7911

. uyuu

. suve .4150 $.4 y 01$ . 0590 $.01<1$ .0501 $.09 y 4$ .300 .1094 . ovuo 


$\begin{array}{ccc}C & .0000 & .1000 \\ .000 & .0000 & .3146 \\ 1.000 & .8030 & .8312 \\ .000 & 1.0231 & 1.0399 \\ 3.000 & 1.1673 & 1.1794 \\ 4.000 & 1.2759 & 1.2855 \\ 5.000 & 1.3636 & 1.3715 \\ 6.000 & 1.4372 & 1.4440 \\ 7.000 & 1.5008 & 1.5067 \\ 2.000 & 1.5567 & 1.5620 \\ 9.000 & 1.6068 & 1.6115\end{array}$

.2000
.4249
.8570
1.0560
1.1912
1.2949
1.3793
1.4506
1.5125
1.5672
1.0162

$n=1$

.3000
.5030
.8823
1.0715
1.2027
1.3040
1.3869
1.4572
1.5183
1.5723
1.6209

$\begin{array}{rr}.4000 & .5000 \\ .5653 & .6170 \\ .9056 & .9276 \\ 1.0866 & 1.1011 \\ 1.2139 & 1.2249 \\ 1.3130 & 1.3218 \\ 1.3944 & 1.4018 \\ 1.4637 & 1.4701 \\ 1.5240 & 1.5296 \\ 1.5774 & 1.5824 \\ 1.0254 & 1.0300\end{array}$

.6000
.6030
.9485
1.1151
1.2355
1.3305
1.4091
1.4764
1.5351
1.5874
1.0345

.7000
.7032
.9084
1.1288
1.2460
1.5390
1.4103
1.4820
1.5406
1.5923
1.0390

\begin{tabular}{|c|c|}
\hline .8000 & .7000 \\
\hline כצנ37. & $.11<0$ \\
\hline $.98 / 4$ & 1. UUSo \\
\hline $1.14<u$ & 1.1240 \\
\hline 1.2502 & $1 .<002$ \\
\hline $1.54 / 5$ & כככנ. 1 \\
\hline 1.4234 & $1.450 \mathrm{~s}$ \\
\hline 1.4881 & $1.4 \times 48$ \\
\hline 1.5401 & 1.0014 \\
\hline 1 . & $1.00<0$ \\
\hline 1.0454 & $1.04 / 0$ \\
\hline
\end{tabular}

$n=1$

$\begin{array}{crr}c & .0000 & 1.0000 \\ .000 & .0000 & .8030 \\ 10.000 & 1.6517 & 1.6931 \\ 20.000 & 1.9603 & 1.9826 \\ 30.000 & 2.1477 & 2.1631 \\ 40.000 & 2.2831 & 2.2948 \\ 50.000 & 2.3892 & 2.3987 \\ 60.000 & 2.4766 & 2.4845 \\ 70.000 & 2.5508 & 2.5577 \\ 80.000 & 2.6154 & 2.6214 \\ 90.000 & 2.6726 & 2.6779\end{array}$

$\begin{array}{ll}2.0000 & 3.0000 \\ 1.0231 & 1.1673 \\ 1.7312 & 1.7665 \\ 2.0039 & 2.0244 \\ 2.1779 & 2.1924 \\ 2.3062 & 2.3174 \\ 2.4080 & 2.4171 \\ 2.4924 & 2.5001 \\ 2.5544 & 2.5711 \\ 2.6274 & 2.6333 \\ 2.6832 & 2.6885\end{array}$

4.0000
1.2759
1.7994
2.0440
2.2064
2.3283
2.4200
2.5076
2.5777
2.6391
2.6937
2.0989

6.0000
1.4372
1.8591
2.0011
2.2533
2.3495
2.4435
2.5225
2.5906
2.0505
2.7039

7.0000
1.5008
1.0865
2.0980
2.2462
2.0597
2.4520
2.5297
2.5969
2.6561
2.7090

0.0000

y. uดu

1. 5001

$1.41<3$

2.1150

$<.2500$

$2.30 y 0$

2.4040

2.5Joy

2.0032

2.0011

2.7140

$1.040 \mathrm{~A}$

$1 . y .50 y$

2. 1519

<. $<>11$

L. $3 / 40$

$\angle .4005$

<. $04.5 y$

Louy.s

$2.00 / 1$

$2.110 y$

$n=1.25$

$\begin{array}{llll}C & .0000 & .0010 & .0020 \\ .000 & .0000 & .0000 & .0000 \\ .010 & .0037 & .0048 & .0060 \\ .020 & .0173 & .0189 & .0204 \\ .030 & .0333 & .0349 & .0365 \\ .040 & .0492 & .0507 & .0523 \\ .050 & .0645 & .0659 & .0674 \\ .060 & .0790 & .0804 & .0818 \\ .070 & .0927 & .0941 & .0954 \\ .020 & .1058 & .1071 & .1083 \\ .000 & .1182 & .1195 & .1207\end{array}$

.0030
.0000
.0072
.0220
.0381
.0538
.0689
.0832
.0967
.1096
.1219

$\begin{array}{ll}.0040 & .0050 \\ 0.0001 & .0003 \\ .0085 & .0099 \\ .0236 & .0252 \\ .0397 & .0413 \\ .0554 & .0569 \\ .0703 & .0718 \\ .0846 & .0859 \\ .0980 & .0993 \\ .1108 & .1121 \\ .1231 & .1242\end{array}$

.0060
.0007
.0113
.0268
.0429
.0584
.0732
.0873
.1006
.1133
.1254
.0070
.0012
.0128
.0284
.0445
.0599
.0747
.0887
.1019
.1146

.0080

.0090

.1266

.0019

.0143

.0028

.0300

.0460

.0615

.0761

.0900

.1032

.1158

.1278

n $\quad 1.25$

\begin{tabular}{|c|c|c|c|}
\hline c & . & .0100 & .0200 \\
\hline . $n \cap n$ & . & .0037 & .0173 \\
\hline $.1 \mathrm{n} 0$ & .1301 & .1415 & .1524 \\
\hline . $2 \cap n$ & . 2267 & .2347 & .2426 \\
\hline . $2 \cap n$ & . 2999 & .3053 & .3115 \\
\hline.$\Delta \cap \cap$ & .3576 & .3630 & .3682 \\
\hline . $5 \cap n$ & $.40>6$ & .4122 & .4167 \\
\hline . $A \cap \cap$ & $.451 ?$ & .4553 &.$\Delta 594$ \\
\hline החי & $.49 \cap 2$ & .4038 & .4975 \\
\hline . $2 \cap 0$ & .5254 & .5287 & .5321 \\
\hline . & .5576 & .5607 & .5638 \\
\hline
\end{tabular}

.0300
.0333
.1628
.2502
.3177
.3734
.4212
.4634
.5011
.5354
.5668

.0400
.0492
.1729
.2577
.3237
.3785
.4257
.4673
.5047
.5386
.5698

.0500
.0645
.1826
.2649
.3296
.3835
.4301
.4712
.5082
.5419
.5728

.0600
.0790
.01920
.2720
.3354
.3885
.4344
.4751
.5117
.5451
.5757

.0700
.0927
.2010
.2790
.3411
.3933
.4387
.4789
.5152
.5482
.5787

.0800
.1058
.2098
.2858
.3467
.3982
.4429
.4827
.5186
.5514
.5816

.0900

.1182 .2184 .2924 .3522 .4029 .4471 .4865 .5220 .5545 .5845 
n $\quad 1.25$

\begin{tabular}{|c|c|c|}
\hline C & .0000 & .1000 \\
\hline . $\cap \cap 0$ & . & .1301 \\
\hline $1 . \cap \cap n$ & $.52>4$ & .6150 \\
\hline >. $n$ חn & . & .8205 \\
\hline ?. & .0466 & .9587 \\
\hline$\triangle . \cap \cap O$ & $1.05 \Delta 4$ & 1.0639 \\
\hline a. $\cap n n$ & 1.1415 & 1.1494 \\
\hline a. $\cap \cap 0$ & $1.21 \Delta^{A}$ & 1.2215 \\
\hline ד. & $1.27 \times n$ & 1.2839 \\
\hline Q. . חnn & 1.3378 & 1.3391 \\
\hline Q. חחn & 1.38 .77 & 1.3884 \\
\hline
\end{tabular}

.2000
.2267
.6408
.8365
.9704
1.0732
1.1571
1.2281
1.2897
1.3442
1.3931

$\begin{array}{ll}.3000 & .4000 \\ .2989 & .3576 \\ .6651 & .6880 \\ .8519 & .8667 \\ .9818 & .9929 \\ 1.0823 & 1.0913 \\ 1.1647 & 1.1722 \\ 1.2347 & 1.2411 \\ 1.2955 & 1.3012 \\ 1.3494 & 1.3544 \\ 1.3977 & 1.4023\end{array}$

.5000
.4076
.7097
.8811
1.0038
1.1000
1.1796
1.2475
1.3068
1.3594
1.4068

.6000
.4512
.7303
.8950
1.0144
1.1086
1.1868
1.2537
1.3123
1.3644
1.4113

.7000
.4902
.7500
.9085
1.0247
1.1171
1.1940
1.2599
1.3178
1.3693
1.4158

.8000
.5254
.7687
.9216
1.0348
1.1254
1.2010
1.2661
1.3232
1.3742
1.4202

.9000

.5576

.7867

.9343

1.0448

1.1335

1.2079

1.2721

1.3285

1.3790

1.4246

\begin{tabular}{|c|c|c|}
\hline C & . $n \cap \cap 0$ & 1.0000 \\
\hline . & .0000 & .5874 \\
\hline $0.0 \cap n$ & $1.42 \% 9$ & 1.4702 \\
\hline n. 0 n & 1.7368 & 1.7591 \\
\hline n. nnn & 1.0241 & 1.9394 \\
\hline an. nnn & 2.0593 & 2.0710 \\
\hline
\end{tabular}

2.0000
.8039
1.5082
1.7804
1.9513
2.0825

$n=1.25$

$\begin{array}{rrr}3.0000 & 4.0000 & 5.0000 \\ .9466 & 1.0544 & 1.1415 \\ 1.5434 & 1.5762 & 1.0069 \\ 1.8009 & 1.8205 & 1.8393 \\ 1.9687 & 1.9827 & 1.9963 \\ 1.0936 & 2.1045 & 2.1152\end{array}$

6.0000
1.2148
1.6358
1.8575
2.0096
2.1257

7.0000

8.0000

9.0000

1.2780

1.5631

1.3338

1.3837

1.8750

2.0225

1.6890

1.7135

$1.8919 \quad 1.9083$

2.0936

2.1257

2.1359

2.1459

2.1558

$n=1.50$

\begin{tabular}{|c|c|c|}
\hline C & .0000 & .0010 \\
\hline • & חחח & .0000 \\
\hline .010 & . & .0001 \\
\hline . $n>n$ & דחח . & .0008 \\
\hline . & .0030 & .0033 \\
\hline . $n \Delta 0$ & .0069 & .0073 \\
\hline . nan & .0119 & .0125 \\
\hline . nan & .0178 & .0184 \\
\hline . 070 & .0241 & .0248 \\
\hline . חAn & .0308 & .0315 \\
\hline - non & .0376 & .0383 \\
\hline
\end{tabular}

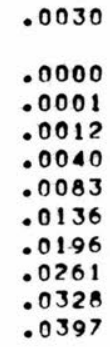

$\begin{array}{ll}.0040 & .0050 \\ .0000 & .0000 \\ .0001 & .0002 \\ .0014 & .0016 \\ .0044 & .0047 \\ .0088 & .0093 \\ .0142 & .0148 \\ .0203 & .0209 \\ .0268 & .0274 \\ .0335 & .0342 \\ .0404 & .0411\end{array}$

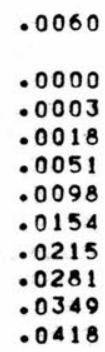

.0070
.0000
.0003
.0021
.0056
.0103
.0160
.0222
.0288
.0355
.0424

.0090

.0000

.0005

.0027

.0064

.0114

.0172

.0235

.0301

.0369

.0438 $n=1.50$

\begin{tabular}{|c|c|c|}
\hline c & . $\cap \cap \cap 0$ & .0100 \\
\hline . $\cap \cap n$ & . & .0001 \\
\hline . & .0445 & .0515 \\
\hline .200 & .1113 & .1175 \\
\hline . $3 \cap 0$ & .1692 & .1745 \\
\hline $.4 \cap 0$ & . ग10? & .2238 \\
\hline . & .2631 & .2672 \\
\hline . $a \cap n$ & $.30>4$ & .3061 \\
\hline חחד. & .3379 & .3413 \\
\hline . AnO & .3705 & .3736 \\
\hline . ann & .4005 & .0034 \\
\hline
\end{tabular}

.0200
.0007
.0584
.1236
.1798
.2284
.2713
.3098
.3447
.3766
.4062

.0400
.0069
.0721
.1356
.1900
.2374
.2793
.3170
.3513
.3827
.4119

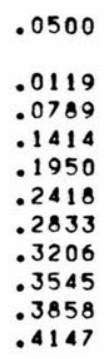

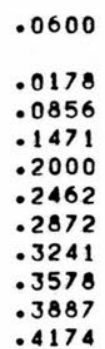

$$
\begin{aligned}
& .0700 \\
& .0241 \\
& .0922 \\
& .1528 \\
& .2049 \\
& .2505 \\
& .2910 \\
& .3276 \\
& .3610 \\
& .3917
\end{aligned}
$$$$
.4202
$$

$$
\begin{aligned}
& .0800 \\
& .0308 \\
& .0986 \\
& .1583 \\
& .2097 \\
& .2547 \\
& .2948 \\
& .3311 \\
& .3642 \\
& .3947 \\
& .4229
\end{aligned}
$$$$
.4229
$$

.0900

.0376 .1050

.1638

.2145

.2589

.2986

.3345

.3673

.3976

.4257 
n $\quad 1.50$

\begin{tabular}{|c|c|c|c|c|c|c|c|c|c|c|}
\hline C & . $\cap 0 \cap 0$ & .1000 & .2000 & .3000 & .4000 & .5000 & .6000 & .7000 & .8000 & .9000 \\
\hline ח ח & ח & .0445 & .1113 & .1692 & .2192 & .2631 & .3024 & .3379 & .3705 & .4005 \\
\hline 1. & .4284 & .4544 & .4789 & .5020 & .5239 & .5446 & .5644 & .5833 & .6014 & .0188 \\
\hline ?. คח & .0354 & .6515 & .6670 & .6819 & .6964 & .7103 & .7239 & .7371 & .7498 & .7622 \\
\hline $3.0 \cap 0$ & .7743 & .7861 & .7975 & .8087 & .8196 & .8303 & .8407 & .8508 & .8608 & .8705 \\
\hline 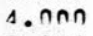 & - 8800 & .8894 & .8985 & .9075 & .9163 & .9249 & .9334 & .9417 & .9498 & .9579 \\
\hline 5. $\cap \cap \cap$ & .9658 & .9735 & .9811 & .9887 & .9960 & 1.0033 & 1.0105 & 1.0175 & 1.0245 & 1.0313 \\
\hline a. $\cap \cap n$ & $1.03 \times 1$ & 1.0447 & 1.0513 & 1.0577 & 1.0641 & 1.0704 & 1.0766 & 1.0827 & 1.0888 & 1.0948 \\
\hline 7. ח ח & 1.1007 & 1.1065 & 1.1122 & 1.1179 & 1.1235 & 1.1291 & 1.1346 & 1.1400 & 1.1454 & 1.1507 \\
\hline Q. $\cap \cap n$ & 1.1559 & 1.1611 & 1.1662 & 1.1713 & 1.1763 & 1.1813 & 1.1862 & 1.1911 & 1.1959 & 1.2007 \\
\hline ๑. $\cap \cap \cap$ & $1.2 \cap 54$ & 1.2101 & 1.2147 & 1.2193 & 1.2238 & 1.2283 & 1.2328 & 1.2372 & 1.2416 & 1.2459 \\
\hline
\end{tabular}

n 1.50

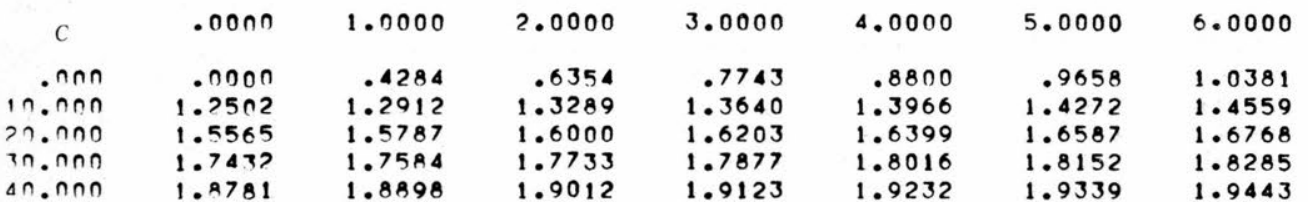

7.0000
1.1007
1.4831
1.6942
1.8414
1.9546

8. 0000

1. 1559

1. 5088

1.7111

1.8539

1.9646
9.0000

1. 2054

1.5332

1.7274

1.8662

1. 9744

n 1.75

$\begin{array}{cc}C & .0000 \\ .000 & .0001 \\ .010 & .0001 \\ .020 & .0001 \\ .030 & .0002 \\ .040 & .0006 \\ .050 & .0015 \\ .060 & .0028 \\ .070 & .0046 \\ .080 & .0068 \\ .090 & .0094\end{array}$

.0010
.0001
.0001
.0001
.0002
.0007
.0016
.0029
.0048
.0071
.0097

$\begin{array}{ll}.0020 & .0030 \\ .0001 & .0001 \\ .0001 & .0001 \\ .0001 & .0001 \\ .0003 & .0003 \\ .0007 & .0008 \\ .0017 & .0018 \\ .0031 & .0033 \\ .0050 & .0052 \\ .0073 & .0076 \\ .0100 & .0102\end{array}$
.0040
.0001
.0001
.0001
.0003
.0009
.0019
.0035
.0054
.0078
.0105

.0050

.0060

.0001

.0001

.0004

.0010

.0021

.0036

.0057

.0081

.0108

.0001

.0001

.0001

.0004

.0011

.0022

.0038

.0059

.0083

.0111

.0070
.0001
.0001
.0002
.0004
.0011
.0023
.0040
.0061
.0086
.0114

.0000

.0090

.0001

.0001

.0001

.0002

.0005

.0012

.0025

.0042

.0063

.0089

.0117

.0001

.0002

.0005

. 4013

.0026

.0044

.0000

. v0y1

.0120

. 1.75

$\begin{array}{ll}.0000 & .0100 \\ .0001 & .0001 \\ .0123 & .0154 \\ .0496 & .0537 \\ .0902 & .0942 \\ .1288 & .1325 \\ .1647 & .1681 \\ .1979 & .2011 \\ .2287 & .2316 \\ .2573 & .2601 \\ .2842 & .2868\end{array}$

$\begin{array}{ll}.0200 & .0300 \\ .0001 & .0002 \\ .0188 & .0223 \\ .0577 & .0618 \\ .0981 & .1021 \\ .1362 & .1399 \\ .1715 & .1749 \\ .2042 & .2074 \\ .2346 & .2375 \\ .2629 & .2656 \\ .2893 & .2919\end{array}$

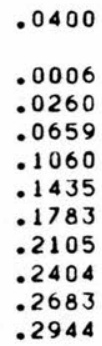

.0600
.0028
.0336
.0741
.1137
.1507
.1849
.2166
.2461
.2736
.2995

.0800
.0000
.0415
.0822
.1215
.1577
.1915
.2227
.2518
.2705
.3045

.4900

.0094

. 4455

. 4802

.1251

.1012

.1447

. 2257

- 2540

- $\angle 810$ .0009 


$\begin{array}{ccc}c & .0000 & .1000 \\ .000 & .0001 & .0123 \\ 1.000 & .3094 & .3331 \\ 2.000 & .5023 & .5176 \\ 3.000 & .6354 & .6468 \\ 4.000 & .7379 & .7470 \\ 5.000 & .8216 & .8292 \\ 6.000 & .8925 & .8990 \\ 7.000 & .8540 & .9598 \\ 8.000 & 1.0085 & 1.0136 \\ 9.000 & 1.0573 & 1.0619\end{array}$

$\begin{array}{ll} & n=1.75 \\ .2000 & .3000 \\ .0496 & .0902 \\ .3556 & .3770 \\ .5323 & .5466 \\ .6579 & .6687 \\ .7559 & .7647 \\ .8367 & .8440 \\ .9055 & .9118 \\ .9654 & .9710 \\ 1.0187 & 1.0237 \\ 1.0665 & 1.0710\end{array}$

.4000
.1288
.3973
.5605
.6793
.7733
.8513
.9181
.9766
1.0286
1.0755

.5000
.1647
.4167
.5739
.6896
.7817
.8584
.9243
.9820
1.0335
1.0800

.6000
.1979
.4352
.5869
.6997
.7900
.8654
.9304
.9874
1.0384
1.0844
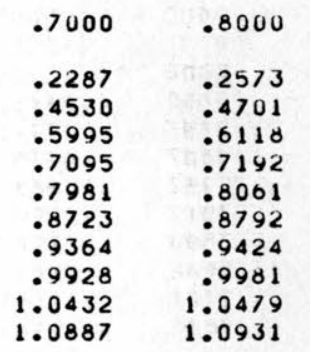

.9000

.2842 .4805 .0238 .7287 .0139 .8859 .9482 1.0035 1.0526 1. 4974

$\begin{array}{crrr}c & .0000 & 1.0000 & 2.0000 \\ .000 & .0001 & .3094 & .5023 \\ 10.000 & 1.1016 & 1.1422 & 1.1796 \\ 20.000 & 1.4056 & 1.4277 & 1.4489 \\ 30.000 & 1.5917 & 1.6070 & 1.6218 \\ 40.000 & 1.7267 & 1.7384 & 1.7499 \\ 50.000 & 1.8331 & 1.8427 & 1.8520 \\ 60.000 & 1.9212 & 1.9292 & 1.9372 \\ 70.000 & 1.9966 & 2.0036 & 2.0104 \\ 80.000 & 2.0626 & 2.0688 & 2.0749 \\ 90.000 & 2.1215 & 2.1270 & 2.1325\end{array}$

3.0000
.6354
1.2143
1.4691
1.6362
1.7611
1.8612
1.9450
2.0172
2.0809
2.1380

4.0000
.7379
1.2466
1.4886
1.6502
1.7720
1.8702
1.9527
2.0240
2.0869
2.1433

$\begin{array}{rr}5.0000 \% & 6.0000 \\ & \\ .8216 & .8925 \\ 1.2770 & 1.3056 \\ 1.5074 & 1.5254 \\ 1.6638 & 1.6770 \\ 1.7827 & 1.7932 \\ 1.8790 & 1.8878 \\ 1.9602 & 1.9677 \\ 2.0306 & 2.0372 \\ 2.0928 & 2.0987 \\ 2.1487 & 2.1540\end{array}$

7.0000

.9540
1.3326
1.5428
1.6899
1.8035
1.8963
1.9751
2.0436
2.1045
2.1592
8.0000
1.0085
1.3581
1.5597
1.7025
1.8136
1.9047
1.9823
2.0500
2.1102
2.1644

9.0000

\subsection{3}

1.3824

1.5759

1.1140

1.0254

1. 1130

1.9895

2.0564

2.1159

2.1695

$\begin{array}{cc}C & .0000 \\ .000 & .0000 \\ .100 & .0027 \\ .200 & .0198 \\ .300 & .0449 \\ .400 & .0722 \\ .500 & .0994 \\ .600 & .1259 \\ .700 & .1512 \\ .800 & .1754 \\ .900 & .1985\end{array}$

.0100
.0001
.0037
.0221
.0476
.0749
.1021
.1285
.1537
.1778
.2007

.0200
.0001
.0050
.0244
.0503
.0777
.1048
.1310
.1562
.1801
.2030

$n=2$

.0300
.0001
.0064
.0269
.0530
.0804
.1075
.1336
.1586
.1824
.2052
.0400
.0001
.0079
.0293
.0557
.0832
.1101
.1362
.1610
.1848

.0500

.0600

.0700

.0800

.0900

.0002

.0003

.0318

.0585

.0859

.1128

.1387

.1635

.1871

.0115

.0006

.0134

.0370

.0639

.0913

.0612

.1154

.1412

.1659

.1181

.1437

.1683

.1917

.1894
.2118

.2140

.0011

.0154

.0396

.0667

.0940

.1207

.1462

.1707

1039

.2101

.0018 .0170 .0422 .0694 .0967 .1233

.1487

.1730

.1962

.2183

$\begin{array}{ccccc}c & .0000 & .1000 & .2000 & .3000 \\ .000 & .0000 & .0027 & .0198 & .0449 \\ 1.000 & .2205 & .2414 & .2615 & .2807 \\ 2.000 & .3960 & .4103 & .4241 & .4375 \\ 3.000 & .5218 & .5326 & .5432 & .5535 \\ 4.000 & .6201 & .6289 & .6375 & .6459 \\ 5.000 & .7011 & .7085 & .7158 & .7229 \\ 6.000 & .7701 & .7765 & .7828 & .7890 \\ 7.000 & .8303 & .8359 & .8414 & .8469 \\ 8.000 & .8836 & .8887 & .8936 & .8985 \\ 9.000 & .9316 & .9362 & .9407 & .9451\end{array}$

.4000
.0722
.2991
.4506
.5637
.6542
.7300
.7951
.8523
.9034
.9495

.5000
.0994
.3168
.4632
.5736
.6624
.7369
.8012
.8577
.9082
.9539

.6000
.1259
.3338
.4756
.5833
.6704
.7437
.8071
.8630
.9130
.9582

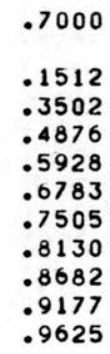
.8000
.1754
.3660
.4993
.7571

.9000

.1985

.3812

.0106

.0112

.0936

.7637

.8246

.0786

.9270

.9710 


$\begin{array}{cr}c & .0000 \\ 10.000 & .0000 \\ 20.000 & .9752 \\ 30.000 & 1.2758 \\ 40.000 & 1.4607 \\ 50.000 & 1.5952 \\ 60.000 & 1.7012 \\ 70.000 & 1.8642 \\ 80.000 & 1.9301 \\ 90.000 & 1.9888\end{array}$

1.0000

.2205
1.0152
1.2978
1.4759
1.6068
1.7107
1.7970
1.8712
1.9363
1.9944

2.0000

.3960
1.0521
1.3188
1.4907
1.6182
1.7200
1.8049
1.8780
1.9424
1.9999

$n=2$

$\begin{array}{ccc}C & .0000 & .0100 \\ .000 & .0000 & .0000 \\ .100 & .0000 & .0000 \\ .200 & .0000 & .0000 \\ .300 & .0000 & .0000 \\ .400 & .0001 & .0001 \\ .500 & .0003 & .0004 \\ .600 & .0009 & .0010 \\ .700 & .0019 & .0020 \\ .800: & .0033 & .0034 \\ .000 & .0051 & .0053\end{array}$

$\begin{array}{ll}.0200 & .0300 \\ .0000 & .0000 \\ .0000 & .0000 \\ .0000 & .0000 \\ .0000 & .0000 \\ .0001 & .0001 \\ .0004 & .0005 \\ .0011 & .0012 \\ .0021 & .0022 \\ .0036 & .0038 \\ .0055 & .0057\end{array}$

.0400
.0000
.0000
.0000
.0000
.0002
.0005
.0012
.0024
.0039
.0059

.0500
.0000
.0000
.0000
.0000
.0002
.0006
.0013
.0025
.0041
.0062

.0600
.0000
.0000
.0000
.0000
.0082
.0006
.0014
.0027
.0043
.0004

.0700
.0000
.0000
.0000
.0000
.0002
.0007
.0015
.0028
.0045
.0066
.0800
.0000
.0000
.0000
.0001
.0003
.0008
.0016
.0030
.0047
.0069

.0900

$n=4$

$\begin{array}{ccc}c & .0000 & .1000 \\ .000 & .0000 & .0000 \\ 1.000 & .0073 & .0100 \\ 2.000 & .0457 & .0505 \\ 3.000 & .0957 & .1008 \\ 4.000 & .1462 & .1511 \\ 5.000 & .1942 & .1988 \\ 6.000 & .2390 & .2433 \\ 7.000 & .2806 & .2846 \\ 8.000 & .3193 & .3230 \\ 9.000 & .3553 & .3588\end{array}$

$\begin{array}{ll}.2000 & .3000 \\ .0000 & .0000 \\ .0130 & .0163 \\ .0554 & .0603 \\ .1059 & .1110 \\ .1560 & .1609 \\ .2034 & .2080 \\ .2475 & .2518 \\ .2885 & .2925 \\ .3267 & .3303 \\ .3623 & .3657\end{array}$

.4000
.0001
.0199
.0653
.1161
.1658
.2125
.2560
.2964
.3340
.3691

.5000
.0003
.0238
.0703
.1212
.1706
.2170
.2601
.3003
.3376
.3725
.6000
.0009
.0278
.0753
.1262
.1754
.2214
.2043
.3041
.3412
.3758

.7000
.0019
.0321
.0804
.1312
.1801
.2259
.2684
.3079
.3448
.3792

.8000

.9000

.0033

.0051

.0365

.0411

$.0850 \quad .0900$

$.1363 \quad .1412$

$.1848 \quad .1845$

$.2305 \quad .2346$

$.2725 \quad .2765$

.3117 .J155

.3403 .0518

$.3825 \quad .3858$ 


\begin{tabular}{|c|c|c|c|c|c|}
\hline \multirow[b]{2}{*}{ C } & \multirow[b]{2}{*}{.0000} & \multicolumn{4}{|c|}{$n=6$} \\
\hline & & .1000 & .2000 & .3000 & .4000 \\
\hline $\begin{array}{r}.000 \\
1.000 \\
2.000 \\
3.000 \\
4.000 \\
5.000 \\
6.000 \\
7.000 \\
8.000 \\
9.000\end{array}$ & $\begin{array}{l}.0000 \\
.0001 \\
.0027 \\
.0118 \\
.0266 \\
.0448 \\
.0650 \\
.0861 \\
.1076 \\
.1290\end{array}$ & $\begin{array}{l}.0000 \\
.0001 \\
.0033 \\
.0131 \\
.0283 \\
.0468 \\
.0671 \\
.0883 \\
.1097 \\
.1311\end{array}$ & $\begin{array}{l}.0000 \\
.0002 \\
.0040 \\
.01144 \\
.0300 \\
.0487 \\
.0692 \\
.0904 \\
.1119 \\
.1332\end{array}$ & $\begin{array}{l}.0000 \\
.0003 \\
.0047 \\
.0158 \\
.0317 \\
.0507 \\
.0713 \\
.0925 \\
.1140 \\
.1353\end{array}$ & $\begin{array}{l}.0000 \\
.0005 \\
.0056 \\
.0172 \\
.0335 \\
.0527 \\
.0734 \\
.0947 \\
.11161 \\
.1374\end{array}$ \\
\hline
\end{tabular}

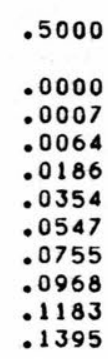

$n=6$

$\begin{array}{cc}C & .0000 \\ .000 & .0000 \\ 10.000 & .1500 \\ 20.000 & .3330 \\ 30.000 & .4710 \\ 40.000 & .5799 \\ 50.000 & .6695 \\ 60.000 & .7457 \\ 70.000 & .8118 \\ 80.000 & .8704 \\ 90.000 & .9228\end{array}$

1.0000
.0001
.1707
.3485
.4829
.5896
.6777
.7527
.8180
.8758
.9278

$\begin{array}{ll}4.0000 & 5.0000 \\ .0266 & .0448 \\ .2296 & .2481 \\ .3925 & .4065 \\ .5173 & .5283 \\ .6176 & .6267 \\ .7014 & .7090 \\ .7732 & .7798 \\ .8361 & .8419 \\ .8920 & .8973 \\ .9424 & .9472\end{array}$

$$
\begin{aligned}
& .0000 \\
& .0000 \\
& .0010 \\
& .0074 \\
& .0201 \\
& .0372 \\
& .0568 \\
& .0776 \\
& .0990 \\
& .1204 \\
& .1417
\end{aligned}
$$

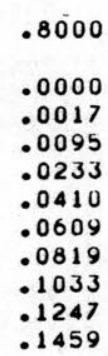
7.0000
.0861
. 2836
.4332
.5495
.6442
.7240
.7929
.8535
.9076
.9566

3.0000
.0118
.2105
.3783
.5061
.6085
.6936
.7664
.8301
.8867
.9376

.0000
.0650
.2661
.4200
.5390
.6355
.7166
.7864
.8477
.9025
.9519

$\begin{array}{ll}8.0000 & 9.0000 \\ .1076 & .1290 \\ .3005 & .5170 \\ .4401 & .4587 \\ .5599 & .5700 \\ .6528 & .0612 \\ .7313 & .7385 \\ .7993 & .8056 \\ .8592 & .8048 \\ .9128 & .4178 \\ .9612 & .9659\end{array}$

$-8$

$\begin{array}{ll}.2000 & .0000 \\ .0000 & .0000 \\ .0000 & .0000 \\ .0001 & .0002 \\ .0012 & .0014 \\ .0041 & .0045 \\ .0090 & .0096 \\ .0157 & .0165 \\ .0239 & .0248 \\ .0333 & .0343 \\ .0435 & .0445\end{array}$

.5000
.0000
.0000
.0003
.0019
.0054
.0109
.0180
.0260
.0363
.0467

.0000
.0000
.0000
.0004
.0021
.0058
.0115
.0188
.0275
.0373
.0477
.7000
.0000
.0000
.0005
.0024
.0063
.0122
.0197
.0285
.0383
.0488

$$
\begin{aligned}
& .8000 \\
& .0000 \\
& .0000 \\
& .0000 \\
& .0027 \\
& .0068 \\
& .0120 \\
& .0205 \\
& .0294 \\
& .0393 \\
& .0499
\end{aligned}
$$$$
.0499
$$

.9000

.0000

.0001

- v0u7

- voso

.0073

- 0135

.0213

.0304

.0403

.0510

.9000
.0000
.0022
.0106
.0249
.0429
.0629
.0840
.1054
.1268
.1480

$n=8$

$\begin{array}{ll}2.0000 & 3.0000 \\ .0001 & .0009 \\ .0748 & .0865 \\ .1906 & .2016 \\ .2928 & .3022 \\ .3799 & .3879 \\ .4549 & .4618 \\ .5205 & .5266 \\ .5786 & .5841 \\ .6309 & .6358 \\ .6783 & .6828\end{array}$

4.0000
.0034
.0982
.2124
.3114
.3958
.4687
.5326
.5895
.6407
.6872

$$
\begin{array}{r}
5.0000 \\
.0079 \\
.1101 \\
.2230 \\
.3204 \\
.4035 \\
.4754 \\
.5386 \\
.5949 \\
.6456 \\
.6917
\end{array}
$$

$\begin{array}{ll}6.0000 & 7.0000 \\ .0143 & .0222 \\ .1219 & .1336 \\ .2335 & .2438 \\ .3293 & .3381 \\ .4112 & .4187 \\ .4821 & .4887 \\ .5445 & .5504 \\ .6002 & .6054 \\ .6504 & .6551 \\ .6961 & .7004\end{array}$

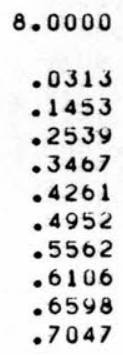

9.0000
.0414
.1508
.2639
.0552
.4355
.0016
.0619
.0158
.0645
.1090


n-10

\begin{tabular}{|c|c|c|c|c|c|c|c|c|c|c|}
\hline c & .0000 & .1000 & .2000 & .3000 & .4000 & .5000 & .6000 & .7000 & .8000 & .4000 \\
\hline $\begin{array}{l}1.000 \\
2.000\end{array}$ & $\begin{array}{l}.0000 \\
.0000\end{array}$ & $\begin{array}{l}.0000 \\
.0000\end{array}$ & $\begin{array}{l}.0000 \\
.0000\end{array}$ & $\begin{array}{l}.0000 \\
.0000\end{array}$ & $\begin{array}{l}.0000 \\
.0000\end{array}$ & .0000 & .0000 & .0000 & .0000 & .0000 \\
\hline 3.000 & .0000 & .0000 & .0000 & .0001 & .0001 & .0001 & .0001 & .0002 & .0002 & .0002 \\
\hline 4.000 & .0003 & .0003 & .0004 & .0004 & .0005 & .0006 & .0006 & .0007 & .0000 & .0009 \\
\hline 5.000 & .0010 & .0011 & .0012 & .0013 & .0015 & .0016 & .0018 & .0019 & .0021 & .0022 \\
\hline 6.000 & .0024 & .0026 & .0028 & .0030 & .0032 & .0034 & .0036 & .0039 & .0041 & .0044 \\
\hline 7.000 & .0046 & .0049 & .0052 & .0054 & .0057 & .0060 & .0063 & .0066 & .0070 & .4073 \\
\hline 8.000 & .0076 & .0080 & .0083 & .0087 & .0090 & .0094 & .0098 & .0102 & .0100 & .0110 \\
\hline 9.000 & .0114 & .0118 & .0122 & .0126 & .0131 & .0135 & .0140 & .0144 & $.014 y$ & .0155 \\
\hline
\end{tabular}

10

\begin{tabular}{|c|c|c|c|c|c|c|c|c|c|c|}
\hline C & .0000 & 1.0000 & 2.0000 & 3.0000 & 4.0000 & 5.0000 & 6.0000 & 7.0000 & 8.0000 & 9.0000 \\
\hline .000 & .0000 & .0000 & .0000 & .0000 & .0003 & .0010 & .0024 & .0046 & .0010 & .0114 \\
\hline 10.000 & .0158 & .0208 & .0263 & .0323 & .0386 & .0452 & .0520 & .0590 & .0002 & . \\
\hline 20.000 & .0808 & .0883 & .0957 & .1032 & .1107 & .1182 & .1257 & .1332 & .1400 & .1474 \\
\hline 30.000 & .1553 & .1625 & .1698 & .1769 & .1840 & .1911 & .1981 & .2050 & .2110 &.$\angle 100$ \\
\hline 40.000 & .2253 & .2320 & .2386 & .2451 & .2516 & .2579 & .2643 & .2705 & $.270 \%$ & $. \angle 8<y$ \\
\hline 50.000 & .2889 & .2949 & .3009 & .3068 & .3126 & .3184 & .3241 & .3297 & .3353 & צOSOS. \\
\hline 60.000 & .3464 & .3518 & .3572 & .3625 & .3678 & .3730 & .3782 & .3833 & .3884 & .3934 \\
\hline 70.000 & .3984 & .4034 & .4083 & .4131 & .4179 & .4227 & .4274 & .4321 & .4308 & .4414 \\
\hline 80.000 & .4459 & .4504 & .4549 & .4594 & .4638 & .4682 & .4725 & .4768 & .4811 & .4853 \\
\hline 90.000 & .4895 & .4937 & .4978 & .5019 & .5060 & .5100 & .5140 & .5180 & .5214 & .5250 \\
\hline
\end{tabular}


Table AII. Heat flux vs warmup time.

$$
\begin{array}{rlrl}
k=1.7 \mathrm{Btu} / \mathrm{ft} \mathrm{hr}{ }^{\circ} \mathrm{F} & C=0.19 \mathrm{Btu} / \mathrm{lb}{ }^{\circ} \mathrm{F} & \begin{array}{l}
a=0.050 \mathrm{ft}^{2} / \mathrm{hr} \\
\mathrm{a}=7.33 \mathrm{ft}
\end{array} \\
r / a=1 \text { (surface) } & \frac{\Delta T k}{\mathrm{a} \phi}=f\left(\frac{a t}{\mathrm{a}^{2}}\right) & \frac{35.3}{\phi}=f\left(0.0224 t^{\prime}\right) ; t^{\prime} \text { in days }
\end{array}
$$

\begin{tabular}{cccc}
$\begin{array}{c}\text { Heat flux, } \\
\left(B t u / f t^{2} h r\right)\end{array}$ & $\frac{35.3}{\phi}$ & $\mathrm{f}\left(0.0224 \mathrm{t}^{\prime}\right)^{*}$ & $\mathrm{t}^{\prime}$ (days) \\
\hline 30 & 1.177 & 3.10 & 138 \\
40 & .883 & 1.30 & 58.0 \\
50 & .706 & .70 & 31.2 \\
60 & .589 & .45 & 20.1 \\
70 & .505 & .30 & 13.4 \\
80 & .441 & .22 & 9.8 \\
90 & .392 & .166 & 7.4 \\
100 & .353 & .130 & 5.8 \\
\hline
\end{tabular}

* Values obtained from Table AI.

Table AIII. Surface temperature vs time.
$k=1.7$
$c=0.19$
$a=0.050$
$a=7.33$
$\rho=177$
$\phi=60$
$r / a=1 \quad \frac{\Delta T k}{a \phi}=f\left(\frac{a t}{a^{2}}\right) \quad \Delta T=259 \mathrm{f}\left(0.0224 t^{\prime}\right) ; t^{\prime}$ in days

\begin{tabular}{ccccc}
$\mathrm{t}^{\prime}$ & $0.0224 \mathrm{t}^{\prime}$ & $\mathrm{f}\left(0.0224 \mathrm{t}^{\prime}\right)$ & $\Delta \mathrm{T}$ & $* \mathrm{~T}_{\mathrm{s}}=60+\mathrm{T}$ \\
\hline 0.1 & 0.00224 & 0.0523 & $13.5^{\circ} \mathrm{F}$ & $73.5^{\circ} \mathrm{F}$ \\
1 & 0.0224 & 0.1587 & 41.1 & 101.1 \\
2 & 0.0448 & 0.2189 & 56.7 & 116.7 \\
4 & 0.0896 & 0.2996 & 77.5 & 137.5 \\
8 & 0.1792 & 0.3954 & 102.3 & 162.3 \\
12 & 0.2688 & 0.4808 & 124.8 & 184.8 \\
15 & 0.3360 & 0.5268 & 136.5 & 196.5 \\
20 & 0.4490 & 0.5920 & 153.0 & 213.0 \\
\hline
\end{tabular}

\footnotetext{
${ }^{*} T_{S}=$ rock surface temperature.
} 
DOCUMENT CONTROL DATA - R \& D

Security classification of title, body of abstract and indexing annotation must be ontered when the overall report is classified)

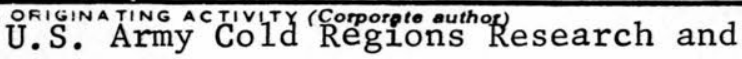

Engineering Laboratory

Hanover, New Hampshire

3. REPORT TITLE

FIELD TEST OF A STEAM CONDENSER HEAT SINK CONCEPT

4. OESCRIPTIVE NOTES (TyPe of roport and inclusive dates)

5. AU THOR(S) (First name, middle initial, last name)

W.F. Quinn, H.W.C. Aamot and M.M. Greenberg

\begin{tabular}{|c|c|c|}
\hline $\begin{array}{l}\text { O. REPORT DATE } \\
\text { January } 1974\end{array}$ & $\begin{array}{l}\text { 7a. TOTAL NO. OFPAGES } \\
49\end{array}$ & $\begin{array}{c}\text { 7b. NO. OF REFS } \\
17\end{array}$ \\
\hline 8A. ONTRACT OR GRAINTNO. & \multicolumn{2}{|c|}{ 9a. ORIGINATOR'S REPORT NIUMBER(S) } \\
\hline b. WEIJECT NO. & \multicolumn{2}{|c|}{ Special Report 199} \\
\hline $\begin{array}{l}\text { c. } \\
\text { c. }\end{array}$ & \multicolumn{2}{|c|}{$\begin{array}{l}\text { Db. OTHER REPORT NO(S) (Any other numbers that may bo assienod } \\
\text { this roport) }\end{array}$} \\
\hline
\end{tabular}

Approved for public release; distribution unlimited.

\begin{tabular}{l|l}
\hline 1. SUPPLEMENTARY NOTES & 'i2 SPONSORING MILITARYACTIVITY \\
& U.S. Army Engineer Reactors Group \\
Nuclear Power Division & office, Chief of Engineers
\end{tabular}

A concept to reject heat generated by an underground power plant by disposal of exhaust steam to rock tunnels was evaluated by means of a field test. The tunnel walls would, thus, be used to condense the steam and store the heat under a transient heating load. Heat transfer to the rock was initia11y predicted using the well-known Carslaw and Jaeger analytical model which considers the test tunnel to be represented by a hollow cylinder in an infinite medium initially at a constant temperature. Information was developed ragarding the heat transfer coefficient associated with the condensation of steam on rock. Establishing a comparison between the measured and predicted temperatures was complicated by the problem of rock fall which retarded the rate of temperature rise. The writers feel that meaningful comparisons are valid for the first few days of the test, prior to any substantial rock fall.

14. KEY WORDS

Cooling

Cooling systems

Electric power plants

Heat sinks 